\title{
GERAÇÃO DA SÉRIE HISTÓRICA DE VAZÃO POR MEIO DO MODELO SMAP: SUBSÍDIO PARA O PLANO DE MANEJO DA BACIA DO RIO GRANDE DE UBATUBA.
}

\author{
ViVIANE COELHO BUCHIANERI
}

Dissertação apresentada à Escola Superior de Agricultura "Luiz de Queiroz", Universidade de São Paulo, para obtenção de titulo de mestre em Recursos Florestais, Área de Concentração: Conservação de Ecossistemas.

P I R A C I C A B A

Estado de São Paulo - Brasil

Fevereiro -2004 


\title{
GERAÇÃO DA SÉRIE HISTÓRICA DE VAZÃO POR MEIO DO MODELO SMAP: SUBSÍDIO PARA O PLANO DE MANEJO DA BACIA DO RIO GRANDE DE UBATUBA.
}

\author{
VIVIANE COELHO BUCHIANERI \\ Engenheiro Agrônomo \\ Orientador: Prof. Dr. WALTER DE PAULA LIMA
}

Dissertação apresentada à Escola Superior de Agricultura "Luiz de Queiroz", Universidade de São Paulo, para obtenção de titulo de mestre em Recursos Florestais, Área de Concentração: Conservação de Ecossistemas.

PIRACICABA

Estado de São Paulo - Brasil

Fevereiro - 2004 


\section{Dados Internacionais de Catalogação na Publicação (CIP) DIVISÃO DE BIBLIOTECA E DOCUMENTAÇÃO - ESALQ/USP}

\section{Buchianeri, Viviane Coelho}

Geração da série histórica de vazão por meio do modelo SMAP: subsídio para o plano de manejo da bacia do Rio Grande de Ubatuba / Viviane Coelho Buchianeri. - Piracicaba, 2004

105 p. : il.

Dissertação (mestrado) - - Escola Superior de Agricultura Luiz de Queiroz, 2004.

Bibliografia.

1. Abastecimento de água 2. Análise de série temporal 3. Bacia hidrográfica (manejo) Balanço hídrico 5. Ecossistema (conservação) 6. Manancial 7. Vazão I. Título

CDD 333.91

\section{"Permitida a cópia total ou parcial deste documento, desde que citada a fonte - O autor"}


Aos meus filhos Rodrigo e Thiago, razão de minha existência, dedico esse trabalho na intenção de compensar minha ausência em muitos momentos e como forma de registrar o imenso amor que sinto por eles.

Ao meu marido, Bepo, com quem compartilho minhas emoções e minha vida.

"Cada um de nós compõe a sua história, cada ser, em si, carrega o dom de ser capaz e ser feliz". Todo mundo anda, todo mundo chora, um dia a gente chega e o outro vai embora...

Penso que cumprir a vida seja, simplesmente, compreender a marcha, ir seguindo em frente... Hoje me sinto mais forte, mais feliz. Só levo a certeza de que muito pouco sei, ...eu nada sei”. 


\section{AGRADECIMENTOS}

Ao Professor Dr. Walter de Paula Lima, por sua orientação e dedicação na condução da pesquisa;

À Dra. Maria José Zakia por sua co-orientação, pela dedicação, paciência, e disposição sem limite, e antes de tudo pela oportunidade de conhecer e compartilhar momentos especiais com uma pessoa tão genial.

Ao Eng. João Eduardo Lopes por oferecer seus ensinamentos para trabalhar com o modelo SMAP;

Ao Eng. Fernando da TRN pela digitalização dos mapas da bacia e ao Cleber pelas ilustrações da estrutura do modelo SMAP e do ciclo hidrológico ;

Ao Chris Neiel pelo auxílio nas correções e traduções dos trabalhos científicos;

Ao Departamento de Ciências Florestais, que possibilitou a realização do curso de pós-graduação;

Ao Laboratório de Hidrologia, em especial a Paula pela ajuda na digitação do texto, e na formatação dos gráficos e tabelas e ainda por socorrer em muitos momentos difíceis; 
Ao Instituto Florestal pela oportunidade de realizar esta capacitação e em especial, ao Eng. Valdir de Cicco por me incentivar a iniciar meus estudos em hidrologia florestal;

Ao Projeto de Preservação da Mata Atlântica e em especial, à Coordenadora Ciça pelo apoio integral e pela oportunidade de divulgação da pesquisa.

Ao Comitê de Bacia Hidrográfica do Litoral Norte, e, em especial a Rosa e; também aos participantes do Grupo de Trabalho do Rio Grande pelo apoio no desenvolvimento da pesquisa.

Aos meus tios Nena e Carlos pela hospitalidade, brincadeiras e apoio integral;

A lara, que sempre esteve disposta em oferecer ajuda nos momentos que tive que me dedicar à pesquisa e a minha grande amiga Zaira que apesar da distancia sempre teve presente incentivando e agüentando minhas lamentações;

Aos meus colegas Carla, Noemi, Lucia, Cláudia, Raquel, Renata, Mônica e Klaus pela convivência descontraída e pelas trocas valiosas de informações.

A Tiana e Rosana que sempre com muito bom humor, ajudaram a cuidar dos meus filhos nos momentos que me dediquei à pesquisa.

E finalmente, e não menos importante, agradecimento ao meu pai Plácido (em memória), a Marzé, a Laís,a D. Dulce, meus irmãos, cunhados e sobrinhos e, ao Treck Jones. A oportunidade de conviver ou ter convivido com vocês sempre fez e faz meu viver mais suave e feliz. 


\section{SUMÁRIO}

Página

LISTA DE FIGURAS....................................................................... viii

LISTA DE TABELAS .....................................................................

LISTA DE QUADROS................................................................ xii

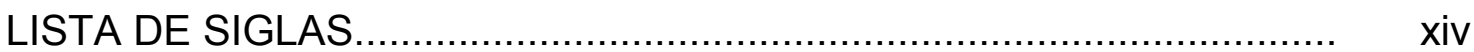

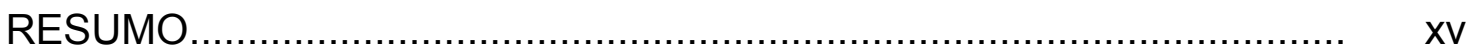

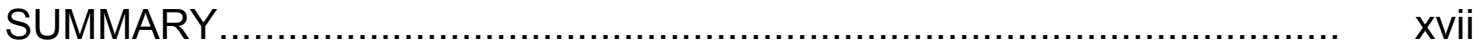

1 INTRODUÇÃO. ............................................................. 1

2 A CONTEXTUALIZAÇÃO ATUAL DO PROJETO DE PESQUISA PARTICIPATIVA ................................................................ 4

3 REVISÃO DA LITERATURA .............................................. 17

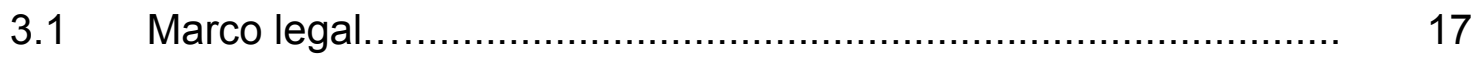

3.2 Fundamentos teóricos: A importância da floresta na produção de água ............................................................... 18

3.2.1 O ciclo hidrológico e a bacia hidrográfica...................................... 18

3.2.2 A influência da floresta na produção de água............................... 21

3.2.3 Modelos hidrológicos........................................................... 33

$4 \quad$ MATERIAIS E MÉTODOS .................................................. 39

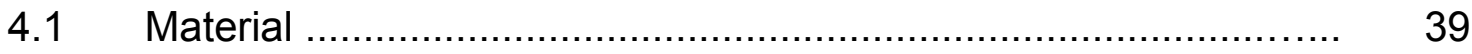

4.1.1 Caracterização geral da bacia do Rio Grande............................. 39

4.1.2 Uso do solo....................................................................... 43

4.1.3 Censo e a taxa de crescimento populacional do município de

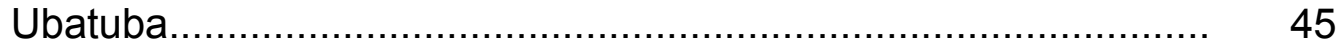

4.2 Método........................................................................ 46 
4.2.1 A delimitação da bacia.......................................................... 46

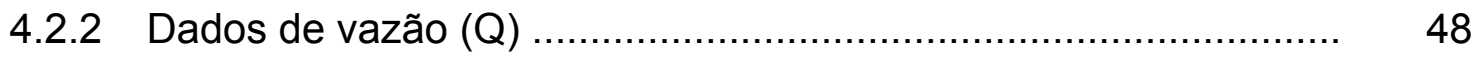

4.2.3 Precipitação.......................................................................... 48

4.2.4 Evapotranspiração (ETP) ................................................. 51

4.2.5 Modelo SMAP ....................................................................... 55

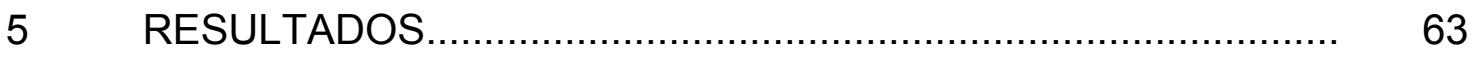

5.1 Calibração do modelo SMAP para a bacia do Rio Grande de

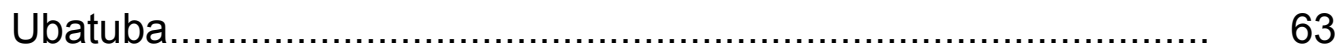

5.2 Validação dos parâmetros da bacia do rio Grande........................ 68

5.3 Geração da série histórica........................................................... 72

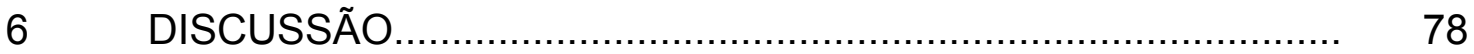

6.1 Vazão ecológica.................................................................. 78

6.2 Balanço entre disponibilidade $x$ demanda.................................. 80

6.3 Sazonalidade da população......................................................... 86

$7 \quad$ CONCLUSÕES....................................................... 93

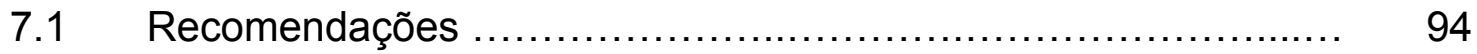

REFERÊNCIAS BIBLIOGRÁFICAS................................... 96 


\section{LISTA DE FIGURAS}

Página

1 Painel de identificação dos problemas............................................ 10

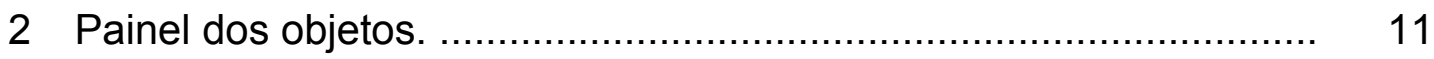

3 Matriz de planejamento - Quantidade e qualidade da água (em destaque a atividade contemplada no presente trabalho)................. 13

4 Matriz de planejamento - proteção, conservação e geração de

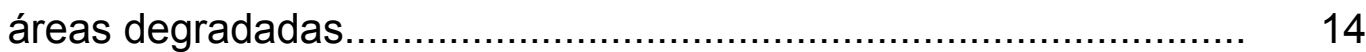

5 Matriz de planejamento - Gestão …………............................... 15

6 Matriz de planejamento - Divulgação, capacitação e conscientização ambiental........................................................ 16

7 Esquema do ciclo hidrológico........................................................ 20

8 Principais componentes do ciclo hidrológico em uma bacia hidrográfica (Zakia, 2000)........................................................ 22

9 Esquema dos processos hidrológicos em uma floresta (Adaptado de Lima,1993).............................................................. 23

10 Visualização do conceito de "área variável de afluência" (AVA) na geração do deflúvio em microbacias (Hewlett \& Hibbertt 1967)

11 Classificação de modelos hidrológicos (Passos, 1993)

12 Localização do município de Ubatuba com destaque para a bacia do Rio Grande ( IBGE, 1981).

13 Mapa da cobertura florestal na bacia do Rio Grande (Fonte TRN). 
14 Delimitação da bacia do Rio Grande de Ubatuba sobre a base cartográfica 1:10.000 do Estado de São Paulo...............................

15 Foto do ponto de captação de água na bacia do Rio Grande de Ubatuba.

16 Comparação entre a ETP mensal $(\mathrm{mm})$ calculada em Ubatuba pelo método THORNTHWAITE (1948) com o Tanque Classe A de

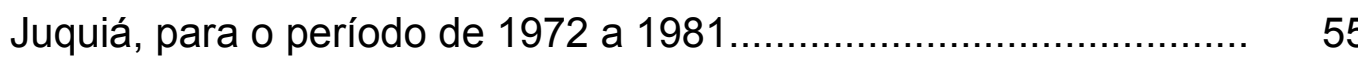

17 Ilustração da estrutura do Modelo SMAP na versão mensal............ 56

18 Tela de abertura do programa SMAP ........................................... 64

19 Tela do programa SMAP, após calibração automática...................... 65

20 Tela de resultado após os primeiros ajustes manuais...................... 66

21 Relação Chuva-Vazão calculada e vazão observada, para dois anos hídricos, na fase de calibração do Modelo SMAP.................... 68

22 Relação Chuva-Vazão calculada e vazão observada, para os quatro anos hídricos, na fase de validação do Modelo SMAP.

23 Série histórica para a relação Chuva-Vazão gerada pelo Modelo SMAP, para o período de agosto de 1935 a julho de 2001.

24 Demanda de água atual na bacia e disponibilidade de água considerando as vazões medias na série histórica para o período de 1935 a 2001

25 Demanda de água atual na bacia e disponibilidade de água considerando as vazões medias no ano hídrico mais seco (19551956) encontrada na série histórica gerada para o período de 1935 a 2001.

26 Demanda de água atual na bacia e disponibilidade de água considerando as vazões medias no ano hídrico mais chuvoso (1966-1967) encontrado na série histórica gerada para o período de 1935 a 2001 
27 Meses com vazão excedente ou com déficit hídrico para o período

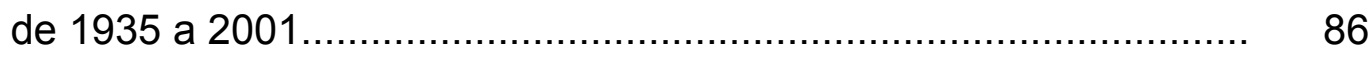




\section{LISTA DE TABELAS}

Página

1 Série de vazão média mensal $\left(\mathrm{m}^{3} / \mathrm{s}\right)$ monitorada pelo DAEE de 48 1972 a 1975.

2 Total de chuva mensal $(\mathrm{mm})$ no período de 1935 - 2001. Instituto Agronômico - Seção de Climatologia Agrícola da Estação Experimental de Ubatuba.

3 Temperatura média $[\mathrm{Max}+\mathrm{Min}] / 2\left({ }^{\circ} \mathrm{C}\right)$ no período de $1935-2001$. Instituto Agronômico - Seção de Climatologia Agrícola da Estação Experimental de Ubatuba.

4 ETP calculado pelo método Thornthwaite \& Matter na Bacia do Rio Grande e dados do Tanque Classe A da Bacia de Juquiá.

5 Série gerada de vazões médias mensais $\left(\mathrm{m}^{3} / \mathrm{s}\right)$ para o Rio Grande de Ubatuba (1935 a 2001) 


\section{LISTA DE QUADROS}

Página

1 Estrutura de entrada de dados do Modelo SMAP na versão mensal (Para calibração e validação do modelo)......................................... 60

2 Estrutura de entrada de dados do Modelo SMAP na versão mensal (Para geração da série histórica de vazão)..................................... 61

3 Dados de entrada para a calibração do modelo SMAP - versão

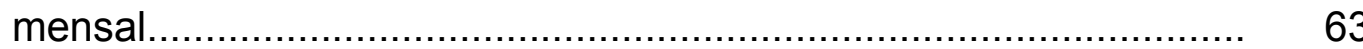

4 Relatório final da calibração chuva - vazão para o Rio Grande de Ubatuba

5 Dados de entrada para a validação do modelo SMAP - versão mensal

6 Relatório final da validação do Modelo SMAP para o Rio Grande de Ubatuba

7 Dados de entrada para a geração da série histórica, pelo modelo SMAP G

8 Resultados médios anuais para a série histórica gerada................. 74

9 Vazão de referência utilizada para outorga de água......................... 79

10 Captações superficiais para o abastecimento público de Ubatuba

11 Número de meses que a demanda é maior ou menor que a disponibilidade de água para abastecimento e, o porcentual de meses que a disponibilidade é menor que a demanda 
12 Estimativa da população de Ubatuba abastecida pelo Rio Grande

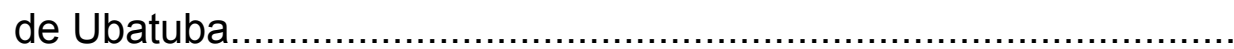

13 Vazão media mensal $\left(\mathrm{m}^{3} / \mathrm{s}\right)$, vazão média mensal disponível $\left(\mathrm{m}^{3} / \mathrm{s}\right)$, população máxima (habitantes /dia) que pode ser

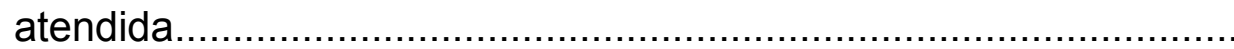

14 Vazão media mensal $\left(\mathrm{m}^{3} / \mathrm{s}\right)$, vazão média mensal disponível $\left(\mathrm{m}^{3} / \mathrm{s}\right)$, população máxima (habitantes /dia) que pode ser atendida. (Ano mais chuvoso da série - 1966-1967).......................

15 Vazão media mensal $\left(\mathrm{m}^{3} / \mathrm{s}\right)$, vazão média disponível $\left(\mathrm{m}^{3} / \mathrm{s}\right)$, população máxima (habitantes /dia) que pode ser atendida (Ano mais seco da série - 1955-1956) 


\section{LISTA DE SIGLAS}

CATI

CBH-LN

CETESB

CONAMA

DAEE

DEPRN

DNAEE

ESALQ

ETA

FEHIDRO

IBGE

IPEF

ITESP

PESM

PMU

SABESP

SEADE

SMAP

UNESCO
Coordenadoria de Assistência Técnica Integral

Comitê de Bacias Hidrográficas do Litoral Norte

Companhia de Tecnologia de Saneamento Ambiental

Conselho Nacional do Meio Ambiente

Departamento de Águas e Energia Elétrica

Departamento Estadual de Proteção dos Recursos Naturais Departamento Nacional de Águas e Energia Elétrica

Escola Superior de Agricultura Luiz de Queiroz

Estação de Tratamento de Água

Fundo Estadual de Recursos Hídricos

Instituto Brasileiro de Geografia e Estatística

Instituto de Pesquisas e Estudos Florestais

Instituto de terra do Estado de São Paulo

Parque Estadual da Serra do Mar

Prefeitura Municipal de Ubatuba

Companhia de Saneamento Básico do Estado de São Paulo

Sistema Nacional de Análise de Dados

Soil Moisture Accouting Procedure

Organização das Nações Unidas para a educação, a ciência e a cultura. 


\title{
GERAÇÃO DA SÉRIE HISTÓRICA DE VAZÃO POR MEIO DO MODELO SMAP: SUBSÍDIO PARA O PLANO DE MANEJO DA BACIA DO RIO GRANDE DE UBATUBA.
}

\author{
Autora: VIVIANE BUCHIANERI \\ Orientador: Prof. Dr. WALTER DE PAULA LIMA
}

\section{RESUMO}

A bacia hidrográfica do Rio Grande de Ubatuba $\left(26 \mathrm{Km}^{2}\right)$ encontra-se quase que totalmente recoberta com vegetação nativa da Mata Atlântica, e grande parte está inserida no interior do Parque Estadual da Serra do Mar. O Rio Grande é um manancial estratégico para o município, pois abastece $88 \%$ da população, que recebe água tratada de serviço público. Com o propósito de conhecer a potencialidade hídrica do manancial de forma a subsidiar tecnicamente a elaboração do Plano de Manejo para a bacia, o presente estudo foi conduzido para gerar a série histórica de vazão, usando o Modelo SMAP (Soil Moisture Accounting Procedure) e analisar $o$ balanço entre a disponibilidade e a demanda de água. Com apenas quatro anos incompletos de dados fluviométricos e com a série histórica de 67 anos de dados de precipitação, foi possível calibrar os parâmetros e validar o modelo com uma correlação de 0,838 entre as vazões estimada e observada e por último gerar a serie histórica de vazão. Com a série histórica de vazão gerada foi feita a análise temporal do balanço entre a disponibilidade e demanda que permitiram 
identificar a insuficiência hídrica para atender a demanda para abastecimento público ou para manutenção dos processos ecológicos do manancial, considerando três aspectos: a flutuação da população, a ocorrência de anos hídricos secos e, mesmo nos anos hídricos normais, ocorrência de períodos de meses secos prolongados. Com base na análise conjunta dos resultados, algumas ações consideradas compatíveis para a prevenção de possível escassez de água no futuro foram formuladas, visando proporcionar melhor qualidade de vida à população. 


\title{
GENERATING STREAMFLOW RECORDS THROUGH THE SMAP MODEL: A CONTRIBUTION FOR THE ELABORATION OF THE MANAGEMENT PLAN FOR THE RIO GRANDE WATERSHED, UBATUBA.
}

\author{
Author: VIVIANE BUCHIANERI \\ Adviser: Prof. DR. WALTER DE PAULA LIMA
}

\section{SUMMARY}

The Rio Grande Watershed of Ubatuba $\left(26 \mathrm{~km}^{2}\right)$ is almost completely covered with native Atlantic Rainforest vegetation, and a large part is within the bounds of the Serra do Mar State Park. The Rio Grande is a strategic water source for the municipality, supplying $88 \%$ of the population demand with treated water via a public service. In order to analyse the water potential of the source and to acquire technical information for the preparation of the Watershed Management Plan, this study was carried generate streamflow historic data, using the SMAP (Soil Moisture Accounting Procedure) model. This, in turn, permitted to analyse the balance between demand and availability of water.With only 4 years of incomplete streamflow data and 67 years of rainfall data, it was possible to calibrate the parameters and validate the model with a correlation of 0.838 between the estimated and observed flows, and finally produce a streamflow history. To produce the streamflow history, a time analysis was carried out with the balance between availability and demand, which allowed the 
identification of water shortages for public supply, as well as for the maintenance of the stream ecological processes, considering the following three aspects: population fluctuations, the occurrence of drought years and, even in normal years, the occurrence of extended periods of drought. 


\section{INTRODUÇÃo}

Situada no Litoral Norte do Estado de São Paulo e distante apenas $250 \mathrm{Km}$ da capital, a cidade de Ubatuba apresenta forte vocação turística, determinada principalmente por sua localização geográfica e pelos seus atributos naturais. A paisagem, formada por um mosaico de ilhas, praias, restingas, florestas e serras entrecortadas por rios e cachoeiras, constitui beleza cênica diferenciada das demais regiões litorâneas.

A economia atual voltada ao setor turístico e imobiliário tem proporcionado um grande fluxo migratório para a região, incrementando significativamente o crescimento populacional da cidade, que é atualmente de $3,9 \%$, ou seja, $2,1 \%$ percentuais acima da média estadual, que é de $1,8 \%$ ao ano, de acordo com os levantamentos realizados pela Fundação SEADE (Sistema Estadual de Análise de Dados), no período de 1991 a 2000 .

O crescimento urbano tem sido caracterizado pela expansão irregular da periferia com pouca obediência à regulamentação urbana relacionada com a lei de uso do solo e normas específicas para loteamentos. A ocupação irregular atinge a zona de amortecimento do Parque Estadual da Serra do Mar e, em alguns bairros, o interior da unidade de conservação.

Dentre os impactos relacionados a esse processo de desenvolvimento urbano, que vem se reproduzindo em cidades com altas taxas de crescimento anual, destaca-se a grande descarga de efluentes domésticos e pluviais sem tratamento que são despejados nos rios. Além disso, grandes volumes de material sólido do lixo também são despejados e, como conseqüência, agravam-se os problemas de inundação urbana. Esse cenário tem impacto 
direto sobre a saúde da população, pois $65 \%$ das internações hospitalares no Brasil são provenientes de doenças transmitidas pela água (Tucci, 2002).

No município de Ubatuba existem cinco sistemas de abastecimento públicos, atendendo $87 \%$ da população. O Sistema Estação de Tratamento de Água (ETA) Carolina é responsável pelo abastecimento de $88 \%$ da população que recebe água tratada no município, sendo o maior sistema da cidade. A ETA Carolina foi implantada pela Companhia de Saneamento Básico do Estado de São Paulo (SABESP) e entrou em operação no final de 1998. É abastecida pelos mananciais do Rio Grande e Cachoeira dos Macacos, sendo o primeiro o que representa a maior contribuição em termos de quantidade de água do sistema. O tratamento é constituído pelas operações filtração, desinfecção e fluoretação.

No Rio Grande, o volume de água captado pela SABESP é de $598 \mathrm{l} / \mathrm{s}$ no verão e 234 l/s no inverno (IPT, 2000). Consulta realizada no Processo SMA 89.036/93 que se encontra em trâmite junto ao Departamento Estadual dos Recursos Naturais, em Ubatuba, o sistema ETA Carolina foi projetado para abastecer 95\% da população fixa e flutuante, ou seja, cerca de 200.000 habitantes até o ano de 2006, cobrindo, além da região central, a região norte até o bairro de Itamambuca, e a região sul até a Praia do Lázaro.

Grande parte da bacia encontra-se recoberta com vegetação nativa da Mata Atlântica, e a região foi reconhecida pela UNESCO como "Reserva da Biosfera da Mata Atlântica", no programa Man and Biosphere (MAB), colocando-a como um patrimônio da humanidade.

Os afluentes e as nascentes do Rio Grande encontram-se na escarpa do Parque Estadual da Serra do Mar (PESM), que é considerado pelo Sistema Nacional de Unidade de Conservação como Unidade de Proteção Integral, cujo objetivo de manejo visa à manutenção dos ecossistemas livres de alterações causadas por interferência humana, admitindo apenas o uso indireto dos seus atributos naturais. O Parque Estadual da Serra do Mar tem seus limites na cota 
100m, e o ponto de captação de água de abastecimento encontra-se na cota $37,5 \mathrm{~m}$.

Apesar da Bacia do Rio Grande de Ubatuba encontrar-se quase que totalmente recoberta com floresta, o que proporciona uma oferta de água de boa qualidade, o risco de degradação do manancial é iminente, em conseqüência do processo de expansão urbana desordenada.

Dentro desse contexto, o presente trabalho tem como objetivo principal estimar a disponibilidade hídrica na bacia do Rio Grande, em termos quantitativos, de forma a subsidiar tecnicamente a elaboração do Plano de Manejo Participativo, a fim de garantir o suprimento de água potável para a população de Ubatuba.

Dentro desse propósito, os objetivos específicos deste trabalho são:

a) calibrar e validar, por meio do modelo SMAP (Lopes, et al., 1982), a relação chuva-vazão da bacia do Rio Grande de Ubatuba.

b) gerar a série histórica de vazões mensais por meio do modelo SMAP;

c) realizar análise temporal da disponibilidade e demanda de água para abastecimento público na bacia hidrográfica. 


\section{A CONTEXtualizaçÃo ATUAL do PROJeto DE PESQUisa PARTICIPATIVA}

Thomas Kuhn, físico americano, diz que o que caracteriza a ciência não é o uso do método científico, mas o consenso da comunidade científica: o consenso é a adoção de um paradigma. Em "A estrutura das revoluções científicas", publicado em 1970, o autor designa "paradigma" como sendo as realizações científicas que geram modelos que, por períodos mais ou menos longos e de modo mais ou menos explícito, orientam o desenvolvimento posterior das pesquisas. $\mathrm{Na}$ sociedade humana esses modelos possuem uma série de elementos sociais, econômicos e culturais que permanecem estáveis por longo período de tempo, até que novos períodos de desequilíbrio, incertezas e instabilidades começam a surgir, delineando então novos modelos, causando um período de transição e ruptura com o antigo, antes que um novo período de acomodação, estabilidade e equilíbrio ocorra (Buchianeri, 2004).

O físico Fritjof Capra (1992) tomou de Kuhn a definição sobre paradigmas e a ampliou da ciência para o âmbito da sociedade. Um paradigma social é um conjunto de conceitos, valores, percepções e práticas compartilhadas por uma comunidade, que forma uma visão particular da realidade, o que, por sua vez, determina a própria forma de organização da comunidade. É importante destacar a dimensão comunitária: uma pessoa pode ter uma perspectiva global, mas o paradigma há de ser compartilhado no interior da comunidade. Hoje em dia pode-se dizer que as ameaças representadas pela devastação do meio ambiente e a persistência da pobreza, 
problemas impossíveis de resolver pelo antigo paradigma, não são mais que a indicação de que o paradigma social alcançou seus limites (Gomes,2003).

De forma resumida, portanto, pode-se dizer que o paradigma da ciência ocidental encontrou alguns de seus fundamentos no empirismo (o conhecimento obtido pela experiência repetida), no racionalismo (a redução do todo a partes pequenas para melhor estudá-las, e que teve como corolário a especialização) e no positivismo, ou conhecimento objetivo e verdadeiro da realidade estudada, pois a pesquisa, para ser científica, tem de ser testada, provada (Gomes,2003).

Não se sabe muito bem em que período estamos, mas há evidências de mudanças paradigmáticas na compreensão humana do mundo. Alguns autores definem o momento atual como uma ruptura com antigos paradigmas. Outros, como um período de transição, em que há uma intersecção de modelos. Essa observação pode ser descrita como o advento da condição "pós-moderna", ou seja, a etapa intermediária entre o esgotamento da "modernidade" e o período que a irá suceder (Buchianerl, 2004).

Funtowicz \& Ravetz (1993) desenvolveram o conceito de ciência pósnormal, que trata de estratégias de resolução de problemas adequadas a esse contexto. Os novos problemas relacionados a riscos e ao meio ambiente têm aspectos comuns que os distinguem dos problemas científicos tradicionais: os fatos são incertos, os valores, controvertidos, as apostas, elevadas e as decisões, urgentes (Funtowicz \& Ravetz,1997). Ainda, de acordo com os autores, a função essencial de controle de qualidade ambiental e avaliação crítica não pode mais ser desempenhada por um corpo restrito de especialistas. O diálogo sobre a qualidade e a formulação de políticas deve ser estendido a todos os afetados pela questão, que formam o que se chama de "comunidade ampliada dos pares".

De acordo com Gomes(2003), o conceito de ciência pós-normal desenvolvido por Funtowicz \& Ravetz(1993) não pretende neutralidade ética nem ignora as conseqüências políticas do uso da ciência na sociedade 
moderna, como defendem empiristas, racionalistas e positivistas; simplesmente, ela pretende um tipo de "ciência com as pessoas". Na resolução de problemas complexos, não basta superar as incertezas cognitivas, a elas somam-se as incertezas éticas derivadas dos valores conflitivos da sociedade. A ciência pósnormal é recomendada para sair do reducionismo dominante nas "comunidades restringidas de pares", levando a tomada de decisão para o âmbito das "comunidades estendidas de pares", através do debate mais amplo com toda a sociedade, ou promovendo democratização na produção e circulação do conhecimento, o que requer a participação dos sujeitos implicados no processo.

De certa forma, essas idéias de transdiciplinaridade fizeram parte da preparação de estratégias para a construção de um plano de manejo integrado para a bacia do Rio Grande, buscando conhecer a potencialidade hídrica do principal manancial abastecedor da cidade de Ubatuba, a partir de discussões entre os diversos setores da sociedade, visando à conservação da bacia, de forma a garantir o suprimento de água de boa qualidade para a população atual e futura.

O maior conflito do uso da água nesta bacia é com relação à ocupação do solo. Cabe destacar que o manancial do Rio Grande tem todas as nascentes e a foz dentro do limite territorial do município de Ubatuba, não havendo, portanto "disputas de água" com outros municípios. Além disso, acima da captação de água, não existem centros industriais ou grandes áreas agrícolas que poderiam potencializar o risco de degradação do manancial.

Destaca-se a existência de diferentes tipos de conflitos com relação ao uso do espaço territorial. Existe a população que vem ocupando gradativamente o Parque Estadual da Serra do Mar, desmatando floresta e as matas ciliares. Essa população é composta, na maioria, de migrantes que chegam ao município para trabalhar em serviços temporários, dando atendimento para a demanda turística ou da construção civil. Existe uma rotatividade muito grande de pessoas nessa região, e isso ocorre em função da existência da unidade de 
conservação e dos instrumentos judiciais que cada vez se tornam mais rígidos no tratamento das ocupações ilegais.

Entre a cota de captação de água (cota $37,5 \mathrm{~m}$ ) e a cota que delimita o início do Parque Estadual da Serra do Mar (cota 100m), a população ali estabelecida é fixa, recebe quase todos os serviços públicos, tais como: manutenção de sistema viário, coleta de lixo, telefone, energia elétrica, escola, porém, não recebe água tratada da concessionária pública, o que obriga a utilizar a água proveniente dos afluentes do Rio Grande, retirando um volume de água considerável e que não está sendo monitorado nem pela concessionária (SABESP) nem pelo órgão fiscalizador (DAEE). A água não é fornecida por algumas razões, dentre elas a existência de loteamentos não regularizados pelo poder público e também os custos operacionais que a empresa concessionária deveria investir para levar água para aquela região por bombeamento. Outro fator alegado pela empresa concessionária diz respeito à dificuldade de fazer com que todos os moradores da região façam conexão na rede da SABESP, uma vez que predominam moradores com baixo poder aquisitivo e que estão acostumados a receber água direto do manancial, sem necessidade de pagar pelo serviço de tratamento.

Paralelamente, tem-se a população beneficiária do sistema de água tratada, cuja preocupação é com a manutenção da qualidade e quantidade de água fornecida pela concessionária. Essa preocupação está respaldada no fato do Rio Grande ser o segundo maior manancial com volume de água existente no município e estar localizado na bacia de maior concentração de habitantes.

Notadamente existem dois tipos de interesses relevantes dentro da comunidade, como por exemplo o interesse meramente territorial, no qual parte da população está fixada em local de grande contribuição hídrica para a bacia, e o interesse pelo uso da água, ou seja, a garantia de recebimento de água potável.

Entretanto, somam-se a isso outros interesses das instituições setoriais, destacando o Instituto Florestal, cuja preocupação é com a conservação da 
biodiversidade do parque, a CETESB, preocupada com a qualidade da água do manancial, o Departamento de Águas e Energia Elétrica (DAEE), com a quantidade de água, a Secretaria Estadual da Saúde e a Vigilância Sanitária, preocupadas com a saúde da população, a SABESP, com a distribuição de água, o Departamento Estadual de Proteção dos Recursos Naturais (DEPRN), com a preservação da vegetação nativa, a Secretaria de Arquitetura e Urbanismo, preocupada com o ordenamento do espaço territorial, a Secretaria da Agricultura, com as pessoas que desenvolvem agricultura de subsistência, e o Instituto de Terras do Estado de São Paulo (ITESP), preocupado com a questão fundiária. Existem também instituições articuladoras que desenvolvem algum trabalho com a comunidade nesta bacia e os órgãos fiscalizadores, como a Policia Ambiental e Ministério Público do Estado de São Paulo.

Diante desse cenário, foi concebido o projeto "Manancial do Rio Grande: Potencialidade e Riscos" que foi aprovado pelo Comitê de Bacias Hidrográficas do Litoral Norte (CBH-LN) para recebimento de recursos financeiros junto ao Fundo Estadual de Recursos Hídricos (FEHIDRO). Contemplando a parceria entre a Escola Superior de Agricultura Luiz de Queiroz (ESALQ), o Instituto de Pesquisa e Estudo Florestais (IPEF) e o Instituto Florestal (IF), um dos pressupostos desse projeto é a elaboração, por meio de processo participativo, de um plano de manejo específico para a bacia do Rio Grande.

Este plano vem sendo construído e implementado por um grupo de trabalho estabelecido em julho de 2000 , no âmbito do próprio CBH-LN, que é composto por técnicos de instituições governamentais como a CETESB, SABESP, Secretaria Estadual da Saúde, DAEE, ITESP, DEPRN, Secretaria da Agricultura e Abastecimento, Secretaria de Arquitetura e Urbanismo e Vigilância Sanitária, Secretaria de Agricultura e Pesca (PMU), Ministério Público Estadual, Polícia Ambiental, organizações não governamentais como Sociedade Amigos do Pé da Serra, Sindicato dos Trabalhadores Rurais, Sociedade Amigos da Praia das Toninhas e a ESALQ/USP. 
Sucintamente, as etapas para a elaboração do Plano de Manejo Integrado, segundo Buchianeri et al.(2003) foram:

1. identificação dos problemas da bacia através do método de visualização, no qual cada problema percebido foi sendo transcrito em fichas e colocadas em um painel, no qual os participantes puderam identificar e classificar os diferentes riscos para a Bacia do Rio Grande de Ubatuba. O painel de identificação dos problemas encontra-se na Figura 1. Procedeu-se, então, à transformação dos problemas em objetivos, resultando no painel apresentado na Figura 2. 


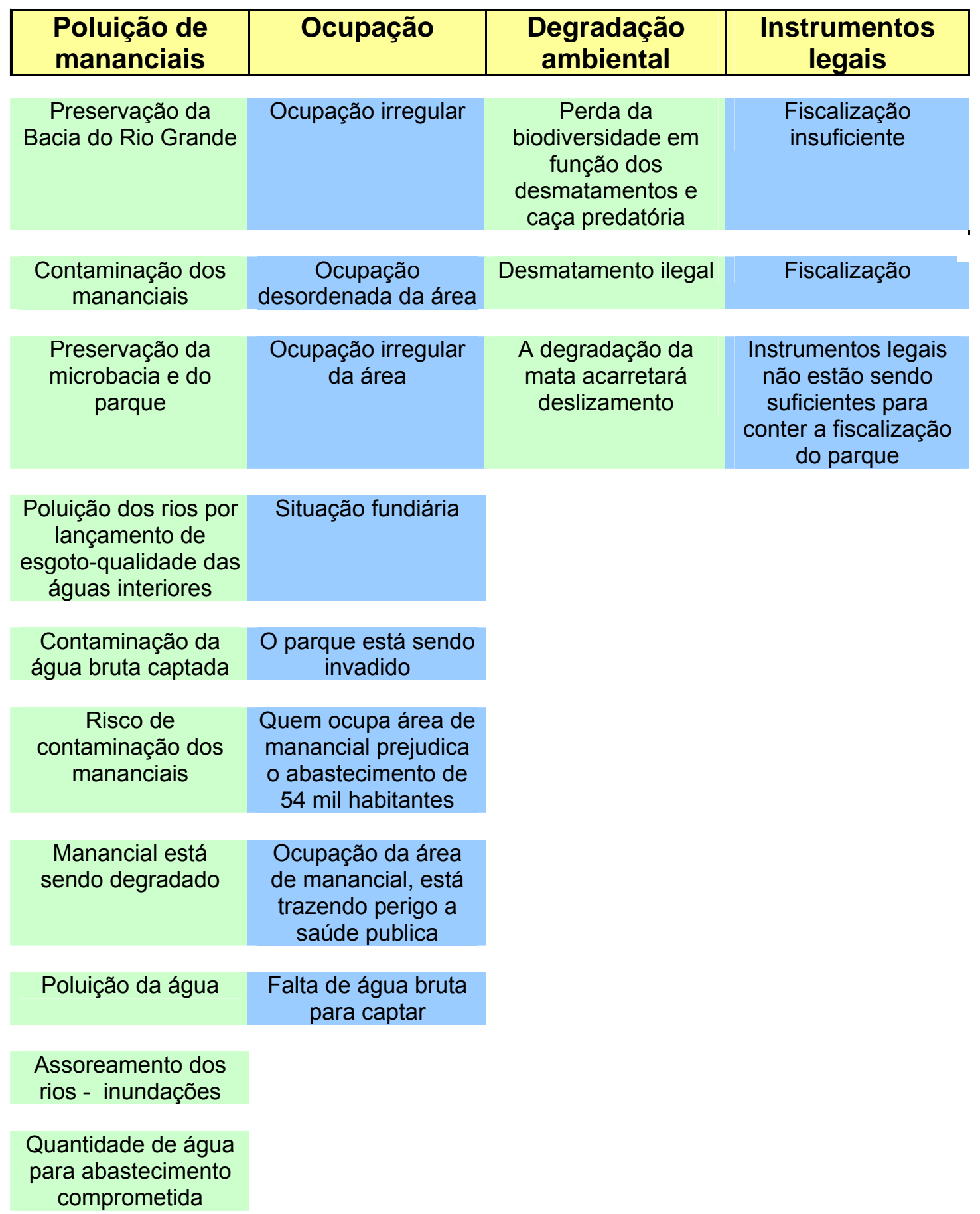

Figura 1 - Painel de identificação dos problemas 


\begin{tabular}{|c|c|c|c|c|c|c|}
\hline 1 & 2 & 3 & 4 & 5 & 6 & 7 \\
\hline$\frac{\begin{array}{c}\text { Realizar a } \\
\text { caracterização }\end{array}}{\frac{\text { hidrológica do }}{\text { Rio Grande }}}$ & $\begin{array}{c}\text { Capacitar em } \\
\text { termos legais } \\
\text { as diferentes } \\
\text { instituições e } \\
\text { sociedade } \\
\text { civil }\end{array}$ & $\begin{array}{c}\text { Priorização da } \\
\text { questão do uso } \\
\text { e ocupação do } \\
\text { solo com parte } \\
\text { fundamental da } \\
\text { política pública } \\
\text { municipal }\end{array}$ & $\begin{array}{c}\text { Inibir novas } \\
\text { ocupações por } \\
\text { meio de } \\
\text { observações } \\
\text { controladas }\end{array}$ & $\begin{array}{c}\text { Capacitar } \\
\text { órgãos } \\
\text { fiscalizadores }\end{array}$ & $\begin{array}{l}\text { Realizar fórum } \\
\text { de } \\
\text { desenvolvimento } \\
\text { participativo }\end{array}$ & $\begin{array}{c}\text { Buscar } \\
\text { cooperação } \\
\text { junto aos } \\
\text { organismos } \\
\text { competentes, } \\
\text { no auxílio aos } \\
\text { moradores que } \\
\text { serão } \\
\text { remanejados }\end{array}$ \\
\hline $\begin{array}{c}\text { Caracterizar o } \\
\text { Rio Cachoeira } \\
\text { dos Macacos }\end{array}$ & $\begin{array}{l}\text { Demarcar e } \\
\text { sinalizar o } \\
\text { parque }\end{array}$ & $\begin{array}{l}\frac{\text { Apresentar para }}{\frac{\text { a comunidade }}{\text { local a }}} \\
\frac{\text { contextualização }}{\text { do problema }}\end{array}$ & $\begin{array}{l}\text { Austeridade na } \\
\text { fiscalização } \\
\text { PAMB, } \\
\text { IF,DPRN,PMU }\end{array}$ & $\begin{array}{l}\text { Contratação } \\
\text { de pessoal, }\end{array}$ & & $\begin{array}{l}\text { Definir } \\
\text { juridicamente a } \\
\text { propriedade } \\
\text { das áreas }\end{array}$ \\
\hline $\begin{array}{l}\text { Controlar a } \\
\text { qualidade da } \\
\text { água bruta e } \\
\text { tratada } \\
\text { CETESB e } \\
\text { SABESP }\end{array}$ & $\begin{array}{l}\text { Integrar os } \\
\text { agentes } \\
\text { públicos }\end{array}$ & $\begin{array}{c}\text { Definir a quem } \\
\text { caberá o ônus } \\
\text { de dar } \\
\text { estruturação } \\
\text { para as famílias } \\
\text { em outras áreas }\end{array}$ & $\begin{array}{l}\text { Colocar placas } \\
\text { nas áreas } \\
\text { abandonadas, } \\
\text { indicando estar } \\
\text { sob } \\
\text { responsabilidade } \\
\text { do IF (em } \\
\text { recuperação) }\end{array}$ & $\begin{array}{l}\text { Aquisição de } \\
\text { equipamentos }\end{array}$ & & $\begin{array}{c}\text { Realizar o } \\
\text { levantamento } \\
\text { sócioeconômico }\end{array}$ \\
\hline $\begin{array}{l}\text { Embargar } \\
\text { todas as } \\
\text { áreas da } \\
\text { bacia, } \\
\text { evitando } \\
\text { aumento da } \\
\text { degradação }\end{array}$ & $\begin{array}{l}\text { Contratar } \\
\text { pessoal } \\
\text { capacitado }\end{array}$ & $\begin{array}{l}\text { Tipologia dos } \\
\text { ocupantes da } \\
\text { bacia - Realizar } \\
\text { levantamento } \\
\text { sócioeconômico }\end{array}$ & & $\begin{array}{l}\text { Proposta de } \\
\text { transformar a } \\
\text { comunidade } \\
\text { em agente de } \\
\text { observação } \\
\text { controlada }\end{array}$ & & $\begin{array}{c}\text { Realizar } \\
\text { levantamentos } \\
\text { para } \\
\text { caracterizar a } \\
\text { situação } \\
\text { fundiária }\end{array}$ \\
\hline $\begin{array}{c}\text { Viabilizar a } \\
\text { retirada das } \\
\text { pessoas nas } \\
\text { áreas mais } \\
\text { sensíveis }\end{array}$ & $\begin{array}{l}\text { Oficina de } \\
\text { trabalho para } \\
\text { conhecimento } \\
\text { da função e } \\
\text { atribuição de } \\
\text { cada órgão }\end{array}$ & $\begin{array}{l}\text { Programa de } \\
\text { apoio às } \\
\text { famílias } \\
\text { Educação } \\
\text { Ambiental } \\
\text { Incentivo ao } \\
\text { reflorestamento }\end{array}$ & & $\begin{array}{c}\text { Integrar } \\
\text { equipes de } \\
\text { fiscalização } \\
\text { com a } \\
\text { comunidade }\end{array}$ & & $\begin{array}{l}\text { Elaborar } \\
\text { projetos de } \\
\text { educação } \\
\text { ambiental }\end{array}$ \\
\hline $\begin{array}{l}\text { Estabelecer } \\
\text { as áreas } \\
\text { prioritárias e } \\
\text { critérios para } \\
\text { desocupação }\end{array}$ & $\begin{array}{c}\text { Definição de } \\
\text { protocolo } \\
\text { entre órgãos } \\
\text { para } \\
\text { agilização } \\
\text { das ações e } \\
\text { resolutividade }\end{array}$ & $\begin{array}{l}\text { Retomada do } \\
\text { projeto de } \\
\text { alfabetização e } \\
\text { agricultura de } \\
\text { baixo impacto } \\
\text { (manejo) }\end{array}$ & & & & $\begin{array}{l}\frac{\text { Propor }}{\text { soluções }} \\
\frac{\text { técnicas para }}{\text { minimizar os }} \\
\frac{\text { impactos }}{\text { (saúde e meio }} \\
\frac{\text { ambiente), }}{\text { respeitando a }} \\
\text { situação local }\end{array}$ \\
\hline $\begin{array}{c}\frac{\text { Estimar o }}{\text { preço da }} \\
\frac{\text { floresta como }}{\text { produtora de }} \\
\text { água }\end{array}$ & & $\begin{array}{c}\text { Influenciar a } \\
\text { definição do uso } \\
\text { do solo e } \\
\text { ocupação do } \\
\text { solo pela PMU }\end{array}$ & & & & \\
\hline
\end{tabular}

Figura 2 - Painel dos objetivos 
2. após a identificação dos problemas da bacia e seus objetivos específicos, foram formados quatro subgrupos temáticos, quais sejam: i) proteção, conservação e recuperação de áreas degradadas; ii) gestão; iii) quantidade e qualidade de água; iv) divulgação, capacitação e conscientização ambiental. Foram construídas matrizes de planejamento contemplando os seguintes itens: ações, atividades, metas, prazos, atores diretos, parceiros, fontes de financiamentos. As Figuras 3, 4, 5 e 6 apresentam as matrizes de planejamento elaboradas .

3. e, finalmente, a implementação e a reavaliação do plano de manejo participativo. 


\begin{tabular}{|c|c|c|c|c|c|c|c|}
\hline Tema & Açöes de Melhoramento Ambiental & Atwidades & Metas & Prazos & Responsáveis & Entidades de Apoio & Fonte de Financ. \\
\hline Monitoramento da quantidade da água & $\begin{array}{l}\text { Realizar estudos de caracterização hidrológica } \\
\text { da Eacia do Rio Grande }\end{array}$ & $\begin{array}{l}\text { Determinar a vazão do Rio Grande, gerar série histórica, } \\
\text { fazer estudo de disponibilidade e demandas hídricas }\end{array}$ & $\begin{array}{c}\text { Estudo elaborado e } \\
\text { disponibilizado ao público }\end{array}$ & Médio & IFIPEFIESALQ & GT-Rio Grande & FEHIDRO \\
\hline Conservaçẫo da quantidade de água & Assoreamento dos Rios e Inundaçốes & Manutençẫo e recuperaçã̃o da margens Riosi Orientaçẫo & $\begin{array}{l}\text { Preservar as faixas } \\
\text { marginais }\end{array}$ & Médio & DEPRNSPAMES IFIPMU & $\begin{array}{c}\text { UNITAUISAPESIACICESPI } \\
\text { Emp.Privadasi }\end{array}$ & Fehidroíconvênios \\
\hline Conservação da quantidade de água & \begin{tabular}{|c|} 
Distribuiçăo de dégua pela SAEESP para as \\
propriedades localizadas entre cota $40 \mathrm{e} 100 \mathrm{~m}$
\end{tabular} & $\begin{array}{l}\text { Fazer estudo técnico e identificar locais para instalaçẫo } \\
\text { de equipamentos }\end{array}$ & $\begin{array}{c}\text { Aprovar projetos nos órgẫos } \\
\text { licenciadores }\end{array}$ & Médio & $\begin{array}{l}\text { SAEESPIA sociação dos } \\
\text { Engenheiros }\end{array}$ & DAEEIGT-RIO GRANDE & SAEESP \\
\hline Proteçăo da Bacia & Intensificar a fiscalizaçăo preventiva & Realizar fiscalização integrada -IF-PAMB-DEPRN-PMU & $\begin{array}{l}\text { Fiscalização conjunta } \\
\text { 4æimês }\end{array}$ & Curto & $\begin{array}{c}\text { IFI } \\
\text { PAMBIDEPRNiPrefeitura }\end{array}$ & $\begin{array}{l}\text { Ministério } \\
\text { PúblicoiAssociaçẫo dos } \\
\text { Engenheiros }\end{array}$ & $\begin{array}{l}\text { Órgåos Públicos } \\
\text { Estaduais }\end{array}$ \\
\hline Proteçăo da Bacia & $\begin{array}{l}\text { Elaborar o relatório sobre a ocupação na área } \\
\text { do PESM }\end{array}$ & $\begin{array}{c}\text { Reunir dados existentes na PAME e IF/Realçizar vistorias } \\
\text { técnicas }\end{array}$ & $\begin{array}{l}\text { Diagnosticar o Impacto da } \\
\text { ocupaçäo nos recursos } \\
\text { hidricos }\end{array}$ & Curto & IF/GT-Rio Grande & Ministerio Público & $\begin{array}{l}\text { Órgẫos Públicos } \\
\text { Estaduais }\end{array}$ \\
\hline Proteçăo da Bacia & $\begin{array}{l}\text { Embargar Judicialmente toda área da Bacia, } \\
\text { evitando o aumento da degradaçãoc }\end{array}$ & $\begin{array}{c}\text { Encaminhar o relatório de ocupaçăo ao Ministério Público } \\
\text { Estadual }\end{array}$ & $\begin{array}{c}\begin{array}{c}\text { Estagnar a atividade } \\
\text { antrópica }\end{array} \\
\end{array}$ & Curto & $\begin{array}{l}\text { Ministério PúblicoiPoder } \\
\text { Judiciário }\end{array}$ & $\begin{array}{l}\text { IFIPAMEIDEPRNJPMUIGT- } \\
\text { RG }\end{array}$ & $\begin{array}{l}\text { Órgåos Públicos } \\
\text { Estaduais }\end{array}$ \\
\hline Proteçăo da Bacia & $\begin{array}{l}\text { Realizar a demarcaçăo do Parque Estadual da } \\
\text { Serra do Mar }\end{array}$ & $\begin{array}{c}\text { Encaminhar ofícios à Procuradoria do Estado/Secretaria } \\
\text { do Meio Ambiente e Secret.Recursos Hídricos solicitando } \\
\text { providências }\end{array}$ & $\begin{array}{l}\text { Tornar público o limite do } \\
\text { PESM }\end{array}$ & Curto & \begin{tabular}{|l|} 
Procuradoria Geral do \\
Estado IInstituto Florestalls \\
Câmara Municipal e \\
Ministério Público
\end{tabular} & IFIITESPISMA & $\begin{array}{l}\text { FNMAiRecursos } \\
\text { Estaduais }\end{array}$ \\
\hline $\begin{array}{l}\text { Proteçẫo da Bacia dentro dos limites } \\
\text { do PESM }\end{array}$ & $\begin{array}{l}\text { Viabilizar a retirada das pessoas nas áreas } \\
\text { mais sensiveis }\end{array}$ & $\begin{array}{l}\text { Realizar o levantamento sócioeconômico dos } \\
\text { ocupantesiRealizar embargos judiciais }\end{array}$ & $\begin{array}{l}\text { Acelerar a recuperą̧ẵo } \mathrm{e} \\
\text { minimizar o impacto da }\end{array}$ & Médio & $\begin{array}{l}\text { Ministério Público } \\
\text { s/fiEs salq }\end{array}$ & GT-Rio Grande & $\begin{array}{l}\text { Fehidroóórgâos } \\
\text { Públicos. }\end{array}$ \\
\hline Protę̧ăa da Bacia & Realocar moradares de baixo poder aquisitivo & 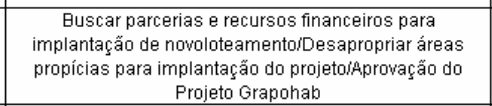 & Minimizar o problema social & Médio & PMU & $\begin{array}{l}\text { SATIIFIPAMAIDEPRNAETE } \\
\text { S日 }\end{array}$ & \begin{tabular}{|l} 
Recursos \\
Estaduais CEPAM
\end{tabular} \\
\hline Riscos potenciais à saúde pública & 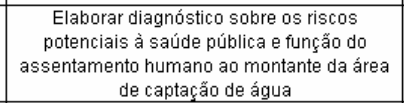 & Lewantamento dos principais problemas & Elaborar parecer técrico & Culto & $\begin{array}{l}\text { Secretaria Estadual da } \\
\text { Saúdel CetesblGabespi } \\
\text { IFifolicia } \\
\text { AmbientaliDEFRN }\end{array}$ & Minisistérió Fúblico & Órgåas públicos \\
\hline Monitoramento da Qualidade da Água & $\begin{array}{l}\text { Monitoramento da água na captą̧ăo de ảgua } \\
\text { do Rio Grande e Cachoeira do Macaco }\end{array}$ & 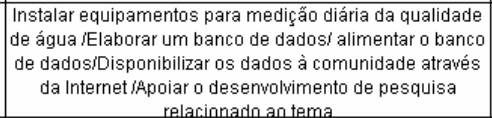 & 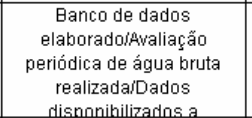 & Médio & Cetesb & \begin{tabular}{|c|} 
SabespiSecretaria de \\
Saúdeilunicampiluniwersida \\
des
\end{tabular} & $\begin{array}{l}\text { Orgắn Públicas } \\
\text { Fapesp outras } \\
\text { fontes }\end{array}$ \\
\hline 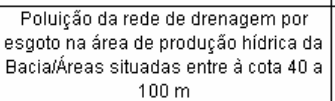 & $\begin{array}{c}\text { Estudar a posibilidade de realização de } \\
\text { pessoal das âreas mais sensiveis da Eacia } \\
\text { altzo } \mathrm{CF}\end{array}$ & $\begin{array}{c}\text { Realizar estuddos parat ildertificata as áreas mais } \\
\text { sensiveisilevantar onumero de moradores que se } \\
\text { encontram nesta área }\end{array}$ & \begin{tabular}{|c|} 
Estudos sealizados e \\
mapeadosica-dastramento \\
da populaça á realizado
\end{tabular} & Lango & $\begin{array}{l}\text { GT-Rio Grandei } \\
\text { IPEFIEBALQ }\end{array}$ & 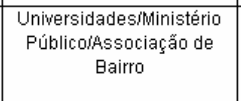 & $\begin{array}{l}\text { Ỏrgẵos Fúblicos } \\
\text { Estaduais }\end{array}$ \\
\hline 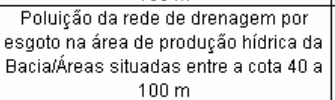 & \begin{tabular}{|c|} 
Estudar a proposta de constrụ̧ă $e$ \\
readequą̧äa de fossas dépticasilmplementar \\
a propsta
\end{tabular} & $\begin{array}{c}\text { Realizar o cadastramento dos moradoresirealizar testes } \\
\text { de infiltra̧äa em diversos pantos da Bacial Elaborar } \\
\text { projetos técnicosiorientar moradores }\end{array}$ & & Média & \begin{tabular}{|l|} 
PrefeituralGT-Rio Grande \\
\end{tabular} & $\begin{array}{l}\text { Ministério } \\
\text { Públicoiłassocią̧äa dos } \\
\text { Engenheiros }\end{array}$ & Fundo estadual \\
\hline 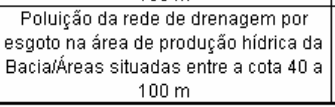 & $\begin{array}{l}\text { Estudar proposta de ligaşăo na rede da } \\
\text { Sabesp i implementar a proposta }\end{array}$ & Ampliar a rede de esgoto & & Múdio & Sabesp & GT-Rio Grande & órgäo Público \\
\hline
\end{tabular}

Figura 3 - Matriz de planejamento - Quantidade e qualidade da água (em destaque a atividade contemplada no presente trabalho) 


\begin{tabular}{|c|c|c|c|c|c|c|c|}
\hline Tema & $\begin{array}{c}\text { Ações de Melhoramento } \\
\text { Ambiental }\end{array}$ & Atividades & Metas & Prazos & Responsáveis & $\begin{array}{l}\text { Entidades } \\
\text { de Apoio }\end{array}$ & $\begin{array}{c}\text { Fonte de } \\
\text { Finaciamento }\end{array}$ \\
\hline $\begin{array}{l}\text { Recuperação de áreas } \\
\text { degradadas }\end{array}$ & $\begin{array}{l}\text { Elaborar projeto para } \\
\text { Viveiro Florestal }\end{array}$ & \begin{tabular}{|l|} 
Fazer estudo de \\
viabilidade de \\
montagem de viveiro e \\
elaborar projeto
\end{tabular} & $\begin{array}{l}\text { Tornar o Viveiro } \\
\text { auto sustentável }\end{array}$ & médio & IF/CBH-LN/PMU & $\begin{array}{l}\text { Sabesp/Unita } \\
\text { u/Prefeitura/ } \\
\text { CBH- } \\
\text { LN/STR/IAC }\end{array}$ & $\begin{array}{l}\text { Fehidro/ Fundaçấo } \\
\text { Boticário/Fundo } \\
\text { Meio Ambiente }\end{array}$ \\
\hline $\begin{array}{l}\text { Recuperaçấo de áreas } \\
\text { degradadas }\end{array}$ & Implantar Viveiro Florestal & $\begin{array}{l}\text { Definir equipe para } \\
\text { trabalhar no } \\
\text { viveiro/adquirir } \\
\text { equipamentos/elaborar } \\
\text { programa de coleta de } \\
\text { sementes/plantio das } \\
\text { sementes/transporte } \\
\text { das mudas } p / \text { campo }\end{array}$ & $\begin{array}{l}\text { Efetivaçẫo do } \\
\text { projeto de viveiro } \\
\text { de mudas com } \\
\text { apoio da } \\
\text { comunidade }\end{array}$ & longo & $\begin{array}{l}\text { IF/CBH- } \\
\text { LN/PMU/SAPES } \\
\text { /IPEF }\end{array}$ & $\begin{array}{l}\text { IPEF/PMU/A } \\
\text { C/CBH-LN }\end{array}$ & $\begin{array}{l}\text { Fehidro/ Fundaçã̃o } \\
\text { Boticário/Fundo } \\
\text { Meio Ambiente }\end{array}$ \\
\hline $\begin{array}{l}\text { Recuperaçã̃o de áreas } \\
\text { degradadas }\end{array}$ & $\begin{array}{l}\text { Cadastramento das áreas } \\
\text { prioritárias para o } \\
\text { reflorestamento }\end{array}$ & \begin{tabular}{|l|} 
Treinamento da equipe \\
para o cadastramento/ \\
priorizar áreas
\end{tabular} & $\begin{array}{l}\text { Áreas prioritárias } \\
\text { selecionadase } \\
\text { apoio da } \\
\text { comunidade na } \\
\text { recuperaçẫo } \\
\text { dessas áreas }\end{array}$ & curto & $\begin{array}{l}\text { SAPE/PMU/UNI } \\
\text { TAU/IF }\end{array}$ & $\begin{array}{l}\text { Unitau/Sapes } \\
\text { /IF/Prefeitura/ } \\
\text { STR }\end{array}$ & $\begin{array}{l}\text { Instituto Florestal, } \\
\text { Ministério Público, } \\
\text { VCP,UNITAU }\end{array}$ \\
\hline $\begin{array}{l}\text { Recuperação de áreas } \\
\text { degradadas }\end{array}$ & $\begin{array}{l}\text { Reflorestamento de mata } \\
\text { ciliar }\end{array}$ & $\begin{array}{l}\text { Elaboraçẫo de projeto } \\
\text { para cada } \\
\text { área/Assistência } \\
\text { técnica e } \\
\text { acompanhamento }\end{array}$ & $\begin{array}{l}\text { Implantaçã̃o da } \\
\text { recuperaçẫo e } \\
\text { acompanhamento } \\
\text { da evolução }\end{array}$ & longo & $\begin{array}{l}\text { SAPE/PMU/UNI } \\
\text { TAU/F }\end{array}$ & $\begin{array}{l}\text { IF/Unitau/SA } \\
\text { PES/Prefeitur } \\
\text { a/STR }\end{array}$ & $\begin{array}{l}\text { Fehidro/Iniciatica } \\
\text { privada }\end{array}$ \\
\hline $\begin{array}{l}\text { Fiscalização e } \\
\text { Monitoramento }\end{array}$ & $\begin{array}{l}\text { Elaborar programa de } \\
\text { monitoramento e } \\
\text { fiscalizaçẫo para inibir } \\
\text { novas ocupaçỗes }\end{array}$ & $\begin{array}{l}\text { Fiscalização efetiva } \\
\text { através dos orgẫos já } \\
\text { existentes } \\
\text { PAMB/DEPRN/Prefeit } \\
\text { ura/ participaçẫo } \\
\text { voluntária da } \\
\text { comunidade no } \\
\text { monitoramento. }\end{array}$ & $\begin{array}{l}\text { Articulaçẫo dos } \\
\text { órgẫos } \\
\text { públicos/Capacita } \\
\text { çẫo de monitores } \\
\text { para serem } \\
\text { agentes } \\
\text { ambientais }\end{array}$ & curto & $\begin{array}{l}\text { PAMB/ } \\
\text { Prefeitura/ } \\
\text { DEPRN/IF }\end{array}$ & $\begin{array}{l}\text { Sapes/CBH- } \\
\text { LN/IF/Comuni } \\
\text { dade }\end{array}$ & Verbas Públicas \\
\hline Atividades agrícolas & $\begin{array}{l}\text { Elaborar projetos de } \\
\text { agricultura de baixo } \\
\text { impacto para áreas abaixo } \\
\text { da cota } 100\end{array}$ & $\begin{array}{l}\text { Implantação do projeto } \\
\text { de silvicultura ou } \\
\text { agrofloresta para } \\
\text { abandono dos cultivos } \\
\text { exóticos }\end{array}$ & $\begin{array}{l}\text { Criação de } \\
\text { cooperativas/ } \\
\text { Estudo detalhado } \\
\text { dos nichos de } \\
\text { mercado. }\end{array}$ & médio & $\begin{array}{l}\text { Secretaria da } \\
\text { agricultura e STR }\end{array}$ & $\begin{array}{l}\text { SAPES } \\
\text { /Unitau/ltesp }\end{array}$ & $\begin{array}{l}\text { Fehidro/FNMA/PR } \\
\text { ONAF }\end{array}$ \\
\hline Conservaçẫo da Bacia & $\begin{array}{l}\text { Elaborar projeto para } \\
\text { fossas ecológicas }\end{array}$ & $\begin{array}{l}\text { Atingir } 100 \% \text { dos } \\
\text { moradores }\end{array}$ & $\begin{array}{l}\text { Eliminar o } \\
\text { potencial de } \\
\text { poluiçẫo } \\
\text { /Proteçẫo do } \\
\text { manancial }\end{array}$ & médio & $\begin{array}{l}\text { Sabesp/Prefeitur } \\
\text { a/DAEE/ SMA }\end{array}$ & $\begin{array}{l}\text { CBH-LN/GT- } \\
\text { Rio Grande }\end{array}$ & $\begin{array}{l}\text { Prefeitura/SMA/As } \\
\text { sociaçã̃o de } \\
\text { Engenheiros de } \\
\text { Ubatuba }\end{array}$ \\
\hline Conservaçấo da Bacia & $\begin{array}{l}\text { Captaçẫo de água para } \\
\text { área abaixo da cota } 100 .\end{array}$ & $\begin{array}{l}\text { Eliminar a quantidade } \\
\text { de mangueiras para } \\
\text { captação e } \\
\text { desperdício de água }\end{array}$ & $\begin{array}{l}\text { Atingir } 100 \% \text { dos } \\
\text { moradores/ } \\
\text { Proteçã̃o do } \\
\text { manancial }\end{array}$ & médio & $\begin{array}{l}\text { Sabesp/Prefeitur } \\
\text { a/DAEE/ SMA }\end{array}$ & $\begin{array}{l}\text { CBH-LN/GT- } \\
\text { Rio Grande }\end{array}$ & $\begin{array}{l}\text { Prefeitura/SMAVAs } \\
\text { sociação dos } \\
\text { Engenheiros de } \\
\text { Ubatuba }\end{array}$ \\
\hline
\end{tabular}

Figura 4 - Matriz de planejamento - Proteção, conservação e geração de áreas degradadas 


\begin{tabular}{|c|c|c|c|c|c|c|c|}
\hline Tema & $\begin{array}{c}\text { Ações de } \\
\text { Melhoramento } \\
\text { Ambiental } \\
\end{array}$ & Atividades & Metas & Prazos & Responsáveis & $\begin{array}{c}\text { Entidades de } \\
\text { Apoio }\end{array}$ & $\begin{array}{c}\text { Fonte de } \\
\text { Finaciamento }\end{array}$ \\
\hline $\begin{array}{c}\text { Políticas Públicas } \\
\text { Municipais }\end{array}$ & $\begin{array}{c}\text { Priorizar a questẫo do } \\
\text { uso e ocupação do } \\
\text { solo. }\end{array}$ & $\begin{array}{c}\text { Discussẫo dos } \\
\text { problemas da Bacia } \\
\text { junto à Equipe } \\
\text { Plano Diretor do } \\
\text { Município }\end{array}$ & $\begin{array}{c}\text { Estabelecer uma } \\
\text { zona "especial" } \\
\text { para a área de } \\
\text { produçẫo hídrica da } \\
\text { bacia }\end{array}$ & curto & GT-Rio Grande & $\begin{array}{c}\text { GT-Rio } \\
\text { Grande/Câmara } \\
\text { Municipal/Prefei } \\
\text { tura }\end{array}$ & $x x$ \\
\hline $\begin{array}{l}\text { Legislaçã̃o } \\
\text { Ambiental } \\
\text { Manancial }\end{array}$ & $\begin{array}{l}\text { Fazer uma minuta de } \\
\text { legislação - Criação } \\
\text { "APA Municipal" entre } \\
\text { as cotas } 40-100 \text { e } \\
\text { estudar outros } \\
\text { instrumentos de } \\
\text { proteçẫo }\end{array}$ & $\begin{array}{c}\text { Apresentar em } \\
\text { audiênia pública }\end{array}$ & $\begin{array}{l}\text { Área de produçẫo } \\
\text { hídrica protegida }\end{array}$ & médio & $\begin{array}{l}\text { Câmara } \\
\text { Municipal }\end{array}$ & $\begin{array}{c}\text { GT-Rio } \\
\text { Grande/Câmara } \\
\text { Municipal/Prefei } \\
\text { tura }\end{array}$ & $x x$ \\
\hline $\begin{array}{c}\text { Zoneamento } \\
\text { Ambiental }\end{array}$ & $\begin{array}{c}\text { Elaboraçẫo de } \\
\text { Zoneamento e } \\
\text { Regulamentação de uso } \\
\text { da área de Manancial } \\
\text { (APA ou Uso Especial) }\end{array}$ & $\begin{array}{c}\text { Definir diretrizes de } \\
\text { ocupaçẫo }\end{array}$ & $\begin{array}{l}\text { zoneamento } \\
\text { estabelecido }\end{array}$ & médio & $\begin{array}{l}\text { Gt-Rio Grande, } \\
\text { IPEF, IF, ONG }\end{array}$ & $\mathrm{CBH}-\mathrm{LN}$ & $\begin{array}{c}\text { Fontes de } \\
\text { financiamento } \\
\text { externas }\end{array}$ \\
\hline $\begin{array}{l}\text { Caraterizaçẫo } \\
\text { sócioeconômico } \\
\text { dos moradores } \\
\text { situados à } \\
\text { montante da } \\
\text { captaçẫo } \\
\end{array}$ & $\begin{array}{l}\text { Caracterizçẫo da } \\
\text { questẫo fundiária }\end{array}$ & $\begin{array}{l}\text { Elaboraçẫo e } \\
\text { Aplicação de } \\
\text { questionário }\end{array}$ & $\begin{array}{c}\text { Traçar o perfil dos } \\
\text { moradores }\end{array}$ & curto & IPEF & $\begin{array}{l}\text { ITESP/GT-Rio } \\
\text { Grande }\end{array}$ & Fehidro \\
\hline $\begin{array}{c}\text { Elaborar o Plano } \\
\text { de Manejo }\end{array}$ & $\begin{array}{c}\text { Apresentar em } \\
\text { audiência pública }\end{array}$ & $\begin{array}{l}\text { Implantação do } \\
\text { Plano de manejo }\end{array}$ & $\begin{array}{c}\text { atividades } \\
\text { propostas serem } \\
\text { cumpridas } \\
\end{array}$ & longo & $\begin{array}{c}\text { IF/IPEF/PMU/Câ } \\
\text { mara }\end{array}$ & GT-Rio Grande & Fehidro \\
\hline $\begin{array}{c}\text { Preservação de } \\
\text { toda a Bacia }\end{array}$ & $\begin{array}{c}\text { Elaborar Plano de } \\
\text { Manejo para toda área } \\
\text { da Serra ao Mar }\end{array}$ & Elaborar projeto & $\begin{array}{c}\text { Projeto aprovado e } \\
\text { recurso finaneiro } \\
\text { disponibilizado }\end{array}$ & longo & GT-Rio Grande & \begin{tabular}{|c|} 
GT-Rio \\
$\begin{array}{c}\text { Grande/IPEF/IF/ } \\
\text { outros }\end{array}$ \\
\end{tabular} & Fehidro \\
\hline \begin{tabular}{|c|} 
Integraçẫo e \\
comprometimento \\
dos órgẫos \\
públicos \\
\end{tabular} & $\begin{array}{l}\text { Definir protocolos entre } \\
\text { órgẫos para agilizaçẫo } \\
\text { de açốes e resoluçổes }\end{array}$ & $\begin{array}{l}\text { Estabelecer } \\
\text { prioridades }\end{array}$ & $\begin{array}{c}\text { Açốes realizadas } \\
\text { com resultados } \\
\text { positivos }\end{array}$ & curto & $\begin{array}{c}\text { Prefeitura/Órgẫos } \\
\text { Estaduais }\end{array}$ & GT-Rio Grande & $x x$ \\
\hline $\begin{array}{l}\text { Melhoria na } \\
\text { fiscalização } \\
\text { preventiva e } \\
\text { repressiva }\end{array}$ & $\begin{array}{c}\text { Elaboraçẫo de um plano } \\
\text { de fiscalizaçẫo }\end{array}$ & $\begin{array}{c}\text { Inserir a prefeitura } \\
\text { municipal no } \\
\text { POC/PPMA e } \\
\text { estabelecer Plano } \\
\text { deTrabalho }\end{array}$ & $\begin{array}{l}\text { Termo de } \\
\text { cooperaçẫo para } \\
\text { realizaçẫo dos } \\
\text { trabalhos }\end{array}$ & curto & $\begin{array}{c}\text { S.A.U/DEPRN/IF } \\
\text { /PAMB }\end{array}$ & $\begin{array}{l}\text { IF/SAU/PAMB/ } \\
\text { Soc.Amigos } \\
\text { das Toninhas / } \\
\text { DEPRN }\end{array}$ & Sabesp/SNUC \\
\hline $\begin{array}{c}\text { Demarcaçẫo do } \\
\text { Parque }\end{array}$ & definir áreas prioritarias & $\begin{array}{c}\text { Encaminhamento } \\
\text { de ofícios } \\
\text { SMAVProcuradoria }\end{array}$ & $\begin{array}{c}\text { Áreas do entorno } \\
\text { do PESM } \\
\text { idendificada }\end{array}$ & curto & Câmara/CBH-LN & ITESP/IF & $\begin{array}{l}\text { Verbas } \\
\text { Estaduais }\end{array}$ \\
\hline $\begin{array}{c}\text { Datas } \\
\text { comemorativas }\end{array}$ & $\begin{array}{l}\text { Formaçẫo de uma } \\
\text { equipe de trabalho }\end{array}$ & $\begin{array}{c}\text { Definir data } \\
\text { importantes e tipo } \\
\text { de eventos } \\
\end{array}$ & $\begin{array}{l}\text { realização de } \\
\text { eventos com } \\
\text { perídicidade }\end{array}$ & curto & GT-Rio Grande & CBH-LN & Patrocínios \\
\hline
\end{tabular}

Figura 5 - Matriz de planejamento - Gestão 


\begin{tabular}{|c|c|c|c|c|c|c|c|}
\hline Tema & $\begin{array}{c}\text { Ações de } \\
\text { Melhoramento } \\
\text { Ambiental }\end{array}$ & Atividades & Metas & Prazos & Responsáveis & $\begin{array}{c}\text { Entidades de } \\
\text { Apoio }\end{array}$ & $\begin{array}{c}\text { Fonte de } \\
\text { Finaciamento }\end{array}$ \\
\hline Curso de capacitação & $\begin{array}{c}\text { Capacitar as diversas } \\
\text { instituiçốes, } \\
\text { educadores e } \\
\text { Associaçốes de } \\
\text { Moradores } \\
\end{array}$ & $\begin{array}{l}\text { acompanhar o } \\
\text { andamento do } \\
\text { Projeto junto ao } \\
\text { FEHIDRO }\end{array}$ & $\begin{array}{l}\text { Realizaçẫo de } 05 \\
\text { mini- cursos } 2002\end{array}$ & médio & IPEF / IF & GT-Rio Grande & FEHIDRO \\
\hline $\begin{array}{c}\text { Projetos de } \\
\text { educaçẫo ambiental }\end{array}$ & $\begin{array}{c}\text { Buscar parcerias junto } \\
\text { as ONGs para } \\
\text { desenvolverem projetos }\end{array}$ & $\begin{array}{c}\text { Apresentar o plano } \\
\text { para ONGs }\end{array}$ & $\begin{array}{c}\text { Um projeto de } \mathrm{E} . \mathrm{A} \\
\text { a cada ano } \\
\text { implantado }\end{array}$ & médio & $\begin{array}{l}\text { UNITAU/ESALQ/ } \\
\text { Universidades }\end{array}$ & $\begin{array}{c}\text { Prefeitura / GT } \\
\text { Rio Grande }\end{array}$ & FEHIDRO \\
\hline Divulgar na mídia & $\begin{array}{c}\text { Divulgação na Imprensa } \\
\text { semanalmente e } \\
\text { entrevista na Rádio para } \\
\text { conscientizaçẫo da } \\
\text { populaçẫo }\end{array}$ & $\begin{array}{l}\text { elaboração de } \\
\text { textos, firmar } \\
\text { compromisso com } \\
\text { a imprensa local }\end{array}$ & $\begin{array}{c}\text { Semanalmente } \\
\text { publicar matéria na } \\
\text { imprensa local }\end{array}$ & curto & GT- Rio Grande & $\begin{array}{c}\text { Jornal A } \\
\text { Semana/Rotary } \\
\text { ClubeUbatuba/ } \\
\text { Escolas- Rádio } \\
\text { Cidade Azul - } \\
\text { Igrejas } \\
\end{array}$ & $x x$ \\
\hline Divulgar na mídia & $\begin{array}{l}\text { Divulgar nos meios de } \\
\text { telecomunicaçốes }\end{array}$ & $\begin{array}{c}\text { elaboraçẫo de } \\
\text { textos, firmar } \\
\text { compromisso com } \\
\text { a imprensa local }\end{array}$ & $\begin{array}{l}\text { Duas matérias a } \\
\text { cada seis meses }\end{array}$ & curto & GT- Rio Grande & $\begin{array}{c}\text { TV Cultura/ TV } \\
\text { Globo/ Canal } \\
\text { Rural }\end{array}$ & $x x$ \\
\hline Divulgação & $\begin{array}{c}\text { Colocar Placas } \\
\text { informativas na área de } \\
\text { captaçẫo e de produçấo } \\
\text { de água }\end{array}$ & $\begin{array}{l}\text { Definir tipos de } \\
\text { placas e locais }\end{array}$ & $\begin{array}{l}\text { Area da bacia } \\
\text { sinalizada e } \\
\text { conhecida }\end{array}$ & curto & GT- Rio Grande & $\begin{array}{c}\text { IF, PMU, } \\
\text { Associação de } \\
\text { bairro }\end{array}$ & PMU \\
\hline
\end{tabular}

Figura 6 - Matriz de planejamento - Divulgação, capacitação e conscientização ambiental

O presente trabalho constitui, desta forma, uma contribuição e um avanço dessas interações, pois apresenta os resultados de uma das ações necessárias delineadas para a elaboração do Plano de Manejo, que é a caracterização hidrológica da bacia hidrográfica do Rio Grande de Ubatuba. 


\section{REVISÃO DA LITERATURA}

\subsection{Marco Legal}

O Código das Águas, Decreto $n^{\circ} 24.643$, publicado em 10 de julho de 1.934, era o único instrumento legal abrangente e específico sobre os recursos hídricos no País, até a publicação da Lei 9.433 em 1997, que institui a Política Nacional dos Recursos Hídricos (Brasil, 1997). Apesar das posturas corretas daquele decreto na disciplina do uso da água, na formulação do princípio para o uso múltiplo, nas preocupações com a saúde pública e a preservação da qualidade dos recursos hídricos, institucionalmente não conseguiu sobrepujar a setorização existente na administração pública brasileira (São Paulo,1977). Naquele instrumento legal, o recurso água dividia-se em três categorias: águas públicas, comuns e particulares. Com a promulgação da Constituição Federal em 1988, fica estabelecido que a partilha das águas é feita entre a União e os Estados Federados, desaparecendo, assim, as categorias de águas municipais e particulares.

Anteriormente à promulgação da Lei 9433/97, o Estado de São Paulo elaborou a Política Estadual dos Recursos Hídricos, o Sistema Integrado de Gerenciamento de Recursos Hídricos e o Fundo Estadual de Recursos Hídricos (FEHIDRO), por meio da Lei Estadual 7663 de 30 de dezembro de 1991 (Brasil,1991) que tem como foco principal o uso sustentável dos recursos hídricos, de forma a garantir a oferta adequada de água em quantidade e qualidade aos usuários atuais e seus descendentes. Adota a bacia hidrográfica como referência de gestão descentralizada, participativa e integrada, 
reconhecendo a água como bem público e compatibilizando o uso da água com o desenvolvimento regional e a proteção do meio ambiente (São Paulo, 1977).

A Política Nacional dos Recursos Hídricos toma como base a lei paulista, tendo como pontos comuns: a utilização racional das águas e sua prioridade para o abastecimento das populações, o aproveitamento múltiplo, a preservação e a proteção contra ações que possam comprometer seu uso atual e futuro e a gestão descentralizada, participativa e integrada com os demais recursos naturais e as peculiaridades da bacia hidrográfica. Ainda, da mesma forma que a lei paulista, institui o gerenciamento das bacias hidrográficas através dos comitês regionais.

Com base nesses instrumentos legais, foi criado em 1997 o Comitê de Bacias Hidrográfica do Litoral Norte (CBH-LN), que é uma das 23 Unidades de Gerenciamento de Recursos Hídricos (UGRH) do Estado de São Paulo e que abrange os municípios de Ubatuba, Caraguatatuba, São Sebastião e Ilhabela.

\subsection{Fundamentos Teóricos: a importância da floresta na produção de água}

\subsubsection{O ciclo hidrológico e a bacia hidrográfica}

O ciclo hidrológico é o fenômeno global de circulação fechada da água entre a superfície terrestre e a atmosfera, impulsionada fundamentalmente pela energia solar associada à gravitação e à rotação terrestre.

A superfície terrestre abrange os oceanos, os rios e lagos, os aqüíferos subterrâneos, as calotas polares, os solos saturados (áreas alagadas), rochas e os seres vivos.

A atmosfera também possui uma diversidade de condições físicas importantes, entretanto a maioria dos fenômenos meteorológicos acontece numa camada da atmosfera de cerca de 16 quilômetros, onde está contida a quase totalidade da umidade da atmosfera (troposfera). 
O intercâmbio entre as circulações da superfície terrestre e da atmosfera, fechando o ciclo hidrológico, ocorre nos dois sentidos: a) no sentido superfície atmosfera, em que o fluxo de água ocorre fundamentalmente na forma de vapor como decorrência a evapotranspiração ; b) no sentido atmosfera - superfície, em que a transferência de água ocorre em qualquer estado físico, sendo mais significativas, as precipitações de chuva e neve (Tucci, 2002).

A água é evaporada dos oceanos e da superfície continental e se torna parte da atmosfera. A umidade atmosférica precipita-se tanto nos oceanos como nos continentes. Nestes, a água precipitada pode ser interceptada pela vegetação, pode escoar pela superfície dos terrenos, ou pode infiltrar-se no solo, de onde pode ser transpirada pelas plantas, envolvendo vários e complicados processos hidrológicos como: evaporação, precipitação, interceptação, transpiração, infiltração, percolação, escoamento superficial (Lima, 1996).

O ciclo hidrológico só é fechado em nível global, e a água evaporada em um determinado local do planeta não precipita necessariamente no mesmo local, em função dos movimentos contínuos e com dinâmicas diferentes na atmosfera e na superfície terrestre. A Figura 7 apresenta a esquematização do ciclo da água. 


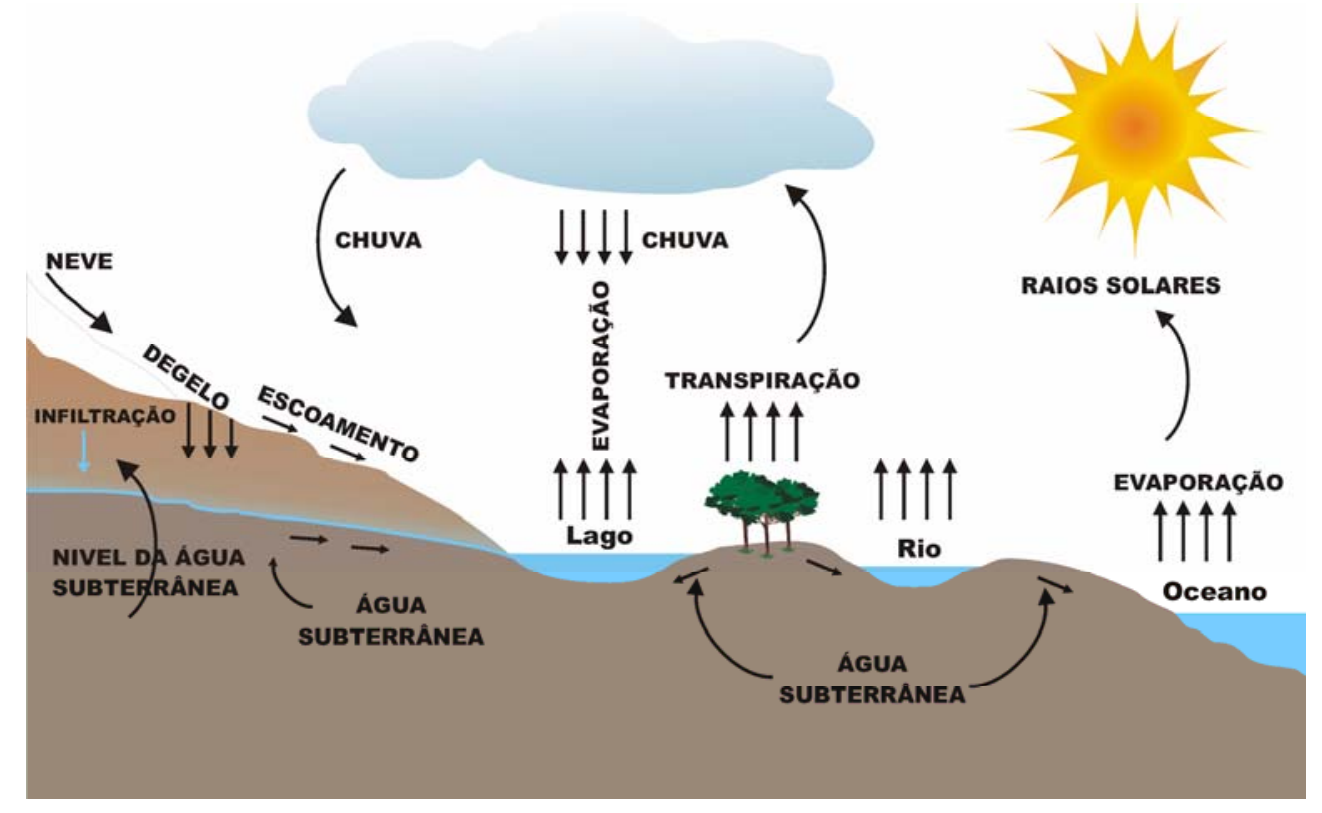

Figura 7 - Esquema do ciclo hidrológico

Uma bacia hidrográfica compreende toda a área de captação natural da água da chuva, que proporciona escoamento para o canal principal e seus tributários. O limite superior de uma bacia é o divisor de águas, ou seja, o divisor topográfico, e a delimitação inferior é a saída da bacia, isto é, sua confluência. O comportamento hidrológico de uma bacia hidrográfica é função de suas características morfológicas, ou seja, área, forma, topografia, geologia, solo, bem como a cobertura florestal (Lima, 1996).

Do ponto de vista hidrológico, as bacias hidrográficas são classificadas em grandes e pequenas, não com base em sua superfície total, mas nos efeitos de certos fatores dominantes na geração do deflúvio. Define-se "microbacia" como sendo aquela cuja área é tão pequena que a sensibilidade a chuvas de alta intensidade e às diferenças de uso do solo não seja suprimida pelas características da rede de drenagem (Lima \& Zakia, 2000).

A Lei Paulista $n^{\circ} 7663 / 91$, de Recursos Hídricos, adota o termo bacia hidrográfica como "unidade físico-territorial de planejamento e gerenciamento" 
(Brasil,1991) e, na Lei Federal $n^{\circ} 9.433 / 97$, a bacia hidrográfica é definida como a "unidade territorial para implementação da Política Nacional de Recursos Hídricos e atuação do Sistema Nacional de Gerenciamento de Recursos Hídricos" (Brasil, 1997).

Os rios são ecossistemas abertos em constante interação com o sistema terrestre e a atmosfera circundante. De acordo com Petts(2000), os rios devem ser vistos em três dimensões espaciais - longitudinal, lateral e vertical pronunciando mudanças físicas, químicas e biológicas. Eles são caracterizados por fortes processos hidrológicos e geomorfológicos, frente a mudanças climáticas e temporais. As três dimensões acima devem ser consideradas para a prática da conservação dos rios, acrescentando, ainda, as dimensões temporal e conceitual. A dimensão temporal é bastante significativa e importante, uma vez que a morfologia do canal de água e as comunidades aquáticas podem se alterar naturalmente, ao longo do tempo. Além disso, mudanças abruptas induzidas pelo homem, como represamento e lançamento de esgoto, podem alterar os processos a montante e a jusante.

Outras características principais dos rios são o nível e a profundidade da água, a cota do fundo, os leitos maior e menor, declividade e a vazão.A profundidade se refere à distância entre a superfície e o fundo do rio. A cota do fundo de uma seção é o seu ponto inferior na seção. O leito menor é a parte do rio onde o mesmo escoa na maioria do tempo (>95\% do tempo), e o leito maior é quando o rio escoa durante as enchentes mais raras. A cota do leito menor se refere ao risco da ordem de 2 a 5 anos de tempo de retorno, e o limite do leito maior é definido para um risco da ordem de 100 anos. A vazão é a quantidade de água que passa na seção por unidade de tempo.

\subsubsection{A influência da floresta na produção de água}

Qualquer ponto de uma superfície terrestre faz parte de uma bacia hidrográfica e sempre existe uma área discreta do terreno que capta a água da 
chuva, perde água por evaporação e produz o restante como deflúvio, ou seja, completa o balanço hídrico.

Os processos envolvidos no balanço hídrico de uma bacia hidrográfica podem ser observados na Figura 8.

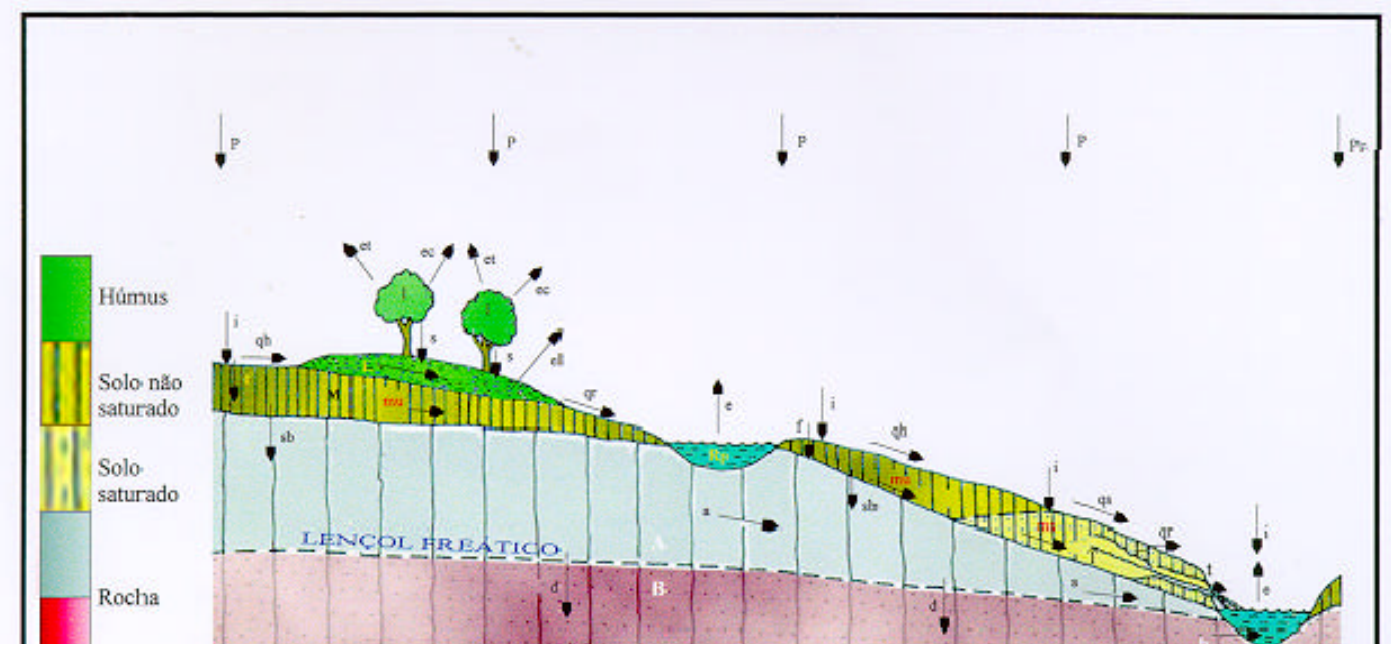

Precipitação total

Precipitação no curso d'água

Intensidade da chuva

Evapotranspiração

Evaporação da água interceptada pelas copas

Armazenamento de água nas copas

Escoamento pelo tronco e gotejamento

Escoamento pelo litter

Evaporação da água interceptada pelo litter

Armazenamento da água no litter

Evaporaçắo

Água armazenada nas depresš̃es Infiltração
P Escoamento hortoniano (superficial) $\quad q_{k}$

$\mathrm{P}_{c}$ Escoamento superficial de áreas saturadas $\mathrm{q}_{\text {s }}$

i Refluxo

$e_{1}$ "Pipe flow"

$\mathrm{e}_{\varepsilon}$ "Pipe storage"

I Escoamento subsuperficial não saturado

s Escoamento subsuperficial saturado

I Armazenamento de água no solo

e Percolação para a camada rochosa

L Fluxo na camada rochosa

e Zona de aeração

$R$, Percolação profunda.

f Escoamento base $\mathrm{q}_{\text {r }}$

t

T

$\mathrm{m}_{\text {. }}$

$\mathrm{m}$,

M

$\mathrm{S}_{\mathrm{b}}$

a

A

d

B

Figura 8 - Principais componentes do ciclo hidrológico em uma bacia hidrográfica (Zakia, 1998)

As florestas desempenham importante papel no regime hídrico de uma bacia hidrográfica. Segundo Lima (1993), uma microbacia hidrográfica, como um sistema natural aberto, funciona através de troca contínua de energia e 
matéria com o meio; e como ecossistema aberto de contornos bem definidos, ela não se encontra normalmente em equilíbrio. Ao contrário, sua dinâmica manifesta-se através de uma contínua condição transiente. Dessa forma, seu funcionamento é altamente complexo e bastante estável, tendo condições de suportar perturbações naturais, quando em boas condições de proteção florestal. Por outro lado, por essas mesmas razões, é altamente vulnerável a perturbações, quando algumas das interações dos processos hidrológicos internos são destruídas. As trocas de energia e matéria em uma bacia hidrográfica com o meio, assim como os processos hidrológicos internos que normalmente operam numa microbacia, podem ser visualizados na Figura 9, adaptada de Lima (1993).

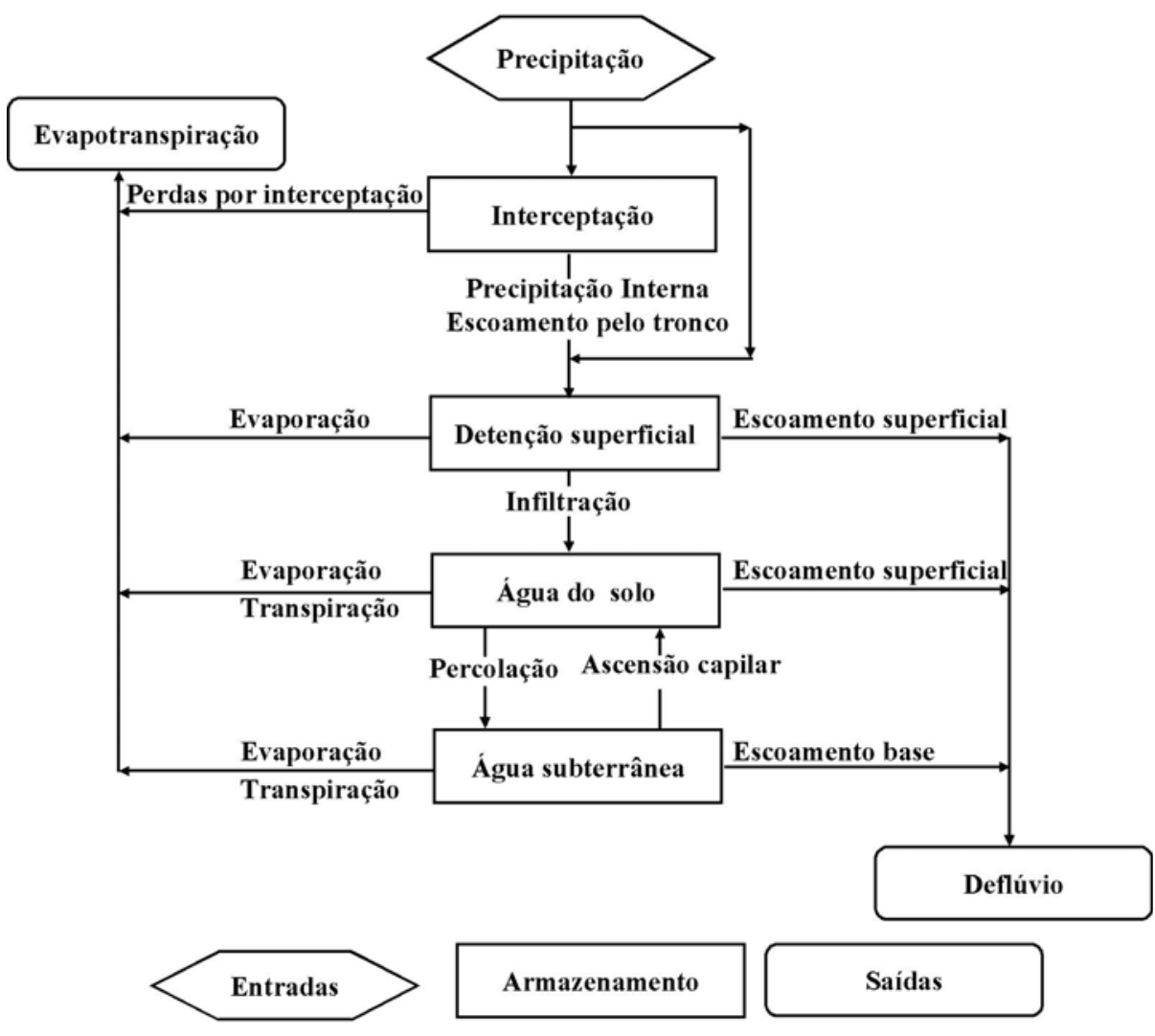

Figura 9 - Esquema dos processos hidrológicos em uma floresta (Adaptado de Lima,1993) 
A Figura 9 constitui a representação dos processos quantitativos do ciclo da água numa bacia florestada, desde a entrada no ecossistema pelas chuvas e a conseqüente interação dessa água com a copa da floresta, através do processo de interceptação, percorrendo uma série de processos internos de transferências ao longo de diversos compartimentos, até a saída final na microbacia. O deflúvio constitui o produto final dessas interações e representa a fração da chuva que resta, disponível para alimentar o escoamento dos cursos d'água (Lima,1996).

Diversos autores têm verificado que a presença da floresta em regiões montanhosas e em algumas regiões costeiras desempenha alguma influência na precipitação local, evidenciada na "precipitação oculta", principalmente em locais com temperaturas moderadas e elevados conteúdos de umidade influenciados pelos sistemas orográficos e pelos ventos carregados de umidade. A captação física da gotícula de água da neblina contribui positivamente no balanço hídrico local, aumentando a precipitação efetiva no local, o que não ocorreria se fosse medida convencionalmente (Vogelmann, 1973; Zadroga, 1981).

Estudo realizado por Anido (2002), no Núcleo Cunha do Parque Estadual da Serra do Mar, em microbacia com floresta natural (Mata Atlântica), indica que a precipitação oculta, que é a entrada adicional da água captada no processo de captura de neblina pelo dossel floresta, é de $8 \%$, em função da freqüente ocorrência de neblina.

A interceptação da chuva é outro efeito importante desempenhado pela floresta e exerce uma importância significativa dentro do contexto do balanço hídrico de um determinado local, uma vez que a floresta é responsável pela diminuição no total de chuva que atinge o piso florestal. Vários estudos têm sido conduzidos sobre a influência da floresta no recebimento (interceptação) e redistribuição da chuva. Entende-se por redistribuição da chuva a água que goteja ao solo, a água que escoa pelo tronco das árvores e a água que retorna à atmosfera por evaporação direta. 
Durante um período sem chuva, a transpiração e a evaporação direta da água do solo compõem o consumo total de água por uma superfície vegetada. Durante períodos chuvosos, todavia, a interceptação também passa a fazer parte das perdas de água pelo ecossistema. A perda por interceptação resulta da evaporação da água da chuva que fica retida temporariamente na copa..

Por outro lado, o corte raso da floresta, além do efeito significativo sobre a diminuição da transpiração, pode acarretar, também, modificações no microclima da área cortada, com possíveis efeitos sobre a hidrologia local em termos de escoamento superficial, erosão e ciclagem de nutrientes.

Segundo Lima (1996), estudos em florestas tropicais sugerem que as perdas por interceptação são responsáveis pela redução de $50 \%$ na precipitação total incidente em florestas tropicais da Malásia. Outros estudos realizados na mesma região mostraram que as perdas por interceptação variam de 25 a $80 \%$ da precipitação incidente.

Vários estudos na área de manejo de bacias hidrográficas têm sido realizados pelo Instituto Florestal em parceria com a Japan International Cooperation Agency (JICA) no Laboratório de Hidrologia Florestal Eng. Agr. Walter Emmerich, na região de Cunha, em área recoberta com vegetação nativa da Mata Atlântica. Trabalho publicado por Cicco et al.(1985), nessas condições, mostra os seguintes percentuais de precipitação interna, escoamento pelo tronco e perda por interceptação, relativos à precipitação incidente: $80,2 \%, 1,1 \%$ e $18,7 \%$.

No contexto de balanço hídrico, o conhecimento das taxas anuais de evapotranspiração é de grande importância, uma vez que o rendimento hídrico de uma bacia é afetado pelo consumo total de água pela vegetação. Este componente de balanço hídrico pode mesmo suplantar a produção de água da bacia (Lima,1996).

Cicco et al.(1989) estudaram a estimativa da evapotranspiração na microbacia hidrográfica $D$, com floresta natural da Mata Atlântica, no Parque Estadual da Serra do Mar, para o período de um ano hídrico, e avaliaram que a 
taxa de evapotranspiração correspondeu a $10,46 \%$ da precipitação total na bacia, e o escoamento total correspondeu a $89,54 \%$. Outro dado importante refere-se ao escoamento básico, que foi de $1.973,50 \mathrm{~mm}$, para um escoamento total de $2.722,40 \mathrm{~mm}$.

Outro estudo conduzido no mesmo local por Arcova et al.(1998), realizado para um período de 06 anos em duas microbacias, ambas recobertas com vegetação nativa, demonstrou que a produção hídrica da área é bastante elevada, perfazendo cerca de cerca de $70 \%$ de toda a água que chega às microbacias em forma de chuva, em decorrência das baixas taxas evaporativas da região. De acordo com Arcova et al.(1998), "as microbacias da região são conservativas quanto ao consumo de água, em comparação com outras de clima tropical, uma vez que a evapotranspiração anual da Mata Atlântica do local é relativamente baixa".

O conhecimento da influência da floresta sobre a água no solo é importante para o planejamento de um manejo adequado para uma dada bacia hidrográfica. O solo florestal apresenta normalmente boas condições de infiltração, e as áreas florestadas constituem importantes fontes de abastecimento de aqüíferos.

Em regiões montanhosas, a drenagem mais eficiente da água subsuperficial limita o armazenamento da água subterrânea. A presença da floresta nessas regiões é responsável pela manutenção de taxas ótimas de infiltração de água no solo e, conseqüentemente, de alimentação do lençol freático (Lima, 1996).

A cobertura florestal é um dos importantes fatores que influi sobre a condição superficial do solo, pois a presença da vegetação e da camada de material orgânico, a serrapilheira, fornece proteção contra o impacto das gotas de chuva, reduzindo a compactação e desagregação. Por outro lado, se as condições de transmissão de água através do perfil do solo (percolação) não são satisfatórias, as taxas de infiltração poderão ser prejudicadas. O horizonte superficial do solo pode tornar-se impermeável por vários motivos, tais como: o 
tráfego intenso, pisoteio exagerado, cultivo ininterrupto e outros. A compactação do solo reduz sua porosidade total, sendo que áreas cultivadas apresentam menor infiltração que áreas adjacentes florestadas. A presença da vegetação é particularmente importante na manutenção das condições de porosidade do solo, quer pelo desenvolvimento das raízes, quer pela matéria orgânica adicionada.

Conceitualmente, a expressão produção de água (deflúvio) refere-se à descarga total de uma bacia por um determinado período de tempo. Os componentes do deflúvio são: o escoamento direto e o escoamento base. $O$ deflúvio é influenciado por três grupos de fatores: clima, fisiografia e uso do solo. Os fatores climáticos influenciam o deflúvio por meio da precipitação e evapotranspiração. A quantidade, intensidade, duração, distribuição espacial e temporal, a freqüência, a forma e o tipo são algumas das características das chuvas que afetam o deflúvio.

De acordo com Cicco \& Fujieda (1999), "o uso do solo, nele incluindo o tipo de vegetação e as atividades antropogênicas, afeta a formação do deflúvio pela sua influência na evapotranspiração, infiltração de água para o interior do solo e percolação da água na bacia. Este fator, sem dúvida alguma, é dos mais relevantes a ser considerado no manejo de bacias hidrográficas, pois, dependendo do tipo de vegetação e das práticas utilizadas pelo homem. o deflúvio pode ser modificado de maneira favorável ou prejudicial para os usuários da bacia hidrográfica".

Nas áreas urbanas, as modificações naturais e artificiais da cobertura vegetal têm vários efeitos sobre o ciclo hidrológico como: aumento de escoamento médio e superficial, tendo como conseqüência o aumento das enchentes, redução da evaporação e do escoamento subterrâneo, aumento da produção de sedimentos e material sólido, degradação da qualidade das águas pluviais e contaminação dos aqüíferos (Tucci \& Clarke, 1998).

Segundo Lima (1996), um experimento pioneiro utilizando método hidrométrico, isto é, a medição da fase terrestre do ciclo da água, em 
microbacias experimentais, foi realizado na região de Wagon-Wheel Gap, no Estado do Colorado, no ano de 1910. Duas bacias ( \pm 80ha cada), adjacentes e florestadas, foram instrumentadas para medição precisa da precipitação e deflúvio. Durante um período inicial, em que ambas permaneceram inalteradas do ponto de vista da cobertura florestal, os dois processos hidrológicos precipitação deflúvio foram medidos para obtenção da equação de calibração de uma microbacia em função da outra. Ao término deste período uma das bacias recebeu o tratamento experimental, o corte raso da floresta. $O$ resultado mostrou que a microbacia que recebeu o corte raso da floresta obteve um aumento do deflúvio médio anual, ou seja, da produção de água de $25,5 \mathrm{~mm}$, em comparação com a microbacia testemunha.

Bormann \& Likens (1970) conduziram, em New Hampstire, USA, na floresta experimental de Hubbard Brook, um experimento em seis bacias hidrográficas. Numa das bacias, com 15,6 ha, eliminaram toda a vegetação florestal e compararam com outra bacia não desmatada. Através dessa comparação, verificaram que a bacia experimental desmatada apresentou aumento no deflúvio e na concentração de nutrientes.

Hibbert (1967) analisou o resultado de trinta e nove estudos em diferentes regiões do mundo sobre o efeito da alteração da cobertura florestal na produção de água.De um modo geral, os trabalhos mostraram que: a) redução da cobertura florestal aumenta a produção de água; b) o estabelecimento de cobertura florestal em áreas com vegetação esparsa diminui produção de água; c) a resposta aos tratamentos apresentam enorme variabilidade. Por exemplo, o corte raso da floresta e a queimada do subbosque das montanhas rochosas do Colorado causaram um aumento de apenas $34 \mathrm{~mm}$ no deflúvio anual. Entretanto, nas montanhas do Leste da África Ocidental, o corte raso da floresta aumentou o deflúvio anual em $457 \mathrm{~mm}$. Ainda, nessa revisão realizada pelo autor, foi verificado que o aumento do deflúvio ocorre principalmente no primeiro ano após o tratamento e está correlacionado com outros fatores como a precipitação, evapotranspiração, e 
outras variáveis. Geralmente a maior produção de água está associada com a maior precipitação. $O$ declínio no aumento da produção de água começa a aparecer logo após o tratamento, quando ocorre a revegetação.

O conhecimento ainda incompleto dos mecanismos pelos quais a microbacia reage à ocorrência de uma chuva, através do escoamento direto, é uma das grandes contribuições das pesquisas em microbacias experimentais. Esta área de estudos tem sido tão intensa a ponto de resultar no desenvolvimento de uma nova área de conhecimento - a Hidrologia de Vertentes (Lima \& Zakia, 2000).

Desde os trabalhos pioneiros de Horton, publicados a partir de 1933, prevaleceu a teoria de que o escoamento direto era basicamente produzido pelo escoamento superficial que ocorre toda vez que a intensidade da chuva excede a capacidade de infiltração do solo, e que toda a água da chuva que se infiltra no terreno alimenta o lençol freático, para depois deixar a microbacia na forma de escoamento base. Mais ainda, segundo esta teoria, o escoamento superficial assim gerado (hoje referido como escoamento superficial hortoniano) provinha de todas as partes da microbacia (Chorley, 1978).

Segundo Ward(1984), essa teoria era baseada em três considerações: a) a capacidade de infiltração é definida como a taxa máxima de absorção da água superficial. Essa magnitude começa com um valor máximo no início da chuva e logo diminui, conforme a compactação da superfície pela ação das gotas, o preenchimento coloidal dos interstícios do solo, saturação nas camadas superiores;b) o solo atua como um plano de separação hidrológica entre os volumes que geram "escoamento rápido e escoamento lento"; c) é formada uma lâmina de água que se acumula sobre a superfície e escoa sobre um plano hipotético.

O conceito de "área variável de afluência" foi estabelecido por Hewlett \& Hibbert (1967), através de estudo de hidrogramas de microbacias experimentais de regiões montanhosas. O desenvolvimento deste conceito deveu-se ao fato de que, nestas microbacias revestidas de boa cobertura florestal, o escoamento 
direto não é produzido ao longo de toda a superfície da microbacia. Ao contrário, o escoamento direto nestas condições está sob a influência de uma área de origem dinâmica, uma vez que sofre expansões e contrações (daí o nome "área variável"), e que normalmente representa apenas uma fração pequena da área total da microbacia (Lima \& Zakia, 2000). 

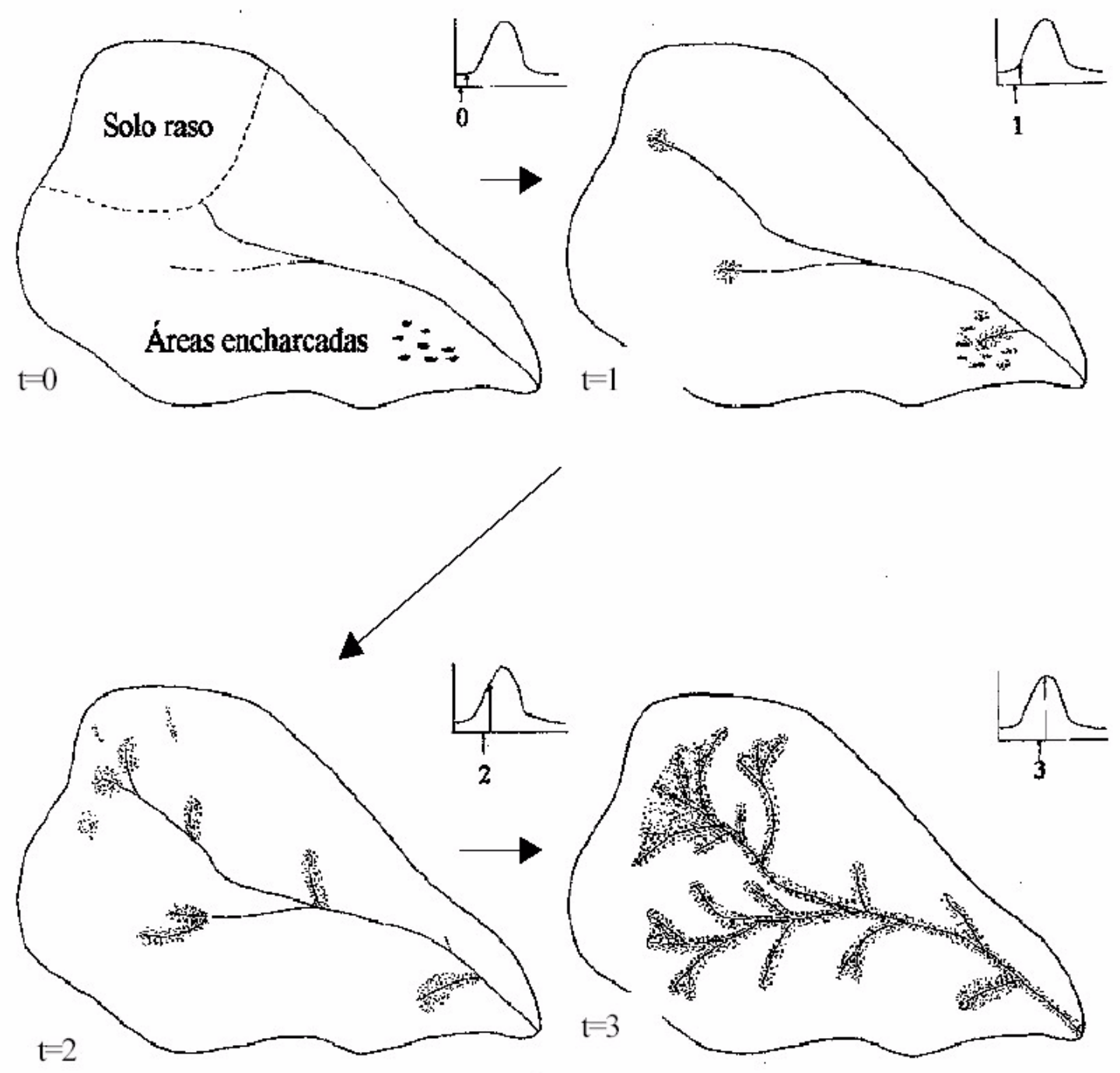

Figura 10 - Visualização do conceito de "área variável de afluência" (AVA) na geração do deflúvio em microbacias (Hewlett \& Hibbertt, 1967)

O preceito básico do conceito de área variável de afluência é que a água das chuvas geralmente infiltra-se nos solos florestais não perturbados, migra no sentido da declividade e mantém os solos na porção inferior das vertentes em condições de saturação ou próximo a este estado de umidade. Essas regiões contribuem prontamente com o fluxo subsuperficial para o escoamento direto como zona dos solos saturados. Essas áreas se expandem lateralmente e 
longitudinalmente, sendo que o grau de saturação e subseqüente expansão variam em função das condições de umidade antecedente do solo e do volume de duração da chuva (Hibbert \& Troendle, 1988).

Em extensa revisão bibliográfica sobre o assunto, Lima (1989) relaciona as áreas para geração do escoamento rápido de microbacias florestadas: a) zonas saturadas que margeiam os cursos d'água e suas cabeceiras, as quais podem se expandir durante chuvas prolongadas, isto é, as zonas ripárias; b) concavidades do terreno, para as quais há convergência das linhas de fluxo, como as concavidades freqüentemente existentes nas cabeceiras e que também fazem parte da zona ripária; c) áreas de solo raso, com baixa capacidade de infiltração. Nos dois primeiros casos, o processo que ocorre é o escoamento superficial das áreas saturadas, presentes mesmo quando a intensidade de chuva é inferior à capacidade de infiltração do solo, sendo que parte desse processo pode ser derivado do interfluxo lateral (escoamento subsuperficial). $O$ terceiro caso refere-se ao escoamento superficial propriamento dito (escoamento Hortoniano) (Arcova, 1999).

Segundo Kobyama et al.(1998), trabalhos posteriores aos de Hewlett, aprofundaram-se na localização das áreas saturadas e nos mecanismos internos das vertentes. Assim foram monitoradas bacias cujos resultados demonstram de forma clara que as áreas saturadas poderiam ocorrer em lugares afastados dos cursos naturais. Essas áreas distantes têm conexões com partes baixas do vale e contribuem com escoamento rápido para os canais através de caminhos preferenciais e fluxo interno do solo. Segundo o autor, um dos mecanismos internos é o fluxo através de macroporos, nos quais importantes volumes de água tomam um caminho preferencial com relação ao sistema restante, produzindo um tempo de resposta bem menor que através da matriz do solo, interconectando rapidamente as camadas de solo afetadas.

Beven \& Germann (1982) definiram vários tipos: a) os poros formados pela fauna; (ii) os poros formados pelas raízes das plantas; b) fissura e rachaduras; e c) condutos naturais dentro do solo (piping). O terceiro grupo 
está composto freqüentemente pelo dessecamento dos solos argilosos e devido as técnicas de plantio convencionais, como o subsolamento. O piping é um tipo especial de macroporos, cujo desenvolvimento é dado no sentido da declividade da vertente.

Segundo Kobyama et al. (1998), é praticamente impossível separar a geração do escoamento superficial do subsuperfical devido às condições de saturação do solo. O escoamento excedente, devido à saturação, é uma mistura de fluxo de retorno, "efeito pistão" e escoamento produzido pela chuva que não infiltra no terreno saturado. O escoamento base é o escoamento da zona de saturação, ou seja, água subterrânea. É o componente do deflúvio que predomina nos períodos de estiagens.

O papel hidrológico importante desempenhado pela floresta é dado pela capacidade de infiltração da água no solo, que faz com que alimente o escoamento base, regularizando a vazão dos rios durante todo o período do ano.

Estudos de balanço hídrico anual realizados no período de seis anos, em duas microbacias experimentais " $B$ " e " $D$ ", ambas recobertas com vegetação de Mata Atlântica, realizados no Laboratório de Hidrologia Florestal Eng. Agr. Walter Emmerich, na região Cunha, SP, mostram que a produção de água no período das chuvas supera em apenas $10 \%$ o período seco, concluindo que a floresta é conservativa em termos de consumo de água, por apresentar um regime de descarga bastante regular durante todo o ano (Arcova \& Cicco, 1997).

\subsubsection{Modelos hidrológicos}

O modelo hidrológico é uma ferramenta que a ciência desenvolveu, para melhor entender e representar o comportamento da bacia hidrográfica e prever condições diferentes das observadas. É usado nos programas de pesquisas em bacias hidrográficas para estruturar dados, estudar as respostas do local, 
selecionar e avaliar parâmetros, determinar a precisão usada na entrada de variáveis e parâmetros, estudar a significância da variabilidade espacial e temporal das características físicas e determinar observações necessárias para encontrar um grau de precisão em um período especifico de tempo (De Coursey, 1985). É utilizado também para antecipar os eventos, representando o impacto da urbanização de uma bacia antes que ela ocorra, e medidas preventivas possam ser tomadas. Pode ser utilizado para previsão de uma enchente em tempo real; ocorrência de eventos extremos estatisticamente possíveis; impactos da alteração de um rio como derivações e construções de barragens.

Dooge (1973) conceitua um sistema como qualquer estrutura ou procedimento, real ou abstrato, que num dado tempo de referência interrelaciona-se com uma entrada, causa ou estímulo de energia, e uma saída, efeito ou respostas de energia.

Algumas definições são importantes para melhor compreender o sistema e modelos que o representa:

- Fenômeno: é um processo físico que produz alteração de estado no sistema. Ex: precipitação, evapotranspiração, infiltração.

- Variável: é um valor que descreve quantitativamente um fenômeno, variando no espaço e no tempo. Por exemplo, vazão é uma variável que descreve o estado do escoamento.

- Parâmetro: é um valor que caracteriza o sistema, que também pode variar no espaço e no tempo. Exemplos de parâmetros são: rugosidade de uma seção de um rio, a área de uma bacia hidrológica, as áreas impermeáveis de uma bacia.

A simulação é o processo de utilização de modelo, existindo em geral três fases: uma de calibração (ou ajuste do modelo), outra de validação (ou verificação) e previsão. A calibração ou estimativa de parâmetros é fase de simulação em que os parâmetros são determinados; a verificação (ou validação) é a simulação do modelo com os parâmetros estimados em que se 
verifica a validade do ajuste realizado; e a previsão é a simulação do sistema pelo modelo com parâmetros ajustados para quantificação de suas respostas a diferentes entradas. $O$ ajuste de parâmetros depende da disponibilidade dos dados históricos, medições da amostra, e determinação da característica física do sistema.

De acordo com Tucci (1998), os métodos utilizados para as estimativas de parâmetros são:

a) estimativas sem dados históricos: quando não existem dados sobre as variáveis do sistema, pode-se estimar os valores dos parâmetros baseando -se em informações das características do sistema. Em geral, cada parâmetro possui um intervalo de variação possível, obtido pela literatura.

b) ajuste por tentativas: é o processo em que existindo valores das variáveis de entrada e saída, são obtidos por tentativa os parâmetros que melhor representem os valores observados através do modelo utilizado.

c) Ajuste por otimização: utiliza os mesmos dados do processo por tentativa, mas, por métodos matemáticos, otimiza uma função objetiva que retrata a diferença entre os dados observados e calculados pelo modelo.

Segundo Cleary(1998), os modelos alargam informações, mas não produzem números inquestionáveis. Eles tentam representar uma versão simplificada do que freqüentemente é um sistema complexo. Assim, seus resultados são imperfeitos. De qualquer modo, quando se usa em conjunto com experiências e com dados de campo, eles ajudam a tomar decisões técnicas melhor do que seria possível por outros meios. Eles são particularmente úteis, quando muitas alternativas são comparadas dentro de uma mesma idéia (dados, parâmetros físicos estimados, etc), de modo que, enquanto os dados numéricos de qualquer alternativa única podem não ser exatos, os resultados comparativos, mostrando que uma alternativa é superior a várias outras, são usualmente válidos. 
Um sistema pode ser classificado de acordo com critérios estabelecidos na literatura, assim como o modelo que representa um sistema. Nem sempre um sistema é representado por um modelo de mesmas características. $O$ comportamento de um sistema pode ser linear ou não-linear. Um sistema é linear, quando as propriedades de homogeneidade e superposição são satisfeitas.

Um modelo é concentrado ("lumped"), quando não leva em conta a variabilidade espacial. A precipitação média de uma bacia é um exemplo de integração espacial de variável de entrada.O modelo distribuído ("distrïbuted"), quando as variáveis e parâmetros do modelo dependem do espaço e do tempo.

Uma das principais classificações de sistemas e modelos na simulação hidrológica é se são estocásticos ou determinísticos. A abordagem determinística relaciona causa e efeito e geralmente envolve parâmetros de característica física. Segundo Righetto (1998), a modelagem, obtida exclusivamente da aplicação das leis físicas, é composta de modelos determinísticos, de modo que o resultado das simulações realizadas através desses modelos pode ser repetido, quando se utilizam os mesmos dados de entradas. $O$ autor exemplifica que um modelo determinístico de transformação de chuva em vazão fornecerá exatamente o mesmo hidrograma enquanto forem utilizados os mesmos valores para os parâmetros do modelo e a mesma chuva ou ietograma.

De acordo com Chow (1964), quando a chance de ocorrência das variáveis é levada em conta e o conceito de probabilidade é introduzido na formulação do modelo, o processo e o modelo são ditos estocásticos.

Um modelo é dito conceitual, quando as funções utilizadas na sua elaboração levam em conta os processos físicos, enquanto os modelos empíricos ajustam os valores calculados aos dados observados através de função que não tem nenhuma relação com os processos físicos envolvidos. 
Segundo Tucci (1998), a definição de modelo conceitual é artificial, já que as funções empíricas são também usadas (como por exemplo as equações de Horton e de Darcy) e estão relacionadas com a física do sistema.

Passos (1993) elaborou um diagrama que facilita a compreensão da classificação dos modelos hidrológicos (Figura 11).

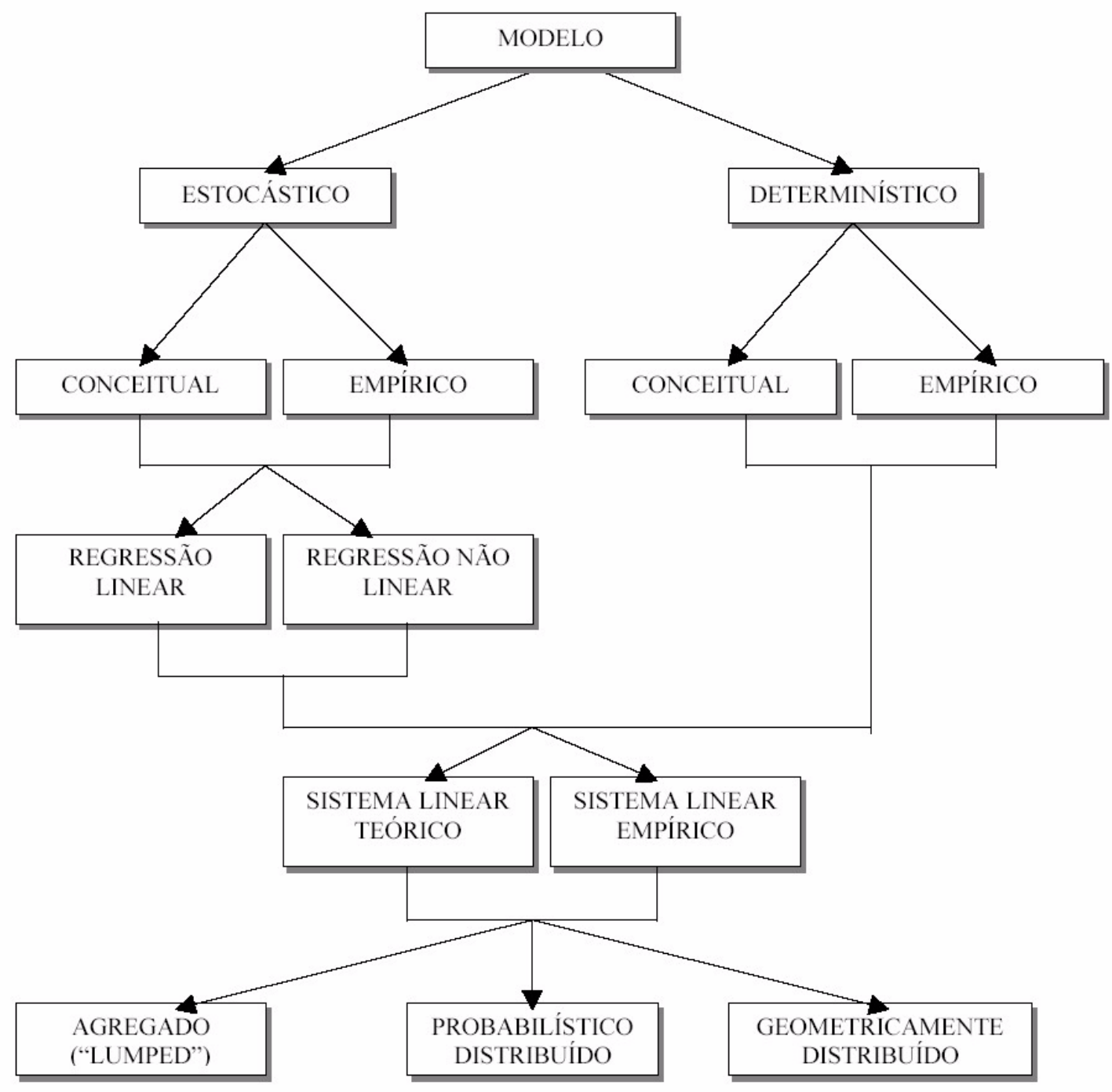

Figura 11 - Classificação de modelos hidrológicos (Passos, 1993)

Até a década de 50 do século passado, os métodos utilizados na hidrologia limitavam-se a indicadores estatísticos dos processos envolvidos. Com o advento dos computadores e aprimoramento de técnicas numéricas e 
estatísticas, houve o desenvolvimento acelerado dos modelos de transformação de chuva-vazão.

Nas últimas décadas, os modelos hidrológicos se desenvolveram em dois sentidos: a) modelos para grandes bacias tratam de forma empírica a distribuição dos parâmetros em área de grande magnitude; b) modelos para pequenas bacias que buscam representar com maior precisão, de forma distribuída, os processos hidrológicos (Tucci, 1998).

O modelo SMAP "Soil Moisture Accounting Procedure" de simulação hidrológica do tipo transformação chuva-vazão desenvolvido por Lopes et. al. (1982) apresenta estrutura simples, para séries continuas, e utiliza a separação do escoamento baseada nos parâmetros do Departamento de Conservação do Solo Norte- Americano - Soil Conservation Service (SCS). É um modelo determinístico, conceitual e agregado. O desenvolvimento do modelo baseou-se na experiência com a aplicação do modelo Stanford Watershed IV e modelo Mero em trabalhos realizados no DAEE - Departamento de Águas e Energia Elétrica do Estado de São Paulo. Foi originalmente desenvolvido para intervalo de tempo diário e, posteriormente, apresentado em versão horária e mensal, adaptando-se algumas modificações em sua estrutura. Necessita de dados de chuva, evaporação de tanque classe $A$ e vazões médias para um período mínimo necessário para a calibração .

A Calibração do Modelo SMAP pode ser realizada através de dois métodos: a) de forma manual, através de "tentativa e erro", exigindo, no entanto, muita experiência do hidrólogo para determinação de cada parâmetro; b) através de métodos matemáticos de otimização para calibração automática, que nesse caso facilita o trabalho de técnicos menos experientes e diminui a subjetividade do processo manual. A desvantagem da calibração automática é que acarreta a falta de acompanhamento do hidrólogo na calibração passo a passo dos parâmetros, impedindo o desenvolvimento da sua sensibilidade, e com isso, diminuindo a confiabilidade dos resultados. Os procedimentos rotineiros de execução do modelo estão detalhados no capitulo Métodos. 


\section{MATERIAL E MÉTODO}

\subsection{Material}

\subsubsection{Caracterização geral da bacia do Rio Grande}

O município de Ubatuba localiza-se na coordenadas geográficas $23^{\circ} 26^{\text {" }}$ $09^{\prime \prime}$ de latitude sul e $45^{\circ} 04^{\prime}$ ' $10^{\prime \prime}$ de latitude oeste, com área territorial de 711 $\mathrm{Km}^{2}$.

O Diagnóstico da Situação Atual dos Recursos Hídricos (IPT, 2000) faz uma delimitação geográfica do município de Ubatuba dividindo-o em 33 subbacias. Essa divisão foi feita em função da peculiaridade da região, pois o direcionamento das drenagens parte das porções mais altas da serra em direção ao oceano, formando várias drenagens principais. O Rio Grande de Ubatuba está inserido na sub-bacia 7, que é composta pelos cursos d'água que partem das porções mais elevadas da Serra do Mar e drenam em direção ao Oceano Atlântico, e compreende as áreas de drenagens dos rios Grande de Ubatuba, o Rio da Lagoa e o Rio Acaraú, os quais deságuam, respectivamente, nas praias Iperoig e do Itaguá. Existem também pequenas drenagens que deságuam na Praia Grande e das Toninhas, e outras que drenam os costões rochosos entre a Ponta das Toninhas e a Ponta do Espio. Essas drenagens perfazem 102,6 $\mathrm{Km}^{2}$. A sub bacia 7 é a segunda maior bacia em volume de água no município de Ubatuba, apresentando vazão de $5,23 \mathrm{~m}^{3} / \mathrm{s}$, perdendo apenas para a sub-bacia 3 , situada na porção norte do município e 
denominada Quiririm - Poruba, que possui área de $166,4 \mathrm{Km}^{2}$ e vazão de $8,20 \mathrm{~m}^{3} / \mathrm{s}$. A Figura 12 apresenta a localização da bacia.

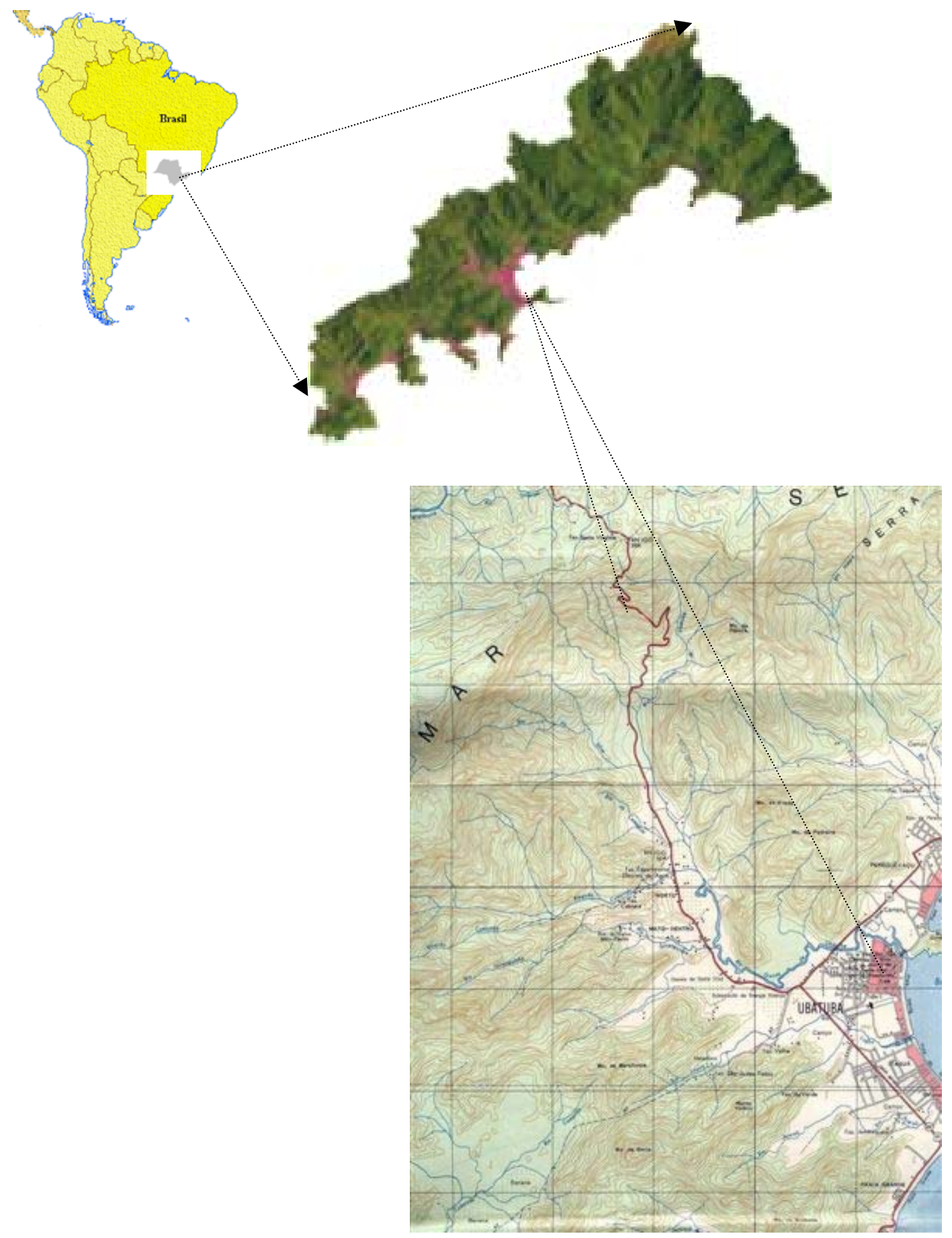

Figura 12 - Localização do município de Ubatuba com destaque para a bacia do Rio Grande ( IBGE, 1981) 
As nascentes e os cursos d'água formadores do Rio Grande encontramse na parte alta do Parque Estadual da Serra do Mar, criado pelo Decreto Estadual 10.251/77 (Brasil,1977), alterado pelo Decreto Estadual 13.313/79 (Brasil, 1979), tendo sido considerado como Unidade de Proteção Integral pelo Sistema Nacional de Unidade de Conservação (SNUC), instituído pela Lei Federal 9.985/00 (Brasil, 2000b).

O Instituto Florestal é o órgão responsável pela administração do parque, que abriga o maior remanescente de Mata Atlântica do Estado de São Paulo, com área de cerca de 315.000ha. Em função da grande extensão territorial da unidade de conservação, foram criados oito núcleos regionais. O parque ocupa $76,30 \%$ da área territorial do município de Ubatuba, ou seja, $543 \mathrm{Km}^{2}$, e é administrado pelo Núcleo Picinguaba.

A região foi reconhecida pela UNESCO como Reserva da Biosfera da Mata Atlântica, no programa "Man and Biosphere", colocando-a como um patrimônio da humanidade de importância internacional.

A área da Bacia do Rio Grande de Ubatuba, que é objeto deste estudo, possui cerca de $26 \mathrm{Km}^{2}$, medida a partir do ponto de captação localizado na coordenada UTM $7412722 \mathrm{~S}$ e $487824 \mathrm{~W}$ e, destes $26 \mathrm{Km}^{2}$, cerca de $22 \mathrm{Km}^{2}$ encontram-se dentro da área do Parque.

Monteiro(1973) faz uma classificação climática do território Paulista, estando a área de estudo na zona costeira sazonalmente controlada pelos sistemas equatoriais e tropicais configurando-se regionalmente os chamados "Climas úmidos das costas expostas à massa tropical atlântica", formando a Unidade Litoral Norte. Segundo o autor, a área está menos sujeita à participação das massas polares (30 a $40 \%$ de participação anual) e menos freqüentemente sujeito, às invasões de frio que os outros setores da Zona Costeira, mas a Serra do Mar bem próxima à costa é responsável pela acentuada pluviosidade da região, mesmo na estação seca. Além da complexidade da dinâmica atmosférica, outros fatores influenciam a distribuição espacial das chuvas na região, como as características dos compartimentos 
geomorfológicos (amplitude e orientação do relevo), declividade das vertentes, entre outros. As chuvas mais intensas estão relacionadas às áreas de vertentes íngremes nas partes mais elevadas da encosta.

De acordo com os dados pluviométricos registrados no Instituto Agronômico - Seção Agrícola da Estação Experimental de Ubatuba, na parte baixa da Bacia do Rio Grande para o período de 1935 a 2001, a precipitação média anual é de $3.200 \mathrm{~mm}$.

Com relação à temperatura média anual, não ocorrem grandes variações ao longo do ano, ficando a temperatura média anual em torno de $22,6{ }^{\circ} \mathrm{C}$, variando de $17,85^{\circ} \mathrm{C}$ até $27,35^{\circ} \mathrm{C}$.

Quanto aos aspectos geomorfológicos, a bacia encontra-se inserida na Província Costeira, possuindo duas zonas geomorfológicas distintas: a Serrania Costeira e as Baixadas Litorâneas. A Serrania Costeira corresponde à área da bacia drenada diretamente para o mar, constituindo o rebordo do Planalto Atlântico. A delimitação do Planalto Atlântico e da Serrania Costeira ocorre através da Serra do Mar.

De acordo com o Diagnóstico da Situação Atual dos Recursos Hídricos (IPT, 2000), a Serra do Mar apresenta um quadro morfológico relacionado aos efeitos de um tectonismo regional e de sucessivas fases erosionais. Trata-se de uma área resultante de dobramentos, reativações de falhas e remobilizações de blocos crustais. A topografia reflete esses condicionamentos geológicos, onde ocorrem, em toda a sua extensão, vales alongados, segmentos de drenagem retilíneos, linhas de cristas e cumeadas paralelas, relevos com grandes desníveis altimétricos e escarpas íngremes.

Apresenta também relevo de transição denominado Escarpas Festonadas. Neste compartimento geomorfológico predominam amplitudes maiores que $1000 \mathrm{~m}$ e declividades de encostas superiores a $30 \%$. As Escarpas Festonadas correspondem à porção da Serra do Mar em contato com a linha de borda do Planalto Atlântico. Este relevo exibe drenagem de alta densidade com espigões que avançam em direção às baixadas ou planícies costeiras. Essas 
escarpas geralmente apresentam vertentes com perfis retilíneos e se desfazem em anfiteatros separados por espigões com topos angulosos.

A área de estudo apresenta formação florestal denominada Floresta Ombrófila Densa e está inserida no domínio da Mata Atlântica estabelecida pelo Decreto Federal $n^{\circ} 750 / 93$ (Brasil,1993a). A vegetação nativa encontra-se em estágio avançado de regeneração na sua maior porção.

De acordo com os parâmetros de caracterização da vegetação nativa estabelecidos pela Resolução CONAMA $n^{\circ}$ 10, de $1^{\circ}$ de outubro de 1993 (Brasil,1993b), e pela Resolução CONAMA nº 001, de 31 de janeiro de 1994 (Brasil,1994), a Floresta Ombrófila Densa apresenta fisionomia florestal fechada, formando um dossel contínuo, com árvores emergentes. A diversidade biológica é muito grande devido à complexidade estrutural. Apresenta estratos herbáceo, arbustivo e arbóreo bem definidos. A distribuição diamétrica é de grande amplitude e a camada de serapilheira é abundante, variando em função do tempo e da localização e com intensa decomposição. Apresenta epifitas e trepadeiras lenhosas em grandes números de espécies e com grande abundância. As espécies arbóreas mais comuns são os jequitibás, jatobás, pau-marfim, guarantã, figueira, mulungu, guanandi, pixirica, pau-d'alho, peroba, jacarandá, palmito, aroeira, guapuruvu, cedro, canjerana, açoita-cavalo, óleo-de-copaíba, canafístula, canelas, araribá, ipês, angelim, marinheiro, mandiocão, pau-jacaré, guaiuvira, angicos. No estrato herbáceo predominam as bromélias, marantas e as helicôneas.

\subsubsection{Uso do solo}

A bacia caracteriza-se por possuir grande parte recoberta com floresta nativa, conforme apresentada na Figura 13. 


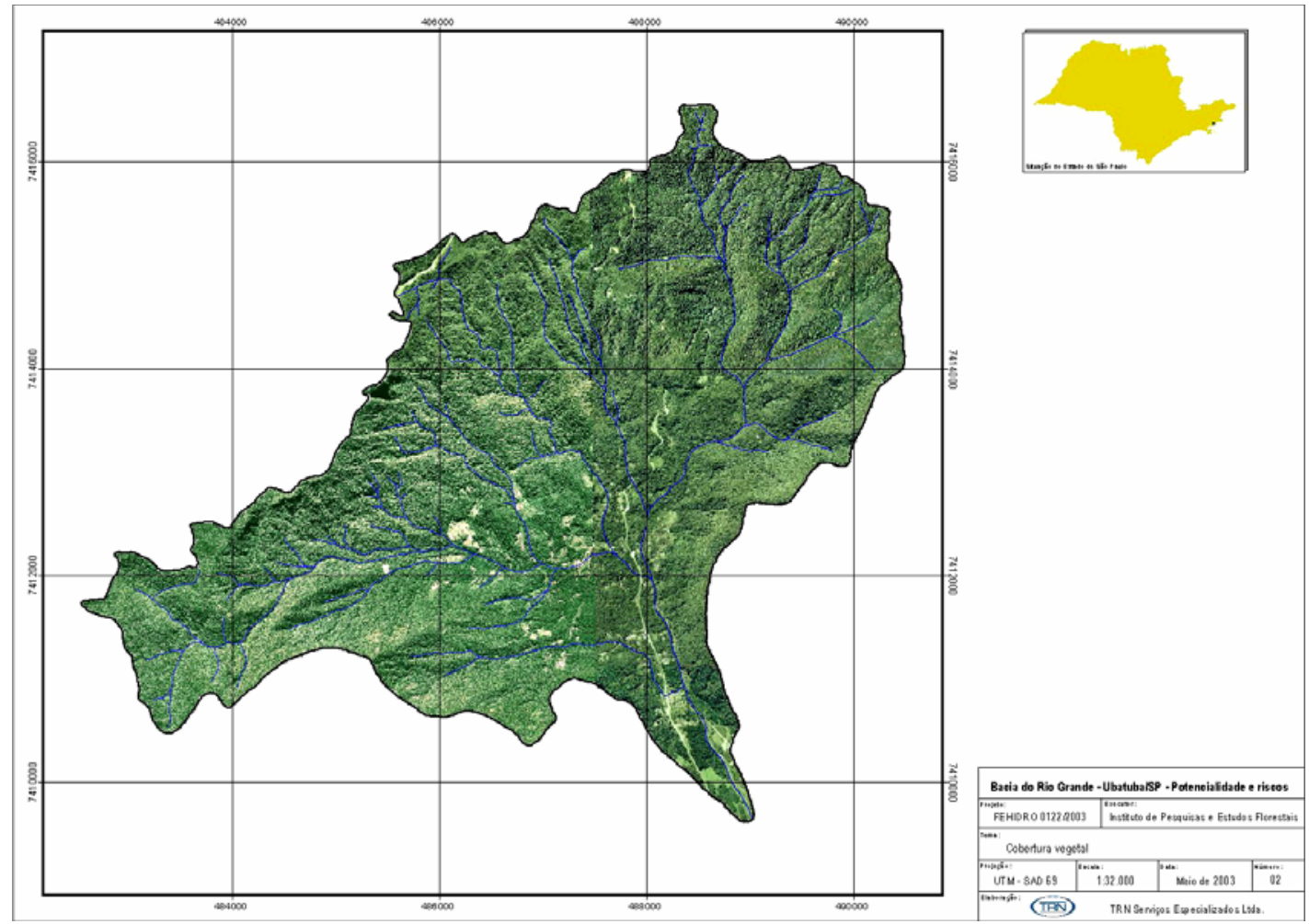

Figura 13 - Mapa da cobertura florestal na bacia do Rio Grande (Fonte TRN ${ }^{1}$ )

Entre a cota altimétrica de $400 \mathrm{~m}$ até o topo da Serra, no divisor de água, a vegetação encontra-se bastante preservada.

Entre a cota $100 \mathrm{~m}$ e $400 \mathrm{~m}$ existe um aglomerado urbano rarefeito com característica mista de urbana e rural, com aproximadamente 90 áreas ocupadas. O uso predominante da área é para moradia, porém um grande número de casas é usado para lazer (sítio de recreio e veraneio). O uso com

\footnotetext{
${ }^{1}$ Tecnologia em Recursos Naturais.
} 
agricultura de subsistência e criação de animais representa apenas $13 \%$ das áreas ocupadas. Esta região da bacia insere no interior do Parque Estadual da Serra do Mar, caracterizando uma ocupação ilegal. A região não é atendida por serviços públicos como coleta de lixo, energia elétrica, manutenção de sistema viário, e saneamento básico (coleta de esgoto e distribuição de água)2.

Entre a cota altimétrica $40 \mathrm{~m}$ e $100 \mathrm{~m}$, região da bacia situada acima do ponto de captação de água e abaixo da linha divisória do PESM, já possui características de região urbana consolidada. Existem aproximadamente 300 moradias e apresenta alguns pontos comercias. A região é atendida por serviços de coletas de lixo, meio de transporte com linha regular de ônibus urbano, e energia elétrica. Não existe atendimento público de coleta de esgoto e distribuição de água. Não existe ordenamento do espaço público, e a ocupação é caracterizada como irregular, pois o parcelamento de solo ocorre em desacordo com a Lei 6.766/79, que disciplina o parcelamento do solo urbano (Brasil, 1979).

A captação de água para abastecimento das residências é realizada através de colocação de mangueiras nos afluentes do Rio Grande. Em algumas propriedades existem fossas sépticas, e em outras, o esgoto é lançado diretamente nos afluentes do Rio Grande. Não existe sistema adequado de condução das águas pluviais.

\subsubsection{Censo e a taxa de crescimento populacional do município de Ubatuba}

Ubatuba apresenta forte vocação turística determinada por suas características geográficas, associadas aos aspectos sociais e econômicos. Como conseqüência desse fato, a cidade conta com a presença de uma população flutuante significativa durante os meses do verão, em feriados

2 Barreto, K.D., levantamento socioeconômico da bacia do Rio Grande de Ubatuba,2002. Relatório interno .Informações coletadas no âmbito dos trabalhos do GT Rio Grande de Ubatuba. 
prolongados e nos finais de semanas. A economia voltada ao setor turístico tem como resultado um grande fluxo migratório de mão-de-obra para a região.

De acordo com os dados da Fundação Instituto Brasileiro de Geografia e Estatística (IBGE) e Fundação Sistema Estadual de Análise de Dados (SEADE), a população residente é estimada em 70.952 habitantes, e a taxa de crescimento anual (taxa média geométrica de incremento anual da população brasileira) é de $5,18 \%$ aa para o período de 1980 a 1991 e de 3,97 \% aa para o período de 1991 a 2000.

\subsection{Método}

\subsubsection{A delimitação da bacia}

A delimitação da bacia do Rio Grande (Figura 14) foi feita a partir do ponto de captação de água da SABESP (Figura 15), com o auxílio do Arc View 3.2, utilizando-se a base cartográfica do Sistema Cartográfico do estado de São Paulo, na escala 1:10.000. 


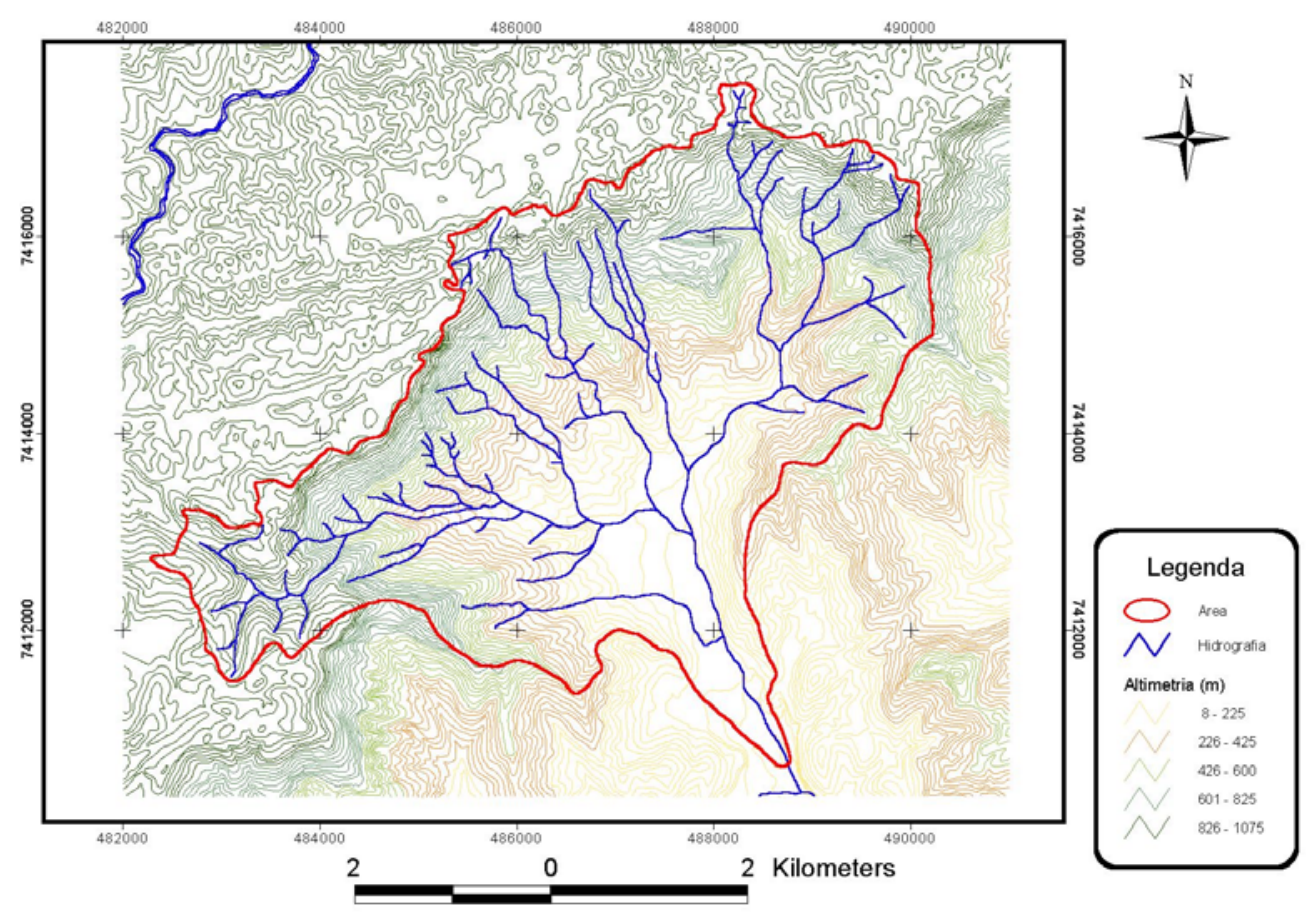

Figura 14 - Delimitação da bacia do Rio Grande de Ubatuba sobre a base cartográfica 1:10.000 do Estado de São Paulo

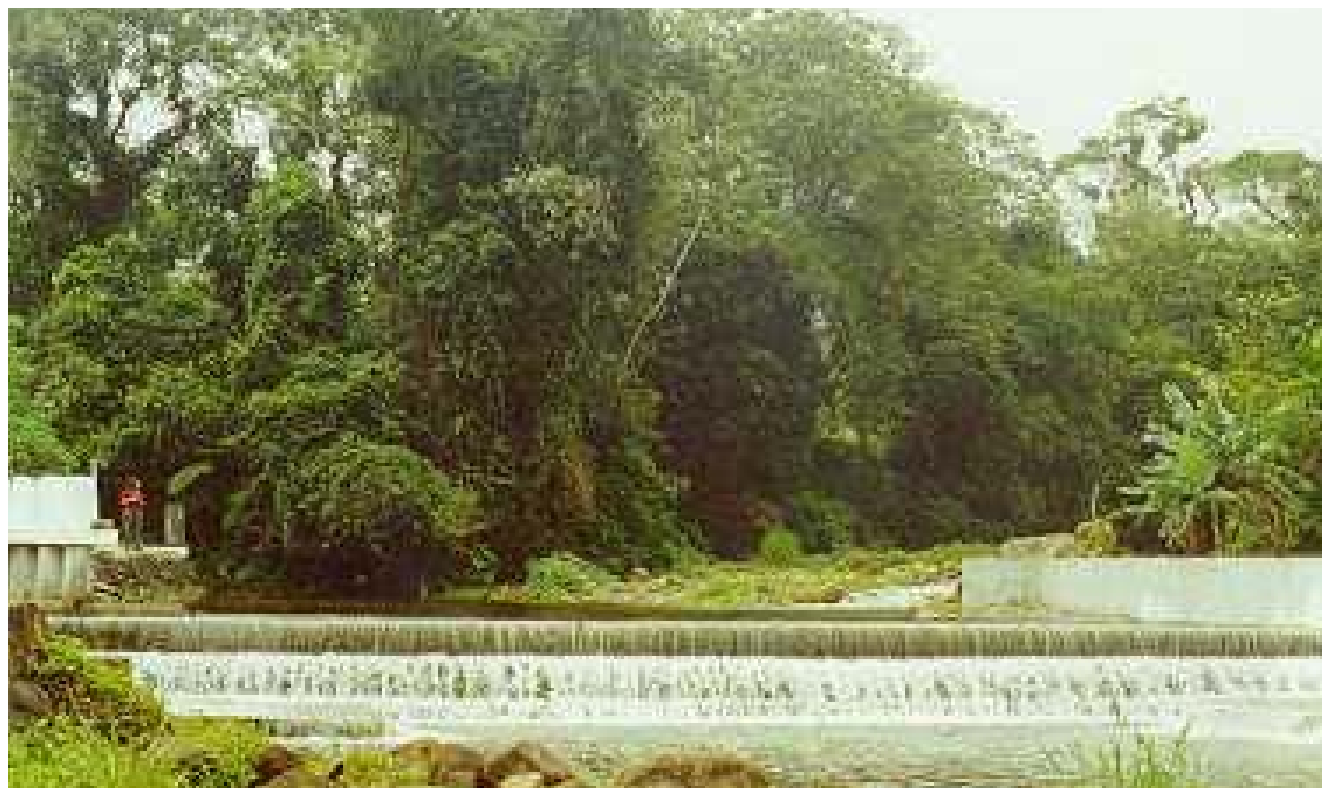

Figura 15 - Foto do ponto de captação de água na bacia o Rio Grande de Ubatuba 


\subsubsection{Dados de vazão (Q)}

Para a calibração da bacia foram utilizados os dados de vazão média mensal $(\mathrm{Q})$ pertencente à rede de monitoramento do Departamento de Águas e Energia Elétrica (DAEE), mais especificamente, os dados do Posto Prefixo 2E041 (Prefixo DNAEE 80010000), instalado no bairro Mato Dentro, no Rio Grande de Ubatuba. Neste ponto, localizado na latitude $23^{\circ} 26^{\prime} 05^{\prime \prime} \mathrm{S}$ e longitude $45^{\circ} 05^{\prime} 07^{\prime \prime} \mathrm{W}$., a área de drenagem da bacia é de $64 \mathrm{Km}^{2}$. O período de monitoramento realizado pelo DAEE foi de fevereiro de 1972 até fevereiro de 1975, conforme Tabela 1.

Tabela 1. Série de Vazão média mensal $\left(\mathrm{m}^{3} / \mathrm{s}\right)$ monitorada pelo DAEE de $1972 \mathrm{a}$ 1975

\begin{tabular}{lllllllllllll}
\hline \multicolumn{1}{c}{ jan } & fev & mar & abr & mai & jun & jul & ago & set & out & nov & dez \\
\hline 1972 & - & 4,84 & 4,93 & 4,22 & 3,18 & 2,72 & 2,55 & 2,53 & 4,16 & 5,61 & 5,19 & 4,41 \\
1973 & 10,28 & 8,44 & 5,13 & 5,03 & 6,92 & 2,84 & 4,66 & 2,37 & 3,82 & 4,15 & 5,51 & 6,79 \\
1974 & 8,89 & 3,44 & 2,40 & 2,46 & 1,73 & 1,43 & 0,97 & 0,74 & - & 1,16 & 0,86 & 3,55 \\
1975 & 5,21 & 6,40 & - & - & - & - & - & - & - & - & - & - \\
\hline
\end{tabular}

\subsubsection{Precipitação}

Os dados de precipitação mensal $(P)$ e de temperatura média mensal $(T)$ do ar foram adquiridos junto à Seção de Climatologia Agrícola do Instituto Agronômico de Campinas, no Posto da Estação Experimental de Ubatuba, localizado na latitude $23^{\circ} 27^{\prime} \mathrm{S}$ e longitude $45^{\circ} 04^{\prime} \mathrm{W}$, altitude $8 \mathrm{~m}$. A série histórica de chuvas utilizada no estudo foi a correspondente ao período de 1935 a 2001(Tabela 2). 
Tabela 2. Total de chuva mensal $(\mathrm{mm})$ no período de 1935 - 2001.Instituto Agronômico - Seção de Climatologia Agrícola da Estação Experimental de Ubatuba

\begin{tabular}{|c|c|c|c|c|c|c|c|c|c|c|c|c|c|}
\hline Ano & jan & fev & mar & $a b r$ & mai & jun & jul & ago & set & out & nov & dez & Anual \\
\hline 1935 & 297,7 & 675,4 & 279,2 & 220,0 & 159,2 & 156,8 & 433,6 & 296,0 & 278,5 & 177,1 & 170,8 & 296,3 & 3440,6 \\
\hline 1936 & 315,1 & 521,8 & 583,0 & 128,3 & 227,2 & 212,3 & 16,2 & 91,2 & 203,2 & 170,7 & 135,9 & 274,3 & 2879,2 \\
\hline 1937 & 449,3 & 151,3 & 121,2 & 237,9 & 200,0 & 24,5 & 70,0 & 110,2 & 38,0 & 243,9 & 339,9 & 347,7 & 2333,9 \\
\hline 938 & 235,7 & 563,9 & 189,6 & 333,3 & 89,1 & 270,3 & 140,8 & 245,9 & 174,9 & 205,8 & 327,9 & 349,2 & 3126,4 \\
\hline 1939 & 347,5 & 107,5 & 929,3 & 417,5 & 154,1 & 35,6 & 75,5 & 23,6 & 194,6 & 95,4 & 185,3 & 404,4 & 2970,3 \\
\hline 1940 & 505,0 & 300,8 & 323,1 & 180,2 & 76,9 & 41,2 & 35,4 & 49,4 & 141,3 & 348,6 & 333,4 & 325,9 & 2661,2 \\
\hline 1941 & 246,6 & 650,5 & 763,9 & 123,6 & 125,5 & 71,1 & 117,8 & 72,5 & 219,1 & 109,4 & 315,2 & 519,0 & 3334,2 \\
\hline 1942 & 252,5 & 241,1 & 253,8 & 255,9 & 66,6 & 70,5 & 102,5 & 76,3 & 123,9 & 452,2 & 446,1 & 287,7 & 2629,1 \\
\hline 1943 & 416,5 & 175,1 & 206,6 & 166,5 & 182,4 & 100,2 & 33,6 & 383,9 & 87,2 & 328,2 & 207,1 & 549,0 & 2836,3 \\
\hline 1944 & 328,7 & 573,1 & 284,4 & 529,2 & 177,3 & 41,2 & 130,5 & 42,5 & 130,0 & 136,3 & 527,5 & 265,1 & 3165,8 \\
\hline 1945 & 515,3 & 425,3 & 383,4 & 427,0 & 119,1 & 256,4 & 62,6 & 55,0 & 288,8 & 96,7 & 199,7 & 466,1 & 3295,4 \\
\hline 1946 & 365,7 & 210,2 & 542,5 & 262,6 & 121,4 & 46,3 & 45,6 & 111,2 & 239,6 & 500,1 & 201,5 & 277,1 & 2923,8 \\
\hline 1947 & 689,6 & 39,5 & 230,4 & 194,5 & 171,1 & 201,3 & 175,8 & 251,8 & 262,3 & 369,2 & 321,8 & 519,2 & 3426,5 \\
\hline 1948 & 310,4 & 577,5 & 369,7 & 157,3 & 224,7 & 65,3 & 220,3 & 81,9 & 168,5 & 167,8 & 354,2 & 236,5 & 2934,1 \\
\hline 1949 & 715,0 & 153,2 & 231,6 & 105,3 & 45,6 & 349,9 & 263,6 & 209,0 & 194,2 & 166,8 & 139,9 & 317,5 & 2891,6 \\
\hline 1950 & 787,7 & 244,6 & 423,2 & 282,7 & 186,9 & 39,8 & 14,4 & 69,6 & 278,6 & 298,4 & 443,5 & 412,5 & 3481,9 \\
\hline 1951 & 531,4 & 498,2 & 638,9 & 208,5 & 56,6 & 10,3 & 51,4 & 99,5 & 22,6 & 342,3 & 223,0 & 307,8 & 2990,5 \\
\hline 1952 & 673,8 & 775,1 & 338,3 & 88,6 & 54,3 & 168,8 & 95,4 & 108,2 & 266,7 & * & * & * & 2569,2 \\
\hline 1953 & 98,6 & 237,8 & 285,0 & 162,1 & 65,0 & 23,4 & 59,1 & 292,8 & 81,7 & 158,6 & 362,2 & 236,6 & 2062,9 \\
\hline 1954 & 56,8 & 150,3 & 345,7 & 148,9 & 138,6 & 57,4 & 115,4 & 55,7 & 176,0 & 292,8 & 150,8 & 290,9 & 1979,3 \\
\hline 1955 & 318,8 & 73,7 & 270,5 & 120,3 & 59,4 & 42,3 & 41,5 & 52,2 & 101,5 & 132,4 & 181,3 & 151,9 & 1545,8 \\
\hline 1956 & 77,4 & 218,8 & 365,2 & 166,2 & 89,4 & 145,1 & 34,1 & 78,3 & 74,4 & 235,3 & 143,9 & 129,3 & 1757,4 \\
\hline 1957 & 184,9 & 305,3 & 217,4 & 216,2 & 31,9 & 42,1 & 37,4 & 45,3 & 230,7 & 244,7 & 165,6 & 179,8 & 1901,3 \\
\hline 1958 & 256,3 & 182,2 & 243,8 & 234,3 & 207,0 & 98,6 & 28,2 & 103,5 & 130,6 & 295,3 & 659,7 & 452,5 & 2892,0 \\
\hline 1959 & 293,4 & 854,4 & 280,9 & 84,5 & 166,6 & 11,1 & 42,5 & 135,6 & 120,7 & 142,6 & 296,3 & 306,8 & 2735,4 \\
\hline 1960 & 397,5 & 672,5 & 234,6 & 123,7 & 82,6 & 55,5 & 92,4 & 172,7 & 111,0 & 331,0 & 244,9 & 524,0 & 3042,4 \\
\hline 1961 & 709,0 & 656,6 & 397,0 & 188,7 & 91,0 & 86,2 & 340,2 & 36,7 & 145,2 & 91,3 & 115,9 & 219,0 & 3076,8 \\
\hline 1962 & 417,0 & 576,6 & 246,8 & 189,1 & 132,9 & 18,3 & 70,4 & 61,4 & 200,8 & 357,4 & 277,6 & 695,9 & 3244,2 \\
\hline
\end{tabular}


Tabela 2. Total de chuva mensal $(\mathrm{mm})$ no período de 1935 - 2001.Instituto Agronômico - Seção de Climatologia Agrícola da Estação Experimental de Ubatuba

\begin{tabular}{|c|c|c|c|c|c|c|c|c|c|c|c|c|c|}
\hline Ano & jan & fev & mar & $a b r$ & mai & jun & jul & ago & set & out & nov & dez & Anual \\
\hline 1963 & 149,5 & 203,0 & 433,9 & 26,5 & 110,5 & 77,3 & 49,0 & 96,2 & 21,9 & 253,6 & 325,2 & 136,9 & 1883,5 \\
\hline 1964 & 194,8 & 331,6 & 204,4 & 146,3 & 132,1 & 117,9 & 142,6 & 107,3 & 76,8 & 259,7 & 351,1 & 349,9 & 2414,5 \\
\hline 1965 & 379,1 & 275,3 & 288,7 & 344,0 & 284,9 & 139,3 & 120,0 & 37,4 & 205,4 & 183,8 & 192,6 & 692,1 & 3142,6 \\
\hline 1966 & 688,4 & 354,6 & 236,9 & 628,6 & 192,8 & 28,9 & 269,7 & 194,9 & 120,2 & 334,0 & 293,8 & 509,0 & 3851,8 \\
\hline 1967 & 646,0 & 507,6 & 958,5 & 249,3 & 49,8 & 125,3 & 127,6 & 64,4 & 244,0 & 377,2 & 238,8 & 265,6 & 3854,1 \\
\hline 1968 & 165,2 & 169,1 & 183,7 & 272,2 & 63,7 & 74,6 & 164,2 & 108,3 & 157,4 & 267,3 & 163,5 & 310,7 & 2099,9 \\
\hline 1969 & 396,4 & 401,8 & 226,5 & 169,9 & 98,3 & 112,6 & 124,8 & 142,6 & 101,1 & 257,0 & 717,2 & 390,0 & 3138,2 \\
\hline 1970 & 295,4 & 340,7 & 211,0 & 90,3 & 69,4 & 215,0 & 126,0 & 101,4 & 90,9 & 185,9 & 59,2 & 95,0 & 1880,2 \\
\hline 1971 & 105,2 & 356,5 & 273,3 & 180,9 & 181,7 & 69,0 & 81,1 & 272,9 & 107,4 & 114,4 & 224,5 & 380,7 & 2347,6 \\
\hline 1972 & 152,5 & 303,5 & 183,0 & 196,9 & 13,0 & 27,0 & 42,0 & 120,0 & 245,0 & 332,0 & 236,0 & 213,0 & 2063,9 \\
\hline 1973 & 571,6 & 291,5 & 152,5 & 140,7 & 306,0 & 55,0 & 390,0 & 85,0 & 291,0 & 208,0 & 415,0 & 508,1 & 3414,4 \\
\hline 1974 & 564,9 & 20,0 & 107,0 & 113,0 & 97,0 & 70,0 & 61,7 & 65,0 & 133,2 & 112,0 & 120,0 & 333,4 & 1797,2 \\
\hline 1975 & 488,7 & 413,1 & 132,7 & 131,1 & 151,8 & 49,1 & 70,7 & 35,7 & 117,7 & 275,3 & 465,2 & 347,4 & 2678,5 \\
\hline 1976 & 671,3 & 368,9 & 294,9 & 194,7 & 204,3 & 50,4 & 143,2 & 146,2 & 268,8 & 218,2 & 116,6 & 356,6 & 3034,1 \\
\hline 1977 & 357,4 & 16,7 & 72,5 & 377,1 & 50,5 & 52,3 & 40,4 & 129,5 & 359,3 & 223,9 & 260,1 & 342,6 & 2282,3 \\
\hline 1978 & 368,3 & 293,2 & 159,1 & 155,7 & 94,9 & 59,9 & 36,2 & 19,3 & 34,0 & 76,6 & 204,8 & 271,8 & 1773,8 \\
\hline 1979 & 305,9 & 138,0 & 632,8 & 248,3 & 90,4 & 55,6 & 86,5 & 78,7 & 208,2 & 93,7 & 309,3 & 534,0 & 2781,4 \\
\hline 1980 & 499,2 & 360,7 & 134,7 & 250,0 & 10,0 & 78,9 & 60,2 & 140,7 & 79,5 & 317,0 & 245,0 & 238,3 & 2414,2 \\
\hline 1981 & 676,6 & 137,1 & 446,6 & 419,6 & 61,2 & 82,0 & 103,2 & 106,8 & 97,1 & 135,7 & 342,1 & 362,7 & 2970,7 \\
\hline 1982 & 301,8 & 154,0 & 419,2 & 177,6 & 27,1 & 141,7 & 72,3 & 116,4 & 199,7 & 220,8 & 340,9 & 384,5 & 2556,0 \\
\hline 1983 & 202,7 & 182,6 & 408,6 & 282,5 & 287,6 & 176,4 & 43,4 & 43,0 & 280,4 & 169,2 & 129,9 & 336,1 & 2542,4 \\
\hline 1984 & 280,4 & 72,7 & 195,9 & 137,8 & 116,4 & 10,6 & 73,6 & 100,2 & 94,1 & 152,8 & 310,5 & 274,6 & 1819,6 \\
\hline 1985 & 594,9 & 483,2 & 459,7 & 528,6 & 102,1 & 31,1 & 7,2 & 59,1 & 153,1 & 69,0 & 312,8 & 233,2 & 3034,0 \\
\hline 1986 & 135,8 & 586,0 & 473,9 & 279,9 & 105,4 & 68,6 & 108,5 & 127,5 & 234,2 & 144,7 & 179,9 & 732,1 & 3176,5 \\
\hline 1987 & 343,4 & 132,5 & 103,4 & 389,3 & 234,8 & 143,5 & * & 31,6 & 122,7 & 260,9 & 200,2 & 258,5 & 2220,8 \\
\hline 1988 & 273,1 & 643,2 & 254,6 & 282,5 & 186,2 & 109,2 & 39,4 & 7,5 & 233,0 & 205,3 & 131,2 & 310,4 & 2675,6 \\
\hline 1989 & 249,4 & 218,3 & 434,3 & 135,4 & 86,6 & 269,2 & 169,4 & 69,6 & 252,7 & 176,3 & 247,1 & 186,8 & 2495,1 \\
\hline 1990 & 97,2 & 80,1 & 280,4 & 309,7 & 111,8 & 41,8 & 81,9 & 84,7 & 125,6 & 381,2 & 166,8 & 182,7 & 1943,9 \\
\hline
\end{tabular}


Tabela 2. Total de chuva mensal $(\mathrm{mm})$ no período de 1935 - 2001.Instituto Agronômico - Seção de Climatologia Agrícola da Estação Experimental de Ubatuba

\begin{tabular}{llllllllllllll}
\hline Ano & jan & fev & mar & abr & mai & jun & jul & ago & set & out & nov & dez & Anual \\
\hline 1991 & 285,7 & 291,0 & 517,2 & 145,0 & 141,7 & 38,6 & 96,9 & 63,6 & 166,5 & 148,7 & 145,1 & 126,9 & 2166,9 \\
1992 & 612,7 & 107,8 & 104,5 & 123,1 & 367,6 & 6,6 & 150,4 & 65,6 & 305,2 & 304,1 & 474,4 & 231,6 & 2853,6 \\
1993 & 262,9 & 359,8 & 479,2 & 152,2 & 90,7 & 141,4 & 47,8 & 18,9 & 218,0 & 110,8 & 112,8 & 255,3 & 2249,8 \\
1994 & 311,5 & 311,3 & 458,8 & 444,0 & 87,3 & 166,3 & 70,8 & 57,2 & 224,6 & 352,4 & 195,2 & 157,1 & 2836,5 \\
1995 & 346,9 & 407,2 & 381,2 & 116,2 & 115,8 & 142,1 & 99,5 & 161,8 & 184,8 & 336,6 & 277,9 & 287,2 & 2857,2 \\
1996 & 392,8 & 898,6 & 471,4 & 152,4 & 79,5 & 89,6 & 73,1 & 69,4 & 277,6 & 217,1 & 267,9 & 192,2 & 3181,6 \\
1997 & 354,3 & 61,0 & 81,8 & 114,8 & 148,0 & 79,1 & 35,2 & 80,7 & 245,8 & 284,9 & 497,4 & 242,7 & 2225,7 \\
1998 & 344,8 & 538,8 & 445,4 & 159,4 & 159,9 & 22,4 & 29,0 & 117,7 & 266,5 & 396,6 & 232,7 & 193,9 & 2907,1 \\
1999 & 207,3 & 295,6 & 227,4 & 250,4 & 58,1 & 135,3 & 126,1 & 32,8 & 218,0 & 311,9 & 126,0 & 348,3 & 2337,2 \\
2000 & 367,0 & 261,7 & 280,5 & 72,2 & 22,4 & 41,7 & 78,3 & 70,0 & 169,4 & 157,0 & 275,1 & 340,1 & 2135,4 \\
2001 & 253,1 & 162,9 & 193,3 & 97,4 & 163,8 & 72,6 & 113,4 & $*$ & $*$ & $*$ & $*$ & $*$ & 1056,5 \\
\hline
\end{tabular}

\subsubsection{Evapotranspiração (ETP)}

A Evapotranspiração Potencial (ETP) da área foi calculada pelo método de Thornthwaite \& Matter (1955).

Os dados de temperatura média mensal (T) do ar e de chuva total mensal $(P)$ foram obtidos junto à Seção de Climatologia Agrícola do Instituto Agronômico de Campinas. 
Tabela 3. Temperatura Media [Max+Min]/2 ( $\left.{ }^{\circ} \mathrm{C}\right)$ no período de $1935-2001$. Instituto Agronômico - Seção de Climatologia Agrícola da Estação Experimental de Ubatuba

\begin{tabular}{|c|c|c|c|c|c|c|c|c|c|c|c|c|c|}
\hline Ano & jan & fev & mar & abr & mai & jun & jul & ago & set & out & nov & dez & Anual \\
\hline 1955 & 24,3 & 25,0 & 23,9 & 22,2 & 19,4 & 18,4 & 18,6 & 18,2 & 20,0 & 19,9 & 22,0 & 24,0 & 21,3 \\
\hline 1956 & 26,5 & 24,8 & 24,6 & 22,4 & 19,1 & 18,0 & 17,7 & 17,2 & 20,5 & 20,2 & 20,9 & 22,7 & 21,2 \\
\hline 1957 & 25,0 & 25,5 & 25,9 & 22,9 & 19,9 & 17,8 & 18,0 & 18,6 & 19,7 & 21,9 & 21,5 & 24,1 & 21,7 \\
\hline 1958 & 25,0 & 25,4 & 23,7 & 21,9 & 19,9 & 18,6 & 18,9 & 20,0 & 19,7 & 21,4 & 23,0 & 24,7 & 21,8 \\
\hline 1959 & 24,5 & 25,8 & 23,8 & 24,7 & 21,1 & 18,2 & 18,7 & 18,6 & 20,4 & 21,4 & 21,9 & 23,4 & 21,9 \\
\hline 1960 & 23,6 & 23,6 & 23,1 & 21,4 & 18,5 & 18,1 & 16,9 & 19,0 & 19,4 & 22,3 & 22,1 & 23,1 & 20,9 \\
\hline 1961 & 24,4 & 25,1 & 23,6 & 22,8 & 19,7 & 19,6 & 18,4 & 19,1 & 21,4 & 22,4 & 23,2 & 23,8 & 21,9 \\
\hline 1962 & 23,5 & 24,6 & 24,2 & 21,6 & 18,9 & 16,0 & 16,8 & 17,7 & 19,9 & 20,5 & 22,1 & 23,0 & 20,7 \\
\hline 1963 & 25,2 & 25,0 & 25,3 & 21,8 & 18,6 & 18,2 & 18,6 & 19,1 & 21,4 & 22,4 & 23,4 & 23,6 & 21,9 \\
\hline 1964 & 23,5 & 24,2 & 23,3 & 22,3 & 19,8 & 17,9 & 16,5 & 18,5 & 19,6 & 20,3 & 21,5 & 23,5 & 20,9 \\
\hline 1965 & 23,7 & 25,0 & 23,4 & 22,8 & 20,2 & 20,0 & 18,5 & 19,7 & 21,1 & 21,6 & 22,5 & 25,3 & 22,0 \\
\hline 1966 & 25,5 & 26,5 & 24,5 & 22,5 & 20,3 & 19,5 & 19,3 & 18,6 & 18,6 & 21,0 & 22,1 & 24,7 & 21,9 \\
\hline 1967 & 24,5 & 25,1 & 24,1 & 22,3 & 20,8 & 19,3 & 18,0 & 19,4 & 19,8 & 22,2 & 21,6 & 21,8 & 21,6 \\
\hline 1968 & 24,1 & 22,8 & 23,6 & 20,1 & 17,2 & 17,5 & 17,2 & 17,4 & 18,2 & 19,9 & 21,7 & 23,9 & 20,3 \\
\hline 1969 & 25,2 & 25,9 & 24,9 & 21,8 & 20,5 & 19,2 & 18,0 & 19,0 & 20,3 & 20,3 & 23,2 & 21,9 & 21,7 \\
\hline 1970 & 23,7 & 24,9 & 24,7 & 22,0 & 21,4 & 20,1 & 18,0 & 18,0 & 19,3 & 19,2 & 19,3 & 22,2 & 21,0 \\
\hline 1971 & 24,1 & 25,8 & 25,1 & 22,4 & 20,2 & 18,4 & 18,4 & 19,2 & 19,1 & 19,8 & 21,1 & 23,4 & 21,4 \\
\hline 1972 & 25,3 & 25,0 & 25,0 & 21,7 & 21,2 & 20,7 & 18,8 & 19,5 & 20,4 & 21,3 & 22,6 & 24,2 & 22,1 \\
\hline 1973 & 26,4 & 26,5 & 24,4 & 24,8 & 21,0 & 20,3 & 19,9 & 18,5 & 19,4 & 20,2 & 20,9 & 24,2 & 22,2 \\
\hline 1974 & 24,7 & 25,0 & 24,6 & 22,0 & 20,4 & 18,5 & 18,5 & 18,8 & 19,8 & 20,2 & 21,8 & 22,4 & 21,4 \\
\hline 1975 & 23,4 & 24,9 & 24,4 & 20,9 & 19,3 & 18,1 & 16,8 & 20,0 & 19,8 & 21,1 & 22,6 & 24,8 & 21,3 \\
\hline 1976 & 26,5 & 24,8 & 24,8 & 22,6 & 20,6 & 18,9 & 18,0 & 19,1 & 19,7 & 20,5 & 22,8 & 24,4 & 21,9 \\
\hline 1977 & 25,4 & 26,3 & 25,5 & 23,1 & 20,8 & 20,3 & 21,1 & 21,0 & 20,8 & 22,0 & 23,3 & 23,1 & 22,7 \\
\hline 1978 & 25,4 & 24,9 & 24,9 & 21,6 & 20,0 & 18,3 & 19,8 & 19,0 & 20,5 & 21,8 & 23,0 & 23,9 & 21,9 \\
\hline 1979 & 22,7 & 24,9 & 23,4 & 22,4 & 21,0 & 18,6 & 17,8 & 20,5 & 20,1 & 22,4 & 22,3 & 24,4 & 21,7 \\
\hline 1980 & 24,6 & 25,7 & 26,3 & 23,5 & 21,9 & 19,4 & 19,7 & 19,9 & 19,3 & 21,8 & 22,7 & 25,8 & 22,5 \\
\hline 1981 & 25,3 & 26,0 & 24,7 & 22,5 & 21,4 & 19,0 & 17,8 & 19,4 & 21,1 & 20,9 & 23,5 & 24,0 & 22,1 \\
\hline 1982 & 23,4 & 25,7 & 24,1 & 21,7 & 19,4 & 20,4 & 19,5 & 20,1 & 20,1 & 21,9 & 24,5 & 24,0 & 22,0 \\
\hline
\end{tabular}


Tabela 3. Temperatura Media [Max+Min]/2 ( $\left.{ }^{\circ} \mathrm{C}\right)$ no período de $1935-2001$. Instituto Agronômico - Seção de Climatologia Agrícola da Estação Experimental de Ubatuba

\begin{tabular}{rlllllllllllll}
\hline Ano & jan & fev & mar & abr & mai & jun & jul & ago & set & out & nov & dez & Anual \\
\hline 1983 & 26,0 & 26,6 & 24,9 & 23,2 & 21,9 & 19,6 & 19,4 & 18,8 & 19,3 & 21,5 & 24,0 & 25,0 & 22,5 \\
1984 & 27,2 & 27,2 & 25,4 & 22,6 & 22,8 & 20,7 & 19,8 & 18,8 & 19,1 & 22,0 & 22,9 & 23,4 & 22,6 \\
1985 & 23,9 & 26,3 & 25,7 & 24,3 & 20,6 & 18,6 & 17,9 & 20,0 & 19,7 & 21,5 & 23,0 & 23,9 & 22,1 \\
1986 & 26,2 & 26,7 & 26,0 & 24,6 & 22,6 & 19,7 & 18,4 & 20,2 & 20,1 & 21,2 & 23,9 & 25,2 & 22,9 \\
1987 & 26,8 & 26,3 & 24,2 & 24,5 & 21,1 & 18,8 & 0,0 & 19,3 & 18,5 & 21,4 & 23,1 & 24,8 & 20,7 \\
1988 & 27,5 & 25,2 & 25,3 & 23,4 & 21,2 & 18,4 & 16,8 & 19,4 & 20,4 & 21,0 & 22,3 & 24,5 & 22,1 \\
1989 & 25,9 & 26,6 & 25,5 & 23,9 & 20,5 & 19,3 & 18,1 & 19,6 & 20,5 & 20,3 & 23,0 & 23,7 & 22,2 \\
1990 & 27,0 & 26,0 & 26,2 & 25,3 & 20,5 & 19,2 & 18,1 & 18,4 & 19,3 & 22,6 & 25,0 & 24,6 & 22,7 \\
1991 & 24,7 & 25,3 & 25,0 & 23,6 & 21,3 & 20,5 & 19,0 & 19,5 & 19,0 & 22,2 & 23,3 & 26,1 & 22,4 \\
1992 & 25,3 & 25,7 & 25,3 & 23,6 & 22,7 & 21,4 & 19,3 & 18,9 & 20,6 & 22,5 & 22,8 & 23,6 & 22,6 \\
1993 & 26,6 & 26,0 & 25,9 & 24,5 & 21,6 & 19,7 & 20,2 & 18,7 & 20,4 & 23,0 & 24,5 & 25,1 & 23,0 \\
1994 & 24,9 & 28,2 & 25,0 & 23,5 & 22,6 & 19,5 & 19,5 & 18,8 & 20,4 & 23,0 & 24,1 & 25,7 & 22,9 \\
1995 & 27,0 & 26,3 & 25,2 & 23,4 & 21,2 & 19,8 & 20,7 & 21,2 & 20,8 & 21,3 & 23,3 & 24,8 & 22,9 \\
1996 & 27,2 & 26,8 & 25,7 & 23,9 & 20,5 & 19,5 & 17,7 & 18,4 & 20,1 & 22,1 & 22,6 & 25,5 & 22,5 \\
1997 & 25,8 & 26,1 & 24,1 & 23,1 & 20,7 & 20,3 & 19,9 & 19,7 & 21,2 & 22,6 & 24,6 & 26,0 & 22,8 \\
1998 & 27,1 & 27,5 & 26,5 & 24,4 & 21,1 & 19,1 & 19,5 & 21,6 & 21,6 & 21,3 & 21,9 & 24,4 & 23,0 \\
1999 & 26,7 & 26,8 & 25,7 & 23,0 & 20,3 & 19,4 & 19,1 & 18,9 & 20,9 & 20,6 & 21,3 & 24,3 & 22,3 \\
2000 & 25,6 & 25,4 & 24,5 & 22,9 & 21,1 & 20,1 & 17,6 & 19,3 & 20,5 & 23,4 & 23,4 & 25,2 & 22,4 \\
2001 & 26,7 & 27,8 & 25,9 & 25,1 & 21,4 & 20,6 & 19,6 & $*$ & $*$ & $*$ & $*$ & $*$ & 23,9 \\
\hline
\end{tabular}

Os cálculos de evapotranspiração potencial mensal foram realizados para um período de 10 anos (1972 a 1981), utilizando as planilhas EXCEL disponibilizadas pelo núcleo de monitoramento agroclimático, organizado por Sentelhas et al. (1999) ${ }^{3}$.

O posto meteorológico do DAEE mais próximo encontra-se no município de Juquiá, denominado como Posto Prefixo F4-020 HM e está localizado nas coordenadas $24^{\circ} 20^{\prime} \mathrm{S}$ e $47^{\circ} 37^{\prime} \mathrm{W}$, com altitude $67 \mathrm{~m}$.

\footnotetext{
${ }^{3}$ Disponível na internet no endereço: http://www.lce.esalq.usp.br/nurma.html
} 
Para aprimoramento dos estudos, foi feita a comparação do posto de Juquiá (tanque de classe A) com os dados calculados para ETP em Ubatuba, pelo método Thornthwaite \& Matter (1955), apresentados na Tabela 04, e verificou-se a consistências dos dados, conforme pode ser visualizado na Figura 16.

Tabela 4. ETP calculado pelo método Thornthwaite \& Matter(1955) na Bacia do Rio Grande e dados do Tanque Classe A da Bacia de Juquiá

\begin{tabular}{ccc}
\hline & $\begin{array}{c}\text { ETP } \\
\text { Thornthwaite } \\
\text { Rio Grande }\end{array}$ & $\begin{array}{c}\text { ETP } \\
\text { Tanque Classe A } \\
\text { Juquiá }\end{array}$ \\
\hline ago & 59,5 & 53,0 \\
set & 65,1 & 60,0 \\
out & 82,2 & 81,0 \\
nov & 96,8 & 98,0 \\
dez & 120,3 & 114,0 \\
jan & 126,9 & 112,0 \\
fev & 119,7 & 110,0 \\
mar & 121,3 & 97,0 \\
abr & 85,9 & 66,0 \\
mai & 68,5 & 53,0 \\
jun & 52,1 & 45,0 \\
jul & 51,3 & 47,0 \\
\hline
\end{tabular}




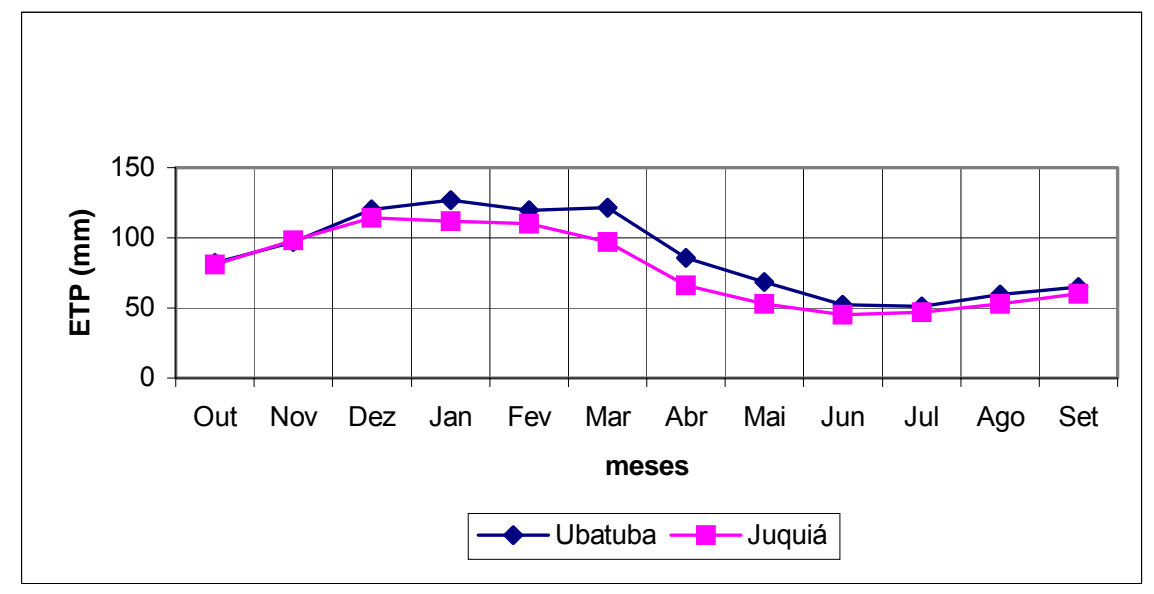

Figura 16 - Comparação entre a ETP mensal $(\mathrm{mm})$ calculada em Ubatuba pelo método Thornthwaite \& Matter (1955) com o Tanque Classe A de Juquiá, para o período de 1972 a 1981

\subsubsection{Modelo SMAP}

O modelo SMAP (Soil Moisture Accounting Procedure) é um modelo de simulação hidrológica do tipo transformação chuva-vazão desenvolvido por Lopes et al (1981), que apresenta uma estrutura simples, para séries contínuas, e utiliza para a separação do escoamento superficial (direto) os conceitos do Soil Conservation Service (SCS).

Para a simulação hidrológica de transformação de chuva-vazão para a Bacia do Rio Grande de Ubatuba foi utilizada a versão mensal do modelo. Também foi usado o programa de computador, desenvolvido por Lopes ${ }^{4}$ que foi gentilmente cedido pelo autor. Na versão mensal do modelo apresenta dois reservatórios matemáticos:

Reservatório da água no solo (Rsolo);

Reservatório de água subterrânea (Rsub)

${ }^{4}$ Contato com o autor João E.G. Lopes : jelopes@dghnet.com.br 
Na Figura 17 pode-se observar que o modelo apresenta quatro funções de transferência da água entre os reservatórios e para fora dos mesmos. Estas transferências são:

T1 - Escoamento Superficial (Es)

T2 - Evapotranspiração Real (Er)

T3 - Recarga da água subterrânea (Rec)

T4 - Escoamento base (Eb)

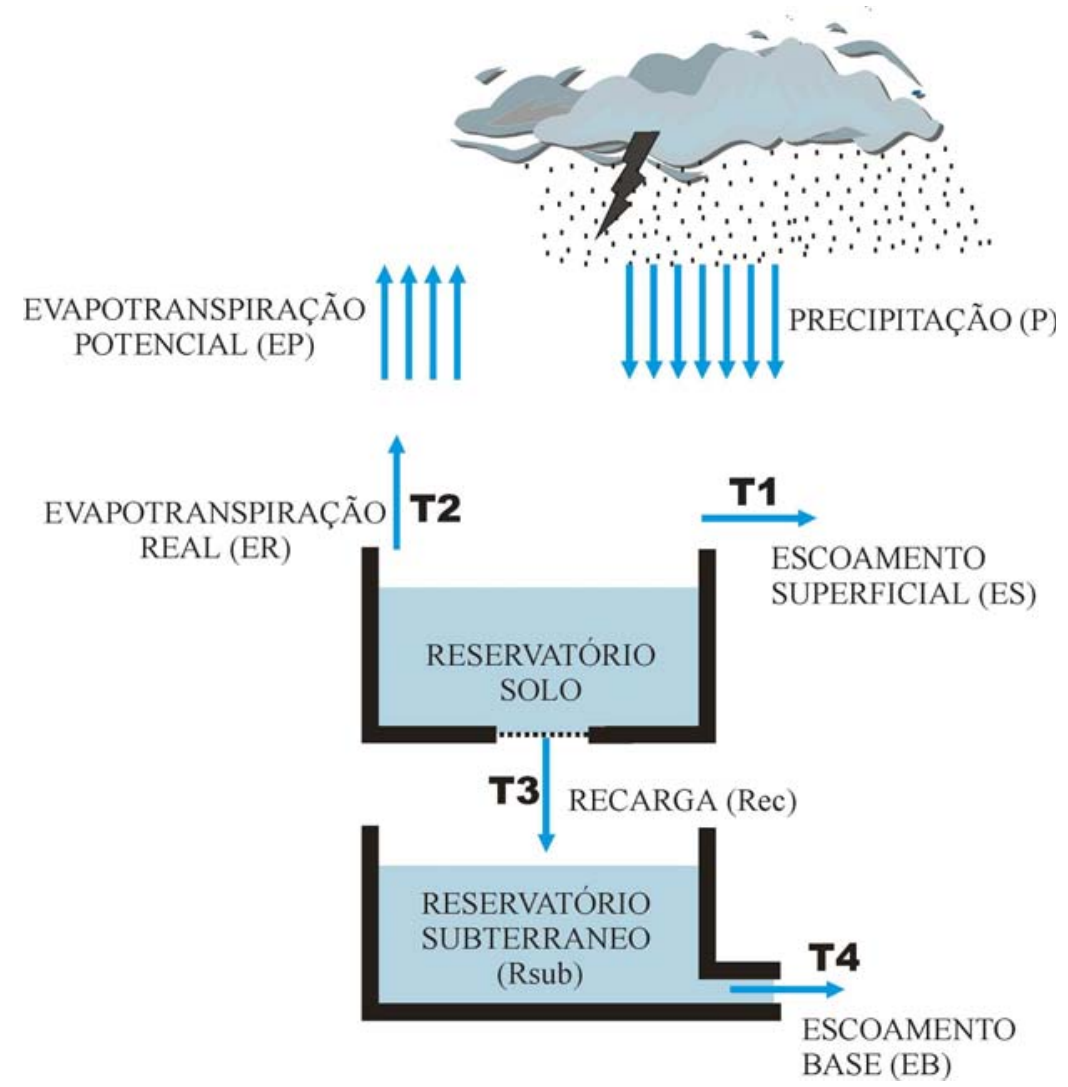

Figura 17 - Ilustração da estrutura do Modelo SMAP na versão mensal

Para o cálculo destas transferências surgem os quatro parâmetros do modelo SMAP, que são: 
Str = Capacidade de saturação do solo $(\mathrm{mm})$

Pes $=$ Parâmetro de escoamento superficial (admensional)

Crec $=$ Coeficiente de recarga (admensional)

$\mathrm{Kk}=$ constante de recessão do escoamento base (mês $\left.{ }^{-1}\right)$

A partir desses parâmetros, têm-se as equações para o cálculo das variáveis do modelo.

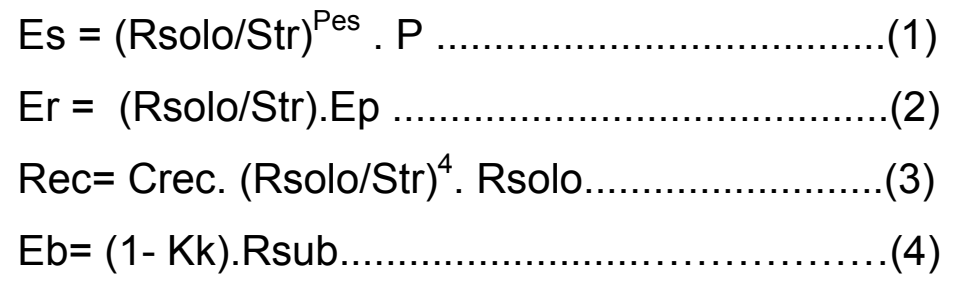

As variáveis de estado são atualizadas a cada mês da seguinte forma: para o reservatório do solo (zona aerada)

Rsolo $(t+1)=R$ solo $(t)+P-E s-E r-\operatorname{Rec} \ldots .(5)$

onde:

$$
\begin{aligned}
& P=\text { chuva } \\
& E s=\text { escoamento superficial } \\
& E r=\text { evapotranspiração real } \\
& \operatorname{Rec}=\text { recarga subterrânea }
\end{aligned}
$$

para o reservatório subterrâneo (zona saturada)

$\operatorname{Rsub}(t+1)=\operatorname{Rsub}(t)+\operatorname{Rec}-E b$

onde: 
$\mathrm{Eb}=$ escoamento básico
$\operatorname{Rec}=$ recarga subterrânea

e finalmente a vazão é dada por

$Q=(E s+E b) \cdot A d / 2630$

$\mathrm{Q}=\operatorname{vazão}\left(\mathrm{m}^{3} / \mathrm{s}\right)$

Es = escoamento superficial $\left(\mathrm{m}^{3} / \mathrm{s}\right)$

$\mathrm{Eb}=$ vazão básica $\left(\mathrm{m}^{3} / \mathrm{s}\right)$

Ad = área de drenagem $\left(\mathrm{km}^{2}\right)$

O modelo inicia-se com o cálculo da capacidade do reservatório de água no solo no mês 1 - Rsolo (1) e o cálculo da recarga subterrânea no mês 1 Rsub (1):

a) Rsolo (1) = Tuin . Str

onde:

Tuin = teor de umidade inicial (ad.)

Str = capacidade de saturação do solo $(\mathrm{mm})$

b) Rsub (1) $=($ Ebin / (1-Kk)) / Ad . 2630

onde:

$$
\begin{aligned}
& \text { Ebin = vazão básica inicial }\left(\mathrm{m}^{3} / \mathrm{s}\right) \\
& \mathrm{Kk}=\text { constante de recessão do escoamento base }\left(\mathrm{m}^{-1}\right) \\
& \mathrm{Ad}=\text { área de drenagem }\left(\mathrm{km}^{2}\right)
\end{aligned}
$$

Recomenda-se que o mês 1 seja o primeiro mês do ano hídrico e necessita dos seguintes dados de entrada: 
a) a série mensal de chuva;

b) as médias mensais multianuais de evaporação potencial (tanque Classe $A$ ); e no caso do período de calibração,

c) a série mensal de vazões.

Para o programa de calibração são necessários de 2 a 9 anos de dados de vazão media mensal. E existem dois coeficientes de ajuste, da chuva média da bacia (Pcof) e ajuste da evaporação média da bacia (Ecof), que devem ser calculados em função da distribuição espacial dos postos.

A seguir, no Quadro 1, apresenta-se a estrutura dos dados de entrada para o período de calibração e validação, e no Quadro 2, a estrutura de entrada de dados para a geração da série histórica. 


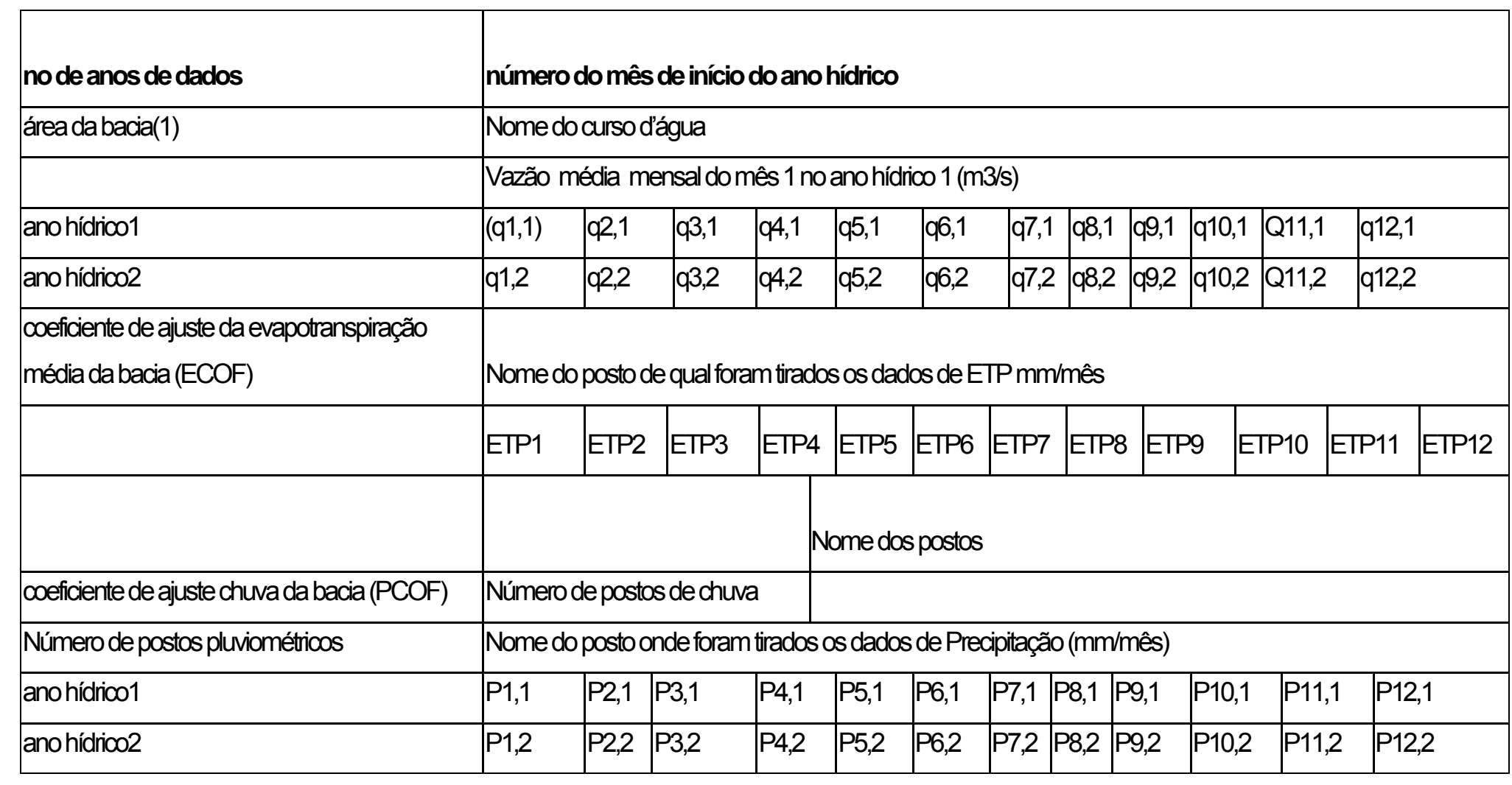

Quadro 1 - Estrutura de entrada de dados do Modelo SMAP na versão mensal (Para calibração e validação do modelo) 


\begin{tabular}{|c|c|}
\hline \multicolumn{2}{|c|}{ Nome do Rio - Geração de Série Histórica no Posto (nome do posto) } \\
\hline \multicolumn{2}{|r|}{ Nome do Posto de chuva e localização } \\
\hline & Nome do Posto de evaporação \\
\hline Ano inicial & ano inicial da simulação \\
\hline $\mathrm{N}^{\circ}$ de anos & número de anos para simulação \\
\hline Ad & área de drenagem em km2 \\
\hline$N^{0}$ de posto & número de postos de chuva (até 9 postos) \\
\hline Pcoef & coeficiente de ajuste de chuva media na bacia \\
\hline Kk & constante de recessão do escoamento básico (em meses) \\
\hline Tuin & inicialização do reservatório do solo (\%) \\
\hline Ebin & vazão básica inicial (em m3/s) \\
\hline Str & capacidade de saturação do reservatório do solo (em mm) \\
\hline Pes & parâmetro de escoamento superficial \\
\hline Crec & parâmetro de recarga subterrânea (\%) \\
\hline mês1 mês2 mês3............m12 & seqüência de meses no ano hidrológico utilizado \\
\hline ETP1 ETP2 ETP3........ ETP12 & ETP (em mm/mes) \\
\hline $\mathrm{N}^{\circ}$ de posto & Nome do posto de chuva \\
\hline $\begin{array}{l}\text { ano hídrico } 1 \\
\text { ano hídrico } 2 \\
\text { ano hídrico } 3\end{array}$ & 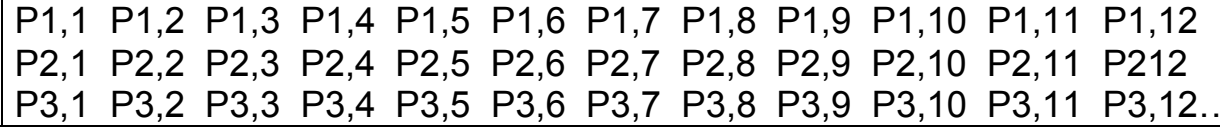 \\
\hline
\end{tabular}

Quadro 2 - Estrutura de entrada de dados do Modelo SMAP na versão mensal (Para geração da série histórica de vazão) 
A otimização para estimativa de parâmetros, uma das partes fundamentais é o estabelecimento da função objetivo. Na simulação hidrológica, o produto da simulação é um hidrograma calculado pelo modelo que é comparado com aquele observado. O objetivo é aproximar o máximo possível os dois hidrogramas. A função objetiva busca medir a discrepância entre estes valores para que possa ser minimizada .

Para a calibração dos parâmetros do modelo na versão mensal, o SMAP utiliza a soma dos desvios relativos quadráticos, como função objetivo (f.o.).

$$
\begin{aligned}
& \text { f.o. }=\sum_{\mathrm{i}=1}^{n}\left[(\operatorname{Qobs}(\mathrm{i})-\text { Qcalc }(\mathrm{i}) / \operatorname{Qobs}(\mathrm{i})]^{2}\right. \\
& \text { onde: Qobs = vazão observada } \\
& \text { Qcalc= vazão calculada }
\end{aligned}
$$

Além do valor da função objetivo, devem ser observados dois outros indicadores da calibração:

a) o armazenamento do período (balanço) deve ser próximo de zero. Isso indica que não está se retendo ou liberando água do reservatório do solo de forma tendenciosa. A variação do reservatório deve ser cíclica, acompanhando a sazonalidade da região.

b) a recarga e o escoamento básico devem ser aproximadamente iguais. Diferença entre recarga e escoamento básico indica problemas com parâmetros "Crec" (coeficiente de recarga) e "Kkt" (constante de recessão escoamento básico). 


\section{RESULTADOS}

\subsection{Calibração dos parâmetros do modelo SMAP para a bacia do Rio Grande de Ubatuba}

Para a calibração das estimativas de parâmetros da bacia do Rio Grande de Ubatuba pelo modelo SMAP, utilizou-se a série de dois anos de vazão, iniciando no mês de agosto de 1972 e terminando em julho de 1974. Esse período foi escolhido pelas seguintes razões: o programa de computador utilizado necessita de no mínimo dois anos de dados e o ano hídrico foi determinado como sendo de agosto a julho.

A calibração seguiu os seguintes passos:

a) preparo do arquivo de entrada, conforme mostra o Quadro 3.

\begin{tabular}{|l|l|l|l|l|l|l|l|l|l|l|l|l|}
\hline $\mathbf{2}$ & $\mathbf{8}$ \\
\hline 64 & \multicolumn{10}{|l|}{ Rio Grande de Ubatuba - calibração } \\
\hline $72-73$ & 2.53 & 4.16 & 5.61 & 5.19 & 4.41 & 10.20 & 8.44 & 5.13 & 5.03 & 6.92 & 2.84 & 4.66 \\
\hline $73-74$ & 2.37 & 3.82 & 4.15 & 5.51 & 6.79 & 8.89 & 3.44 & 2.40 & 2.46 & 1.73 & 1.43 & 0.97 \\
\hline 1.00 & Ubatuba evapotranspiração - Thornthwaite - media de 10 anos \\
\hline & 59.5 & 65.1 & 82.2 & 96.8 & 120.3 & 126.9 & 119.7 & 121.3 & 85.9 & 68.5 & 52.1 & 51.3 \\
\hline 1.00 & 1 & 0 & 0 \\
\hline 1.00 & Ubatuba IAC (mm/mês) \\
\hline $72-73$ & 120 & 145 & 332 & 236 & 213 & 571.6 & 291.5 & 152.5 & 140.7 & 306. & 55 & 390 \\
\hline $73-74$ & 85 & 291 & 208 & 415 & 508.1 & 564.9 & 20 & 107 & 113 & 97 & 70 & 61.7 \\
\hline
\end{tabular}

Quadro 3 - Dados de entrada para a calibração do modelo SMAP - versão mensal 
b) ao abrir o programa, encontrou-se como resultado a correlação entre as vazões calculadas e observadas de 0,819. A Figura18 mostra a tela de abertura do programa. Procedeu-se à análise dos dados e posteriormente foram feitos os reajustes necessários na busca dos melhores valores para os componentes do balanço hídrico da bacia, considerando suas características físicas e biológicas.

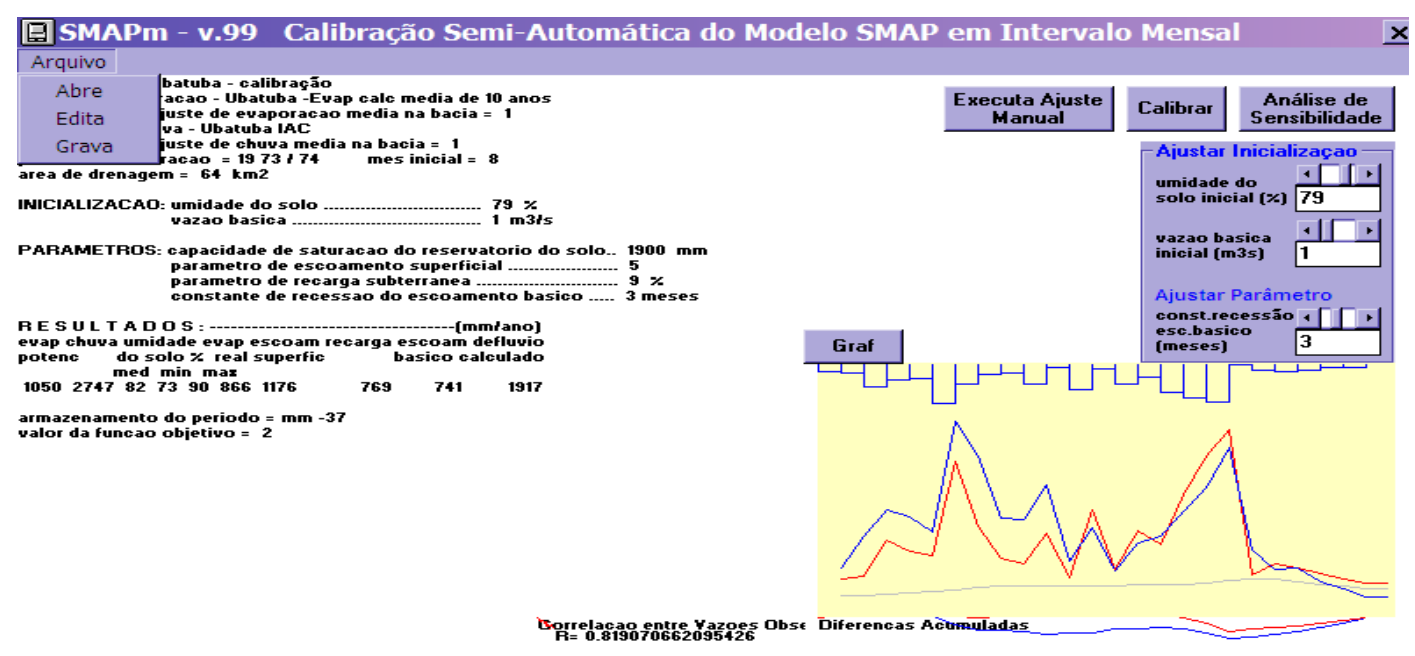

Figura 18 - Tela de abertura do programa SMAP

c) calibração automática: lançou-se mão da rotina de otimização e encontrou-se o resultado mostrado na Figura 19 que, embora tenha alcançado um bom ajuste, com pequeno aumento na correlação entre a vazão calculada e a vazão observada, ou seja de 0,853 , os valores encontrados para os escoamentos básico e superficial não correspondem à realidade física da bacia. Verificou-se valor alto para o escoamento superficial, diferentemente do que ocorre em bacia com boa cobertura florestal, e nas condições climáticas da região em que se encontra o Rio Grande de Ubatuba. Por outro lado, o valor do 
escoamento básico encontrado foi de $575 \mathrm{~mm} / a n o$, muito baixo para uma bacia com grande capacidade de infiltração da água no solo.

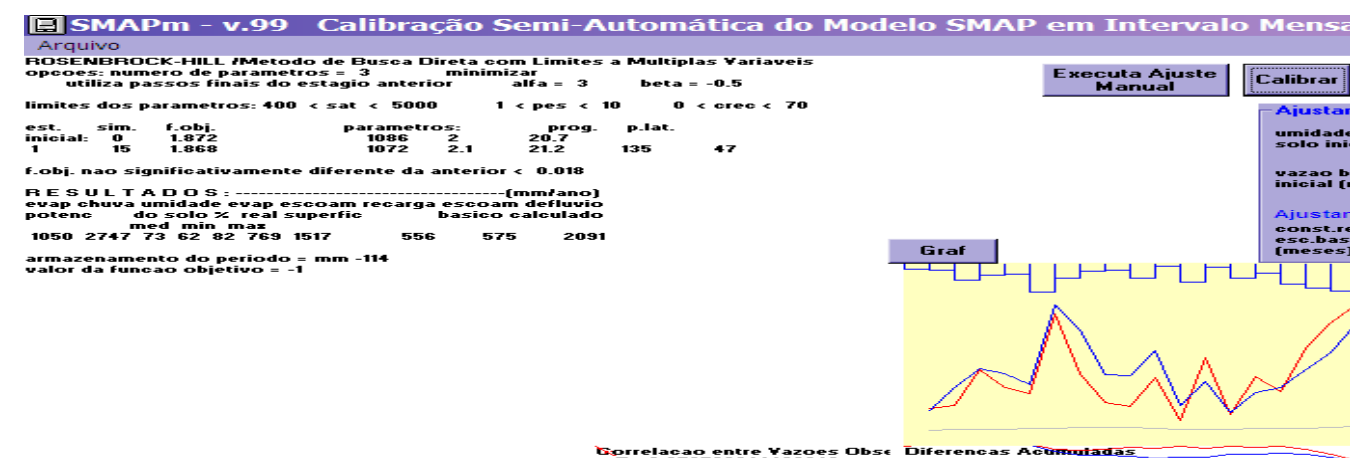

Figura 19 - Tela do programa SMAP, após calibração automática

d) buscaram-se melhores valores através do Ajuste Manual (Figura 20). Para aumentar os valores do escoamento base e recarga, o primeiro ajuste foi aumentar o parâmetro de recarga subterrânea. Os ajustes aos outros parâmetros foram feitos observando principalmente: o gráfico de correlação das vazões observadas e calculadas, os valores das variáveis dos componentes do balanço hídrico, o armazenamento de água no período, a diferença entre a recarga e o escoamento básico. 


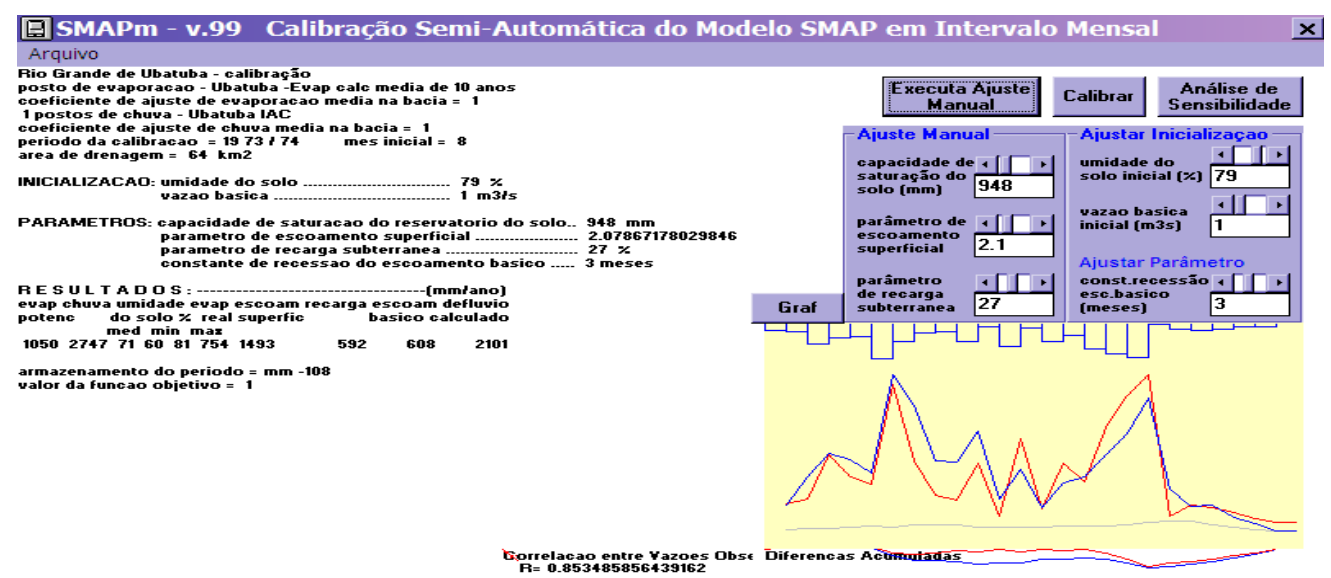

Figura 20 - Tela de resultado após os primeiros ajustes manuais

e) calibração automática: lançando-se novamente da rotina de calibração automática, encontrou-se finalmente o resultado final da calibração e os parâmetros que estão apresentados no Quadro 4. 


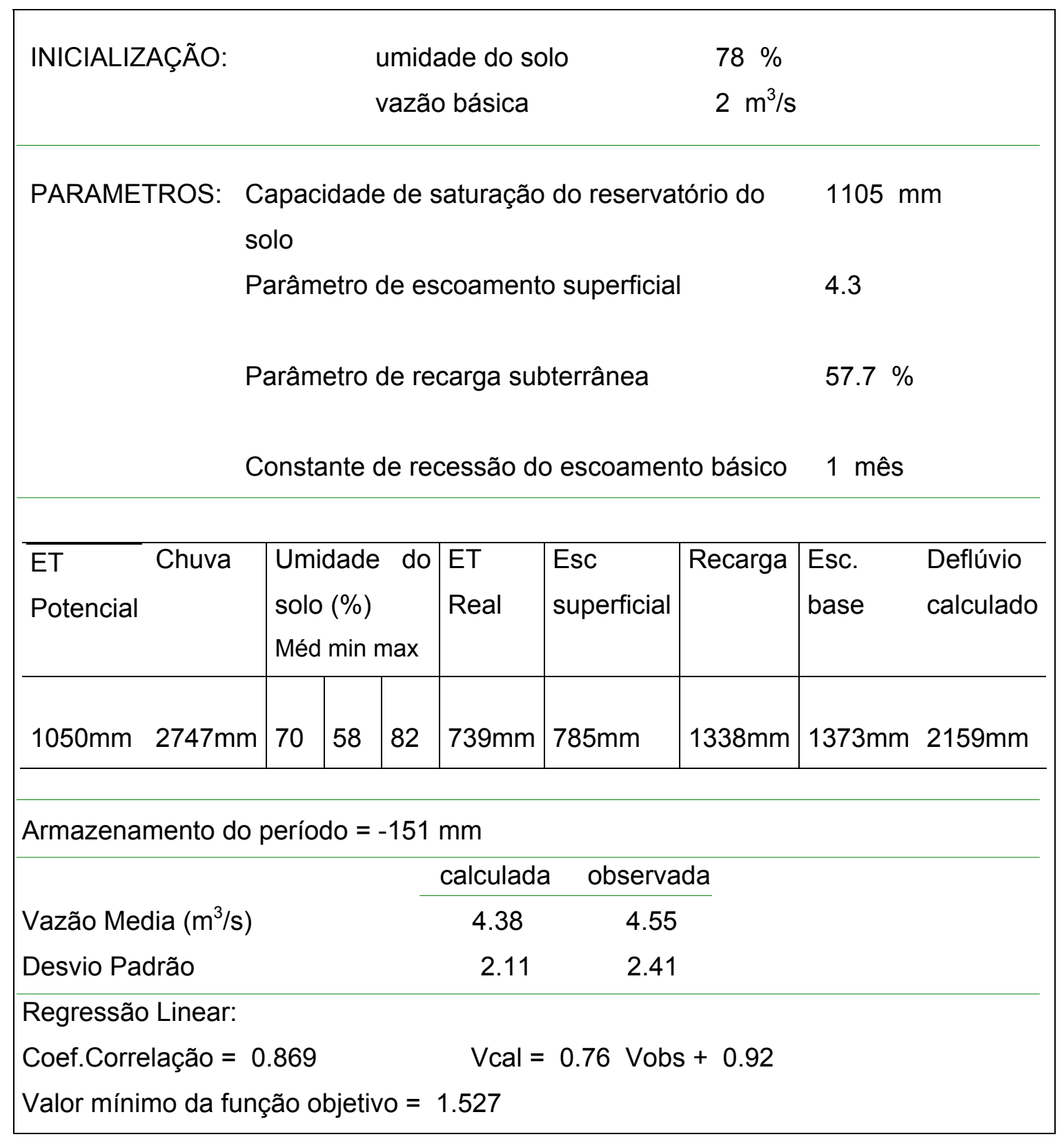

Quadro 4 - Relatório final da calibração chuva - vazão para o Rio Grande de Ubatuba 
A Figura 21 mostra as vazões observadas e as calculadas pelo modelo SMAP (fase calibração), bem como a precipitação.

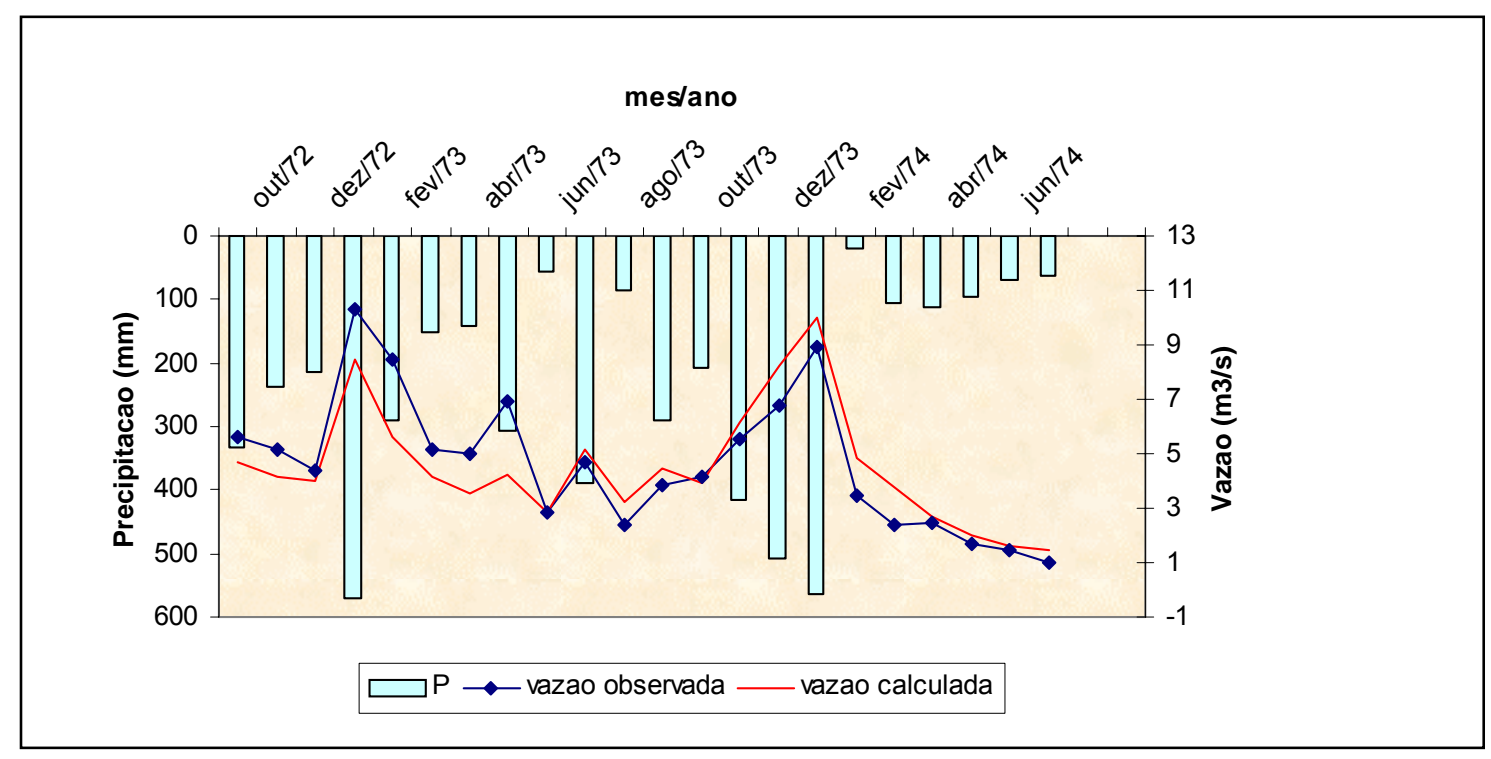

Figura 21 - Relação Chuva-Vazão calculada e vazão observada, para dois anos hídricos, na fase de calibração do Modelo SMAP

\subsection{Validação dos parâmetros da bacia do Rio Grande}

Com os parâmetros já determinados na calibração e aumentando a série de vazão média mensal para três anos, correspondente a agosto de 1971 a julho de 1975, ou seja, a quase toda série histórica disponível para o Rio Grande, foi formatado o arquivo de entrada de dados para a validação dos parâmetros, conforme apresentado no Quadro 5.

A relação obtida entre vazão observada e vazão calculada pelo modelo SMAP, utilizando-se os parâmetros calibrados, pode ser visualizada na Figura 22, enquanto o relatório final para a fase de validação encontra-se no Quadro 6. 
Observa-se que o coeficiente de correlação mudou de 0,869 ( calibração) para 0,838 (validação) e que os valores anuais de ET potencial e real, de escoamento superficial de recarga e de deflúvio calculado, não apresentaram grandes diferenças entre a fase de calibração e de validação.

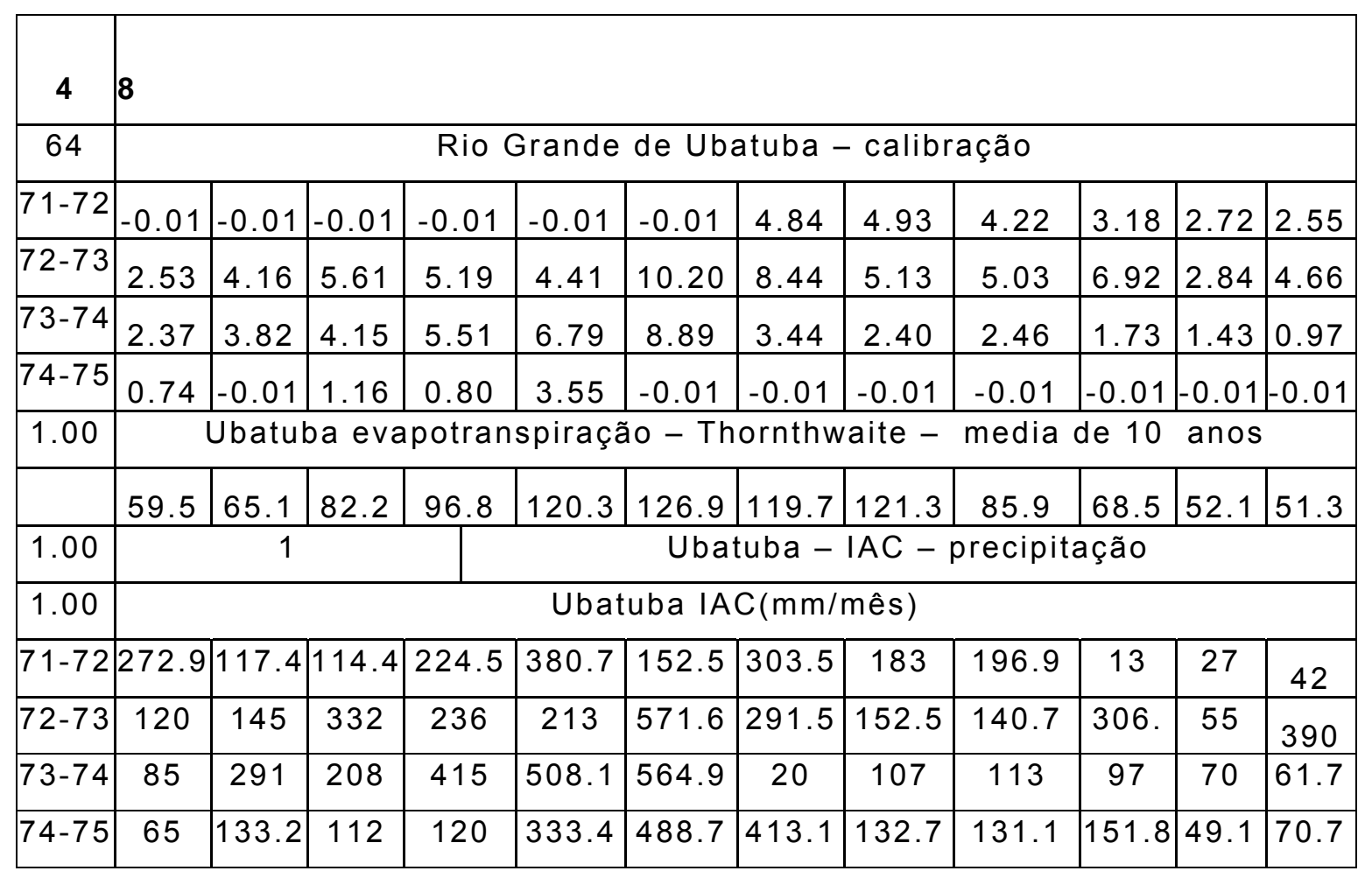

Quadro 5 - Dados de entrada para a validação do modelo SMAP - versão mensal 


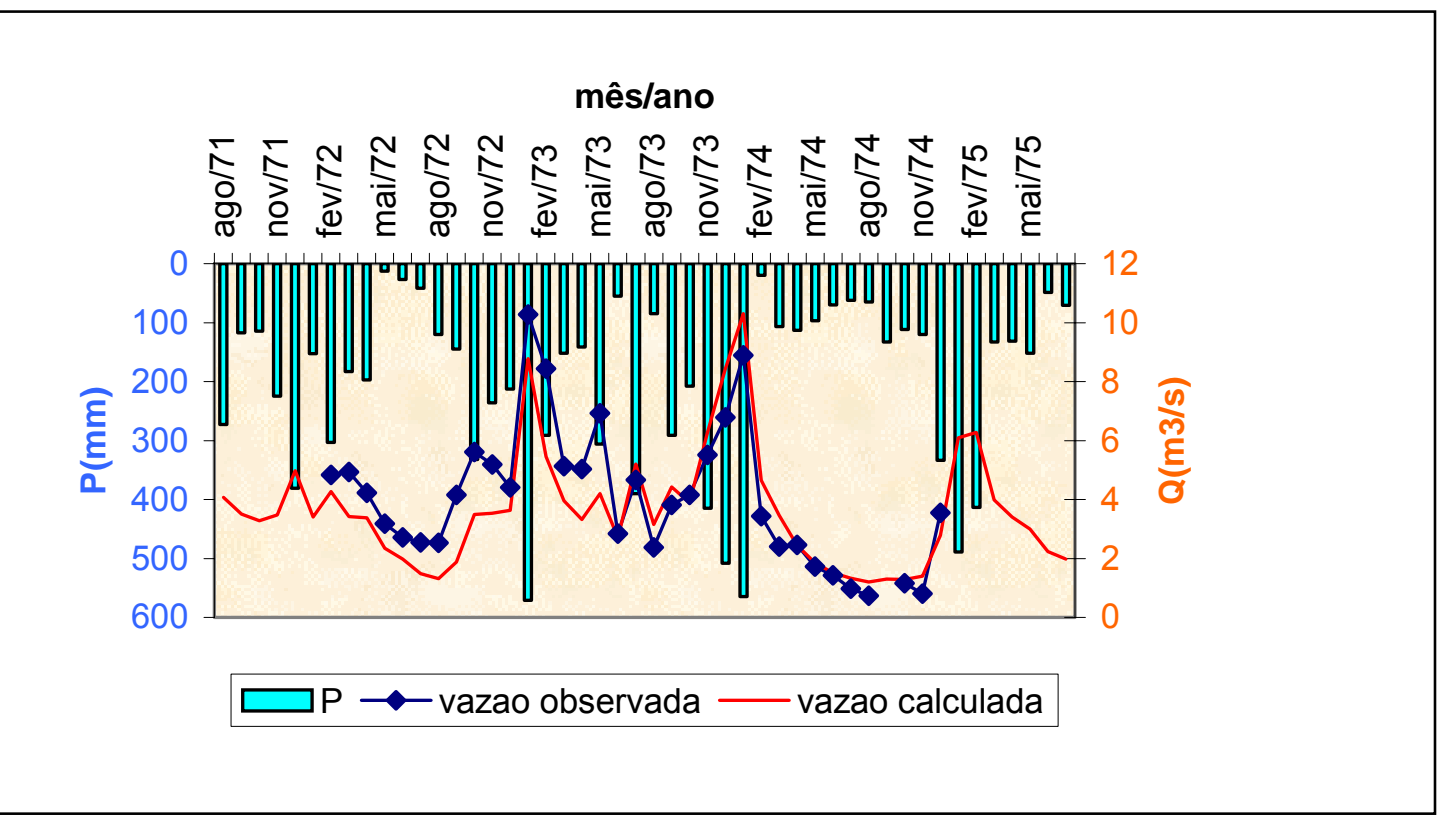

Figura 22 - Relação Chuva - Vazão calculada e observada, para os quatro anos hídricos, na fase de validação do Modelo SMAP 


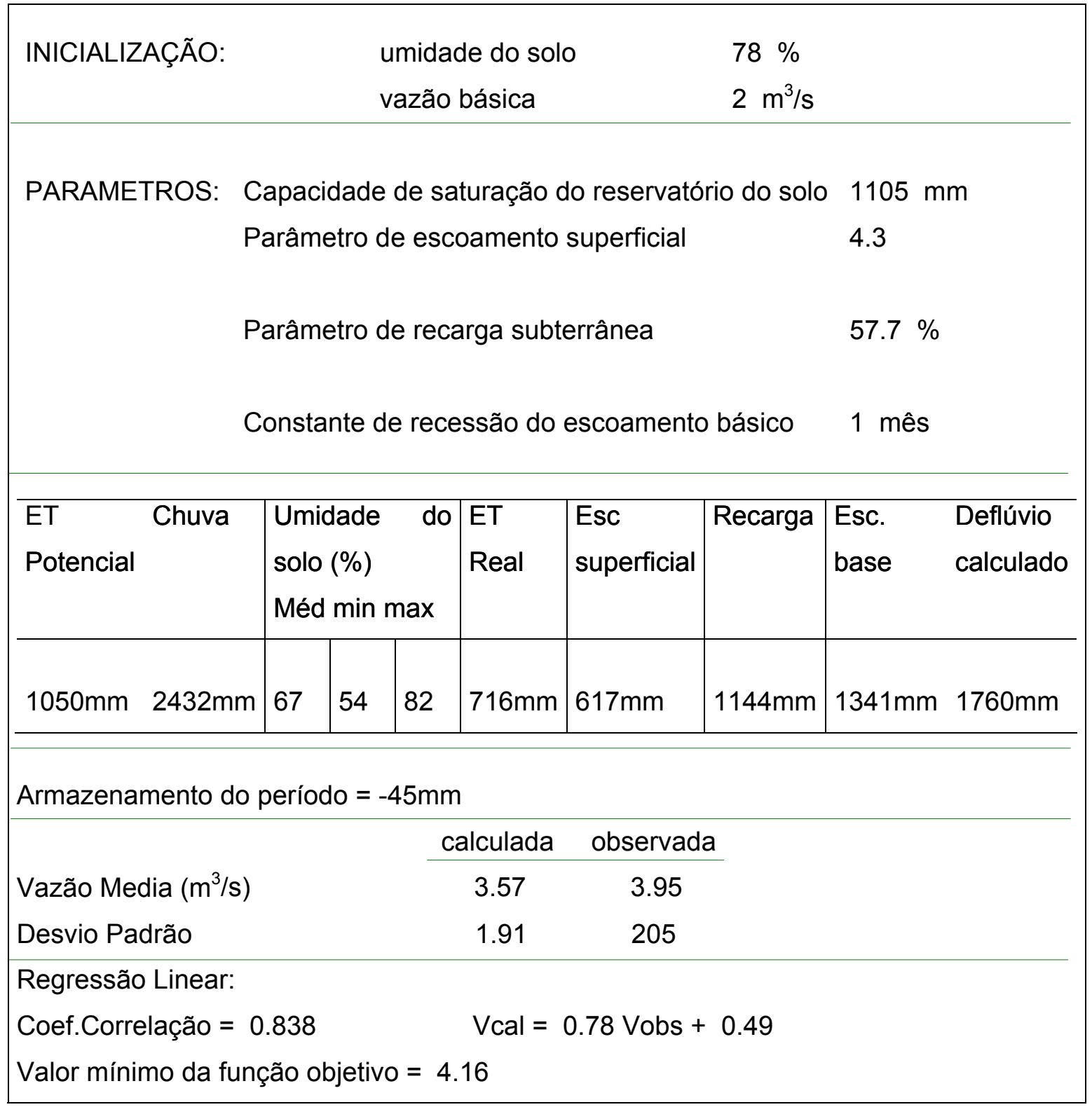

Quadro 6 - Relatório final da validação do Modelo SMAP para o Rio Grande de Ubatuba 


\subsection{Geração da série histórica}

Após as etapas de calibração e validação dos parâmetros do modelo pode-se gerar a série histórica, utilizando agora um outro programa de computador enominada SMAP G.

O arquivo de entrada deste programa incorpora os parâmetros obtidos na fase de calibração e validação e os 67anos de dados de precipitação. A estrutura do arquivo de entrada encontra-se no Quadro 7, em que se pode ver, em destaque, que a área da bacia, para gerar a nova série, é agora de $26 \mathrm{~km}^{2}$, uma vez que a área da bacia desde o ponto de captação tem $26 \mathrm{~km}^{2}$. Ressalte-se ainda que, devido ao volume de dados de precipitação , o Quadro 7 traz apenas a indicação de onde inserir aqueles dados. 
Rio Grande em Ubatuba - Geração de Série no Posto

Posto de chuva - UBATUBA LAT:23 27's LONG:45 04'w ALT:08 m INSTITUTO AGRONOMICO

Posto de evaporação - Ubatuba Calculado

35 Ano inicial da simulação (ano hidr. ago/jul)

67 Número de anos para simulação (ate' 9 anos)

26 Área de drenagem (em km2)

$1 \quad$ Numero de postos de chuva (até 9 postos)

1.00 Coeficiente de ajuste de chuva média na bacia

1. Constante de recessão do escoamento básico (em meses)

78 Inicializacão do reservatório do solo (\%)

2 Vazão básica inicial $\left(\mathrm{em} \mathrm{m}^{3} / \mathrm{s}\right)$

1105 Capacidade de saturação do reservatório do solo (em $\mathrm{mm}$ )

4.3 Parâmetro de escoamento superficial

57.7 Parâmetro de recarga subterrânea (\%)

891011121234567 seqüência de meses no ano hidrológico utilizado

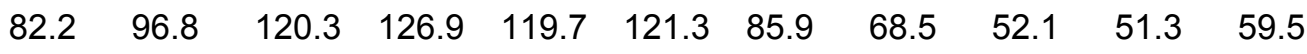

65.1 ETP( em mm/mês - ago a jul)

1.0 SECAO DE CLIMATOLOGIA AGRÍCOLA (mm/mês)

Dados anuais de precipitação ( série histórica de 1935 a 2001)

Quadro 7 - Dados de entrada para a geração da série histórica, pelo modelo SMAP G

Os resultados médios obtidos após a geração da série histórica estão apresentados no Quadro 8, e a série histórica na Tabela 5 e, por sua vez , 0 gráfico da relação chuva - vazão, para a série gerada, é mostrado na Figura 23. 


\begin{tabular}{|c|c|c|c|c|c|c|c|}
\hline $\begin{array}{c}\text { ET } \\
\text { potencial }\end{array}$ & Chuva & $\begin{array}{c}\text { ET } \\
\text { Real }\end{array}$ & $\begin{array}{c}\text { Esc. } \\
\text { superficial }\end{array}$ & Recarga & $\begin{array}{c}\text { Esc. } \\
\text { base }\end{array}$ & $\begin{array}{c}\text { Deflúvio } \\
\text { calculado }\end{array}$ & Vazão \\
\hline \multicolumn{7}{|c|}{$\mathbf{m m}$} \\
\hline $\mathbf{1 0 5 0}$ & 2652 & 722 & 785 & 1147 & 1156 & 1941 & 1.59 \\
\hline
\end{tabular}

Quadro 8 - Resultados médios anuais para a série histórica gerada

A estimativa de evapotranspiração potencial foi determinada por Arcova et al.(1998), monitorando duas microbacias durante seis anos, e foi realizada no Parque Estadual da Serra do Mar em Cunha, divisa com Ubatuba. As microbacias monitoradas apresentaram taxas evaporativas da ordem de $30 \%$, com conseqüente produção hídrica de $70 \%$ da precipitação média anual. $\mathrm{Na}$ bacia do Rio Grande, a estimativa anual de evapotranspiração potencial foi de $1.050 \mathrm{~mm}$ e a estimativa anual do deflúvio foi $1.941 \mathrm{~mm}$, o que representa taxas evaporativas de $39,5 \%$ e de produção hídrica na ordem de $73 \%$ do total da chuva que chega à bacia.

Outros estudos foram conduzidos também no Parque Estadual da Serra do Mar em Cunha por Cicco et al. (1985), para determinar a taxa de escoamento anual básico. Foi estimado que o escoamento básico anual representa $50,9 \%$ da precipitação anual e $72 \%$ do escoamento total anual, ou seja, aproximadamente $51 \%$ da precipitação anual escoa em forma de escoamento básico. Para a bacia do Rio Grande, foi estimado que o escoamento básico contribui com $44 \%$ da precipitação anual e $60 \%$ do escoamento total anual. 
Tabela 5. Série gerada de vazões médias mensais $\left(\mathrm{m}^{3} / \mathrm{s}\right)$ para o Rio Grande de Ubatuba (1935 a 2001)

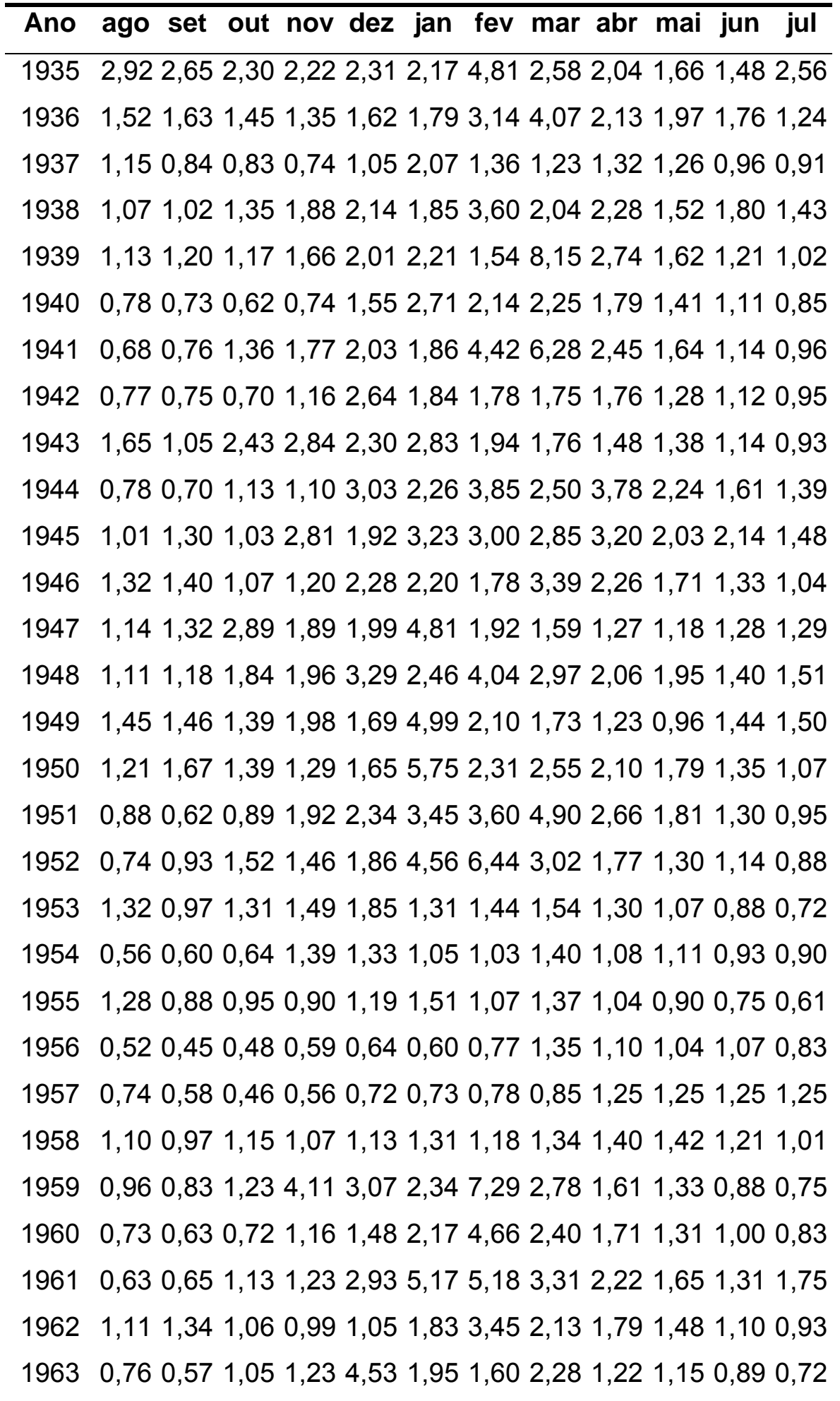


Tabela 5. Série gerada de vazões médias mensais $\left(\mathrm{m}^{3} / \mathrm{s}\right)$ para o Rio Grande de Ubatuba (1935 a 2001)

\begin{tabular}{|c|c|}
\hline Ano & ago set out nov dez jan fev mar abr mai jun ju \\
\hline 1965 & $0,820,991,211,812,112,442,132,122,38$ 2,25 1,78 1,55 \\
\hline 1966 & 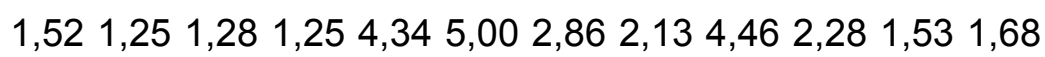 \\
\hline 1967 & $1,121,401,831,923,214,703,969,473,11$ 1,65 1,17 0,91 \\
\hline 1968 & 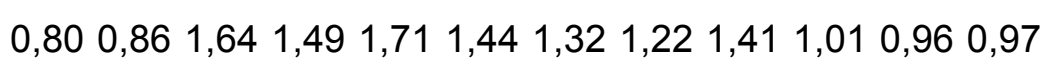 \\
\hline 1969 & 0,91 0,86 1,22 1,09 1,57 2,152,50 1,95 1,68 1,36 1,18 1,04 \\
\hline 1970 & $0,910,831,094,642,652,172,301,851,421,141,170,98$ \\
\hline 1971 & $1,421,131,28$ \\
\hline 1972 & $0,901,110,931,191,851,341,711,401,390,990,840,64$ \\
\hline 1973 & $0,520,811,361,441,503,392,231,691,431,721,142,09$ \\
\hline 1974 & $1,261,291,312,163,123,941,891,481,060,810,660,58$ \\
\hline 1975 & $0,490,490,470,511,012,272,461,651,441,270,960,84$ \\
\hline 1976 & $0,811,111,412,672,404,833,072,501,98$ 1,81 1,32 1,25 \\
\hline 1977 & $1,271,081,450,83$ \\
\hline 1978 & $0,570,450,530,781,401,931,921,561,411,140,930,75$ \\
\hline 1979 & $0,640,730,590,841,121,471,193,692,031,481,190,99$ \\
\hline 1980 & $0,890,740,701,092,693,092,641,831,861,201,050,79$ \\
\hline 1981 & 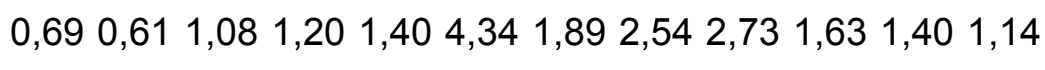 \\
\hline 1982 & $0,971,050,951,591,971,971,572,381,651,241,170,89$ \\
\hline 1983 & $0,741,031,081,752,251,761,592,271,982,111,791,39$ \\
\hline 1984 & $1,230,980,950,841,361,441,081,170,980,890,700,65$ \\
\hline 1985 & $0,530,570,611$ \\
\hline 1986 & $0,920,960,731,281,261,133,142,982$ \\
\hline 1987 & 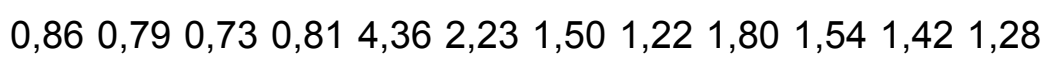 \\
\hline 1988 & $1,001,121,261,271,511,624,122,242,111,751,451,15$ \\
\hline 1989 & $0,951,091,091,041,501,451,442,361,521,301,541,33$ \\
\hline 1990 & $\begin{array}{lllllllllllllll}1,17 & 1,12 & 1,11 & 1,27 & 1,20 & 1,02 & 0,86 & 1,03 & 1,35 & 1,07 & 0,98 & 0,89\end{array}$ \\
\hline 1991 & $0,720,761,491,171,281,531,663,041,771,551,161,00$ \\
\hline 1992 & $0,781,150,961,050,983,071,361,160,971,530,850,17$ \\
\hline 1993 & $0,780,961,332,601,871,902,243,061,911,531,341,00$ \\
\hline
\end{tabular}


Tabela 5. Série gerada de vazões médias mensais $\left(\mathrm{m}^{3} / \mathrm{s}\right)$ para o Rio Grande de Ubatuba (1935 a 2001)

\begin{tabular}{llllllllllllllll}
\hline Ano & ago & set & out nov dez jan & fev mar abr mai & jun & jul \\
\hline 1994 & 0,84 & 0,94 & 0,78 & 0,81 & 1,04 & 1,37 & 1,65 & 2,65 & 3,03 & 1,82 & 1,71 & 1,28 \\
1995 & 1,23 & 1,19 & 1,81 & 1,50 & 1,39 & 1,84 & 2,33 & 2,48 & 1,68 & 1,46 & 1,28 & 1,06 \\
1996 & 0,91 & 1,22 & 1,69 & 1,78 & 1,93 & 2,45 & 7,89 & 3,45 & 1,94 & 1,47 & 1,18 & 0,93 \\
1998 & 0,51 & 0,42 & 0,39 & 0,61 & 0,96 & 2,42 & 1,74 & 2,15 & 3,60 & 3,42 & 2,23 & 1,93 \\
1999 & 1,40 & 1,43 & 2,09 & 1,72 & 1,61 & 1,52 & 1,70 & 1,54 & 1,63 & 1,19 & 1,17 & 1,03 \\
2000 & 0,87 & 0,94 & 1,38 & 1,08 & 1,74 & 2,06 & 1,86 & 1,93 & 1,37 & 1,09 & 0,83 & 0,64 \\
2001 & 0,55 & 0,64 & 0,71 & 1,13 & 1,64 & 1,60 & 1,40 & 1,36 & 1,08 & 1,06 & 0,85 & 0,85
\end{tabular}

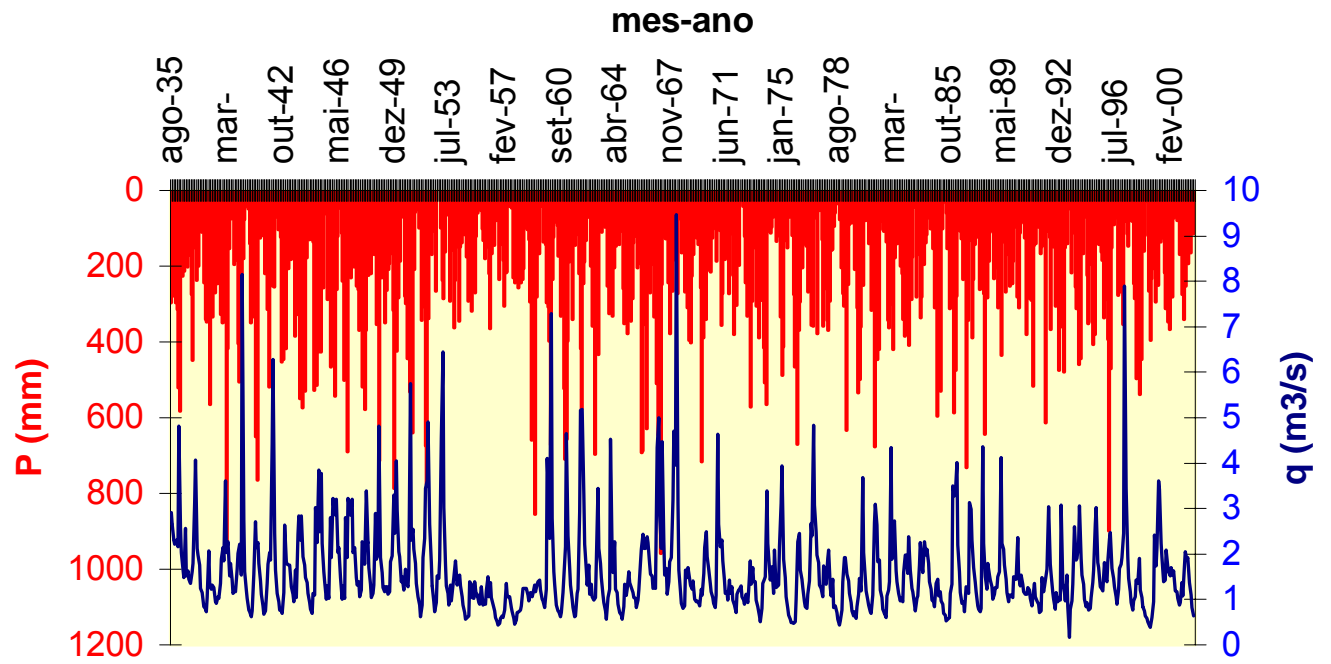

Figura 23 - Série histórica para a relação chuva - vazão gerada pelo Modelo SMAP, para o período de agosto de 1935 a julho de 2001 


\section{DISCUSSÃO}

\subsection{Vazão ecológica}

Para analisar o balanço entre a demanda e a disponibilidade de água na bacia do Rio Grande de Ubatuba, o primeiro passo foi estimar a vazão mínima ou vazão ecológica, uma vez que se considera como vazão disponível de um rio aquela resultante da diferença entre a vazão atual e a vazão mínima.

A vazão ecológica é definida na Instrução Normativa 04 de 21 de junho de 2000 do Ministério do Meio Ambiente como a "vazão mínima necessária para garantir a preservação do equilíbrio natural e a sustentabilidade dos ecossistemas aquáticos" (Brasil, 2000a).

A legislação brasileira não estabelece critérios quantitativos nem qualitativos de vazão que deve ser garantida à jusante de uma captação de água, para que se mantenha a condição ecológica de um rio. 0 estabelecimento desses critérios deve ser feito através dos Planos de Recursos Hídricos Regionais.

Um trabalho pioneiro para determinação da vazão ecológica foi realizado por Pelissari et al.(2000), que utilizaram uma metodologia baseada na aptidão das espécies de peixes para as diferentes condições de habitat físico presentes no rio. Segundo os autores, este é o primeiro trabalho no país que leva em consideração o ecossistema aquático, em particular a ictiofauna.

Para a estimativa da vazão ecológica, no caso de outorga de uso da água, normalmente adota-se uma vazão de referência dos corpos d'água. Os Estados de São Paulo, Paraná e Minas Gerais usam como vazão de referência o Q7,10, que corresponde à vazão média mínima de sete dias cons€ 
com período de retorno de dez anos na seção do corpo d'água. Os Estados do Ceará, Bahia e Paraná usam o Q90, que corresponde à vazão com garantia de $90 \%$ de permanência.

É importante salientar que a vazão de referência NÃO representa necessariamente a vazão mínima ou vazão ecológica. Como o próprio nome diz, aquela vazão serve para balizar a estimativa da vazão mínima ou vazão ecológica, conforme pode ser observado na Quadro 9.

\begin{tabular}{|c|c|c|}
\hline Estado & Vazão de referência & Vazão ecológica ou mínima \\
\hline Ceará & Q 90 & 9/10 da vazão de referência \\
\hline Bahia & Q 90 & $\begin{array}{c}80 \% \text { da vazão de referência ou } 95 \% \text { nos } \\
\text { casos de abastecimento urbano }\end{array}$ \\
\hline Paraná & Q 7,10 & $50 \%$ da vazão de referência \\
\hline São Paulo & Q 7,10 & $\begin{array}{l}\text { Análise caso a caso } \\
\text { Alguns técnicos adotam } 50 \% \text { da vazão de } \\
\text { referência }\end{array}$ \\
\hline Minas Gerais & Q 7,10 & $30 \%$ da vazão de referência \\
\hline Pernambuco & Q 90 & $\begin{array}{c}10 \% \text { da vazão de referência por razão } \\
\text { ecológica }\end{array}$ \\
\hline
\end{tabular}

Fonte: Azevedo, et.al (2003)

Quadro 9 - Vazão de referência utilizada para outorga de água

No presente estudo, foi adotado como vazão ecológica o próprio Q7,10, e o seu valor foi estimado utilizando-se o Método de Regionalização Hidrológica do Estado de São Paulo do Departamento de Águas de Energia Elétrica (DAEE,1988), disponível na rede mundial de computadores - internet. Para tal estimativa, usaram-se as coordenadas geográficas (UTM) do ponto de captação que é 487824 Km E e 7412722 Km W e a área de drenagem da bacia correspondente a $26 \mathrm{Km}^{2}$, obtendo, assim, como valor de referência, : de $0,449 \mathrm{~m}^{3} / \mathrm{s}$. (http://www.sigrh.sp.gov.br). 


\subsection{Balanço entre disponibilidade $X$ demanda}

Consideram-se, como disponibilidade de água, para a bacia do Rio Grande, as vazões médias mensais estimadas pelo modelo SMAP, após a subtração da vazão mínima ecológica.

Embora a captação de água para abastecimento público no Rio Grande de Ubatuba tenha começado em 1998, partiu-se da premissa de que com a série histórica gerada, pode-se inferir sobre o potencial e os riscos do manancial, para o abastecimento público ou ainda para a manutenção dos processos ecológicos. Cabe destacar que o fato da bacia permanecer ainda em boas condições de cobertura florestal resulta numa melhor previsão do potencial e riscos.

Quanto à demanda de água, a mesma foi calculada com base no volume de água que é captada pela concessionária de abastecimento público de água, que é a Companhia de Abastecimento de Água do Estado de São Paulo (SABESP).

De acordo com as informações que constam no documento "Diagnóstico da Situação Atual dos Recursos Hídricos da Unidade de Gerenciamento dos Recursos Hídricos do Litoral Norte - Relatório Final" (IPT,2000) do Comitê de Bacias Hidrográfica do Litoral Norte, o volume de água que é captado na bacia do Rio Grande no verão é de $0,598 \mathrm{~m}^{3} / \mathrm{s}$ e no inverno é de $0,234 \mathrm{~m}^{3} / \mathrm{s}$, conforme apresentado no Quadro 10. 


\begin{tabular}{|c|c|c|c|c|c|c|}
\hline \multirow{2}{*}{ Sistema } & \multirow{2}{*}{ Manancial } & \multicolumn{2}{|c|}{ Coordenadas ( UTM) } & \multirow{2}{*}{$\begin{array}{l}\text { Área de drenagem } \\
\qquad\left(\mathrm{Km}^{2}\right)\end{array}$} & \multicolumn{2}{|c|}{$\operatorname{Vaz} 6 \operatorname{es}\left(\mathrm{m}^{3} / \mathrm{s}\right)$} \\
\hline & & $\mathrm{kmE}$ & $\mathrm{km} \mathrm{W}$ & & Verăo & Inverno \\
\hline Picinguaba ** & $\begin{array}{c}\text { Afluente da margem } \\
\text { esquerda do Rio } \\
\text { Picinguaba }\end{array}$ & $\mathrm{nd}^{*}$ & $\mathrm{nd}^{*}$ & 1,0 & 0,023 & 0,009 \\
\hline Fazenda ** & "sem nome" & $\mathrm{nd}^{*}$ & nd $^{*}$ & 1,4 & 0.032 & 0.012 \\
\hline Almada e Engenho ${ }^{* *}$ & "sem nome" & nd $^{*}$ & nd* & 1,4 & 0,032 & 0,012 \\
\hline Ubatumirim *t & "sem nome" & $\mathrm{nd}^{*}$ & $\mathrm{nd}^{*}$ & 1,9 & 0,043 & 0,016 \\
\hline Puruba $*$ & "sem nome" & $\mathrm{nd}^{*}$ & $\mathrm{nd}^{*}$ & $\mathrm{nd}^{*}$ & $\mathrm{nd}^{*}$ & $\mathrm{nd}^{*}$ \\
\hline Prumirim ** & "sem nome" & $\mathrm{nd}^{*}$ & $\mathrm{nd}^{\star}$ & 1,0 & 0.023 & 0.009 \\
\hline Félix ${ }^{\star \star}$ & "sem nome" & $\mathrm{nd}^{*}$ & $\mathrm{nd}^{*}$ & 0,4 & 0,008 & 0,003 \\
\hline Itamambuca * & "sem nome" & 500862 & 7412892 & 1,2 & 0.028 & 0,011 \\
\hline \multirow{2}{*}{ Ubatuba * } & $\begin{array}{l}\text { Rio Comprido } \\
\text { (Macacos) }\end{array}$ & 486140 & 7409447 & $\mathrm{nd}^{*}$ & $\mathrm{nd}^{*}$ & $n d^{*}$ \\
\hline & Rio Grande cota 37,5 & 487824 & 7412722 & 26,0 & 0,598 & 0,234 \\
\hline $\begin{array}{c}\text { Dura, Corcovado, } \\
\text { Folha Seca e Rio } \\
\text { Escuro } * * / * * * \\
\end{array}$ & $\begin{array}{c}\text { Rio da Cachoeira do } \\
\text { Gato - Cota } 116 \text { m }\end{array}$ & nd* & $\mathrm{nd}^{*}$ & 5,3 & 0,087 & 0,072 \\
\hline \multirow{2}{*}{ Vermelha do Sul * } & "sem nome" & 481922 & 7399604 & $\mathrm{nd}^{*}$ & $\mathrm{nd}^{*}$ & nd* \\
\hline & "sem nome" & 482039 & 7399362 & nd & nd* & nd" \\
\hline Maranduba ** & $\begin{array}{c}\text { Afluente margem } \\
\text { esquerda Rio } \\
\text { Maranduba } \\
\end{array}$ & 473713 & 7397832 & 0.006 & 0.143 & 0,056 \\
\hline \multirow[t]{2}{*}{ Maranduba $* *$} & Ribeirăo Lagoinha & $n d^{*}$ & $n d^{*}$ & 2.9 & 0.066 & 0.026 \\
\hline & & & & Total & 1,083 & 0,460 \\
\hline
\end{tabular}

Fonte : SABESP $(1999,2000)$

Vazóes especificas ( minimas médias de 7 dias consecutivos, com período de retorno de 10 anos ou garantia de $90 \%$ )

Essas vazôes especificas são aplicáveis sem restriçōes a bacias hidrográficas da Serra do Mar, na regiấo objeto do estudo, cujas áreas estejam situadas no intervalo de 2 a $12 \mathrm{Km}^{2}$.

Para áreas inferiores a $2 \mathrm{Km}^{2}$ devem ser empregadas com cautela, pois as caracteristicas locais, em uma área tāo restrita, podem alterar substancialmente os valores das vazóes mínimas.

* Operados pela SABESP

* Reforçol Proposta

** Projeto

nd" - informaçâo nâo disponivel

Quadro 10 - Captações superficiais para o abastecimento público de Ubatuba

É importante notar que o quadro acima apresenta 2 valores de captação de água, sendo $0,598 \mathrm{~m}^{3} / \mathrm{s}$ considerada como captação no verão e $0,234 \mathrm{~m}^{3} / \mathrm{s}$ como a captação no inverno. Para efeitos deste trabalho, levando em consideração a sazonalidade populacional, considerou-se a captação de 0,558 $\mathrm{m}^{3} / \mathrm{s}$ para os meses de alta temporada (dezembro, janeiro e fevereiro), portanto, para os demais meses, a captação considerada seria de $0,234 \mathrm{~m}^{3} / \mathrm{s}$.

A partir dessas informações pode-se gerar as Figuras 24, 25 e 26 que relacionam a disponibilidade hídrica (diferença entre as vazões estimadas e a vazão ecológica) com a demanda atual (vazão da água captada). Foram apresentados os balanços disponibilidade $X$ demanda para: a) a série histórica gerada; b) para o ano hídrico mais seco da série gerada (1955-1956) e c) para o ano hídrico mais chuvoso (1966-1967), respectivamente. 
$\mathrm{Na}$ análise da serie histórica gerada nota-se que existe grande disponibilidade de água nos meses de janeiro, fevereiro e março, ocorrendo uma diminuição nos meses junho, julho agosto e setembro, com tendência de igualar a demanda de água.

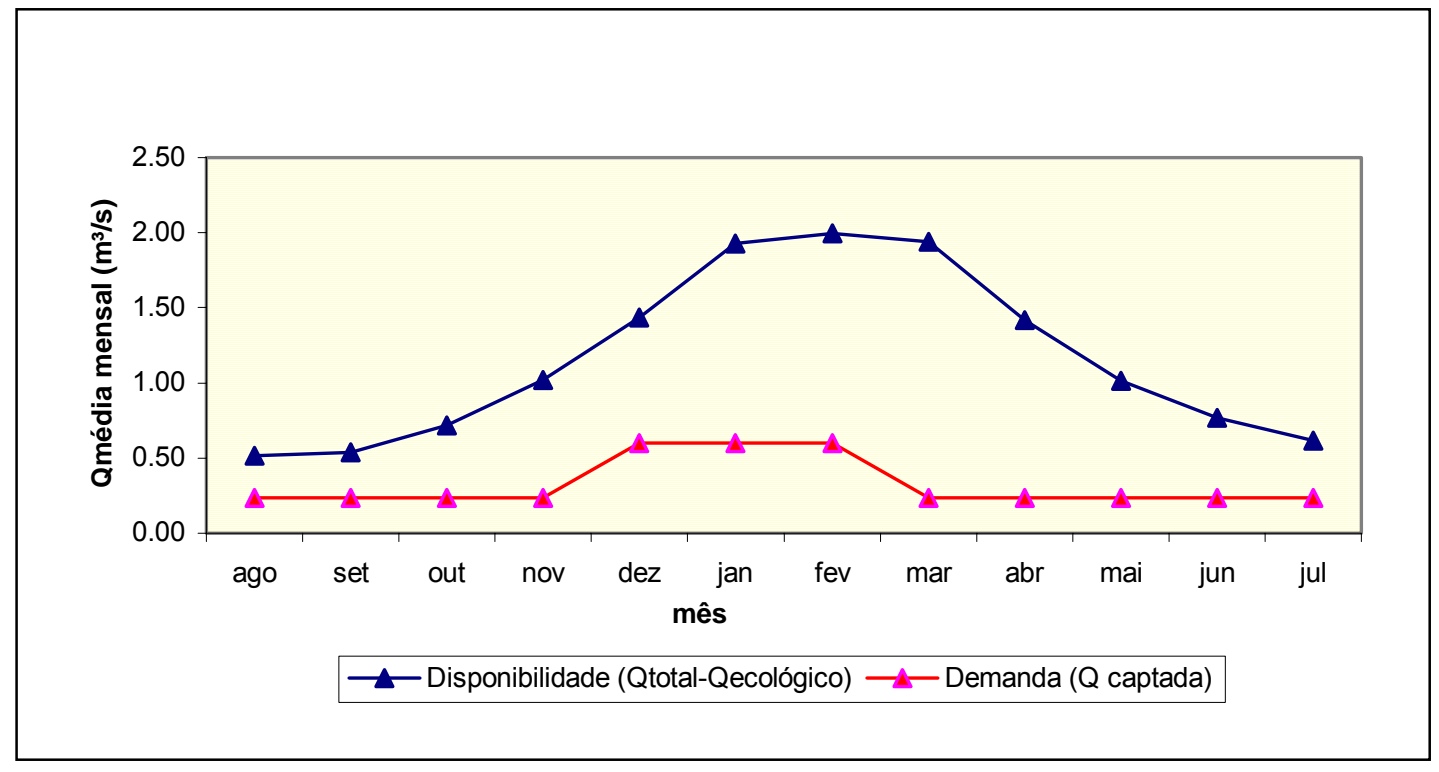

Figura 24 - Demanda de água atual na bacia e disponibilidade de água, considerando as vazões medias na série histórica para o período de 1935 a 2001

Observa-se que no ano hídrico mais seco da série histórica, ocorrido no período de agosto de 1955 a junho de 1956, os meses de agosto, setembro, outubro, novembro, dezembro, janeiro e fevereiro apresentaram disponibilidade hídrica menor que a demanda, conforme Figura 24. 


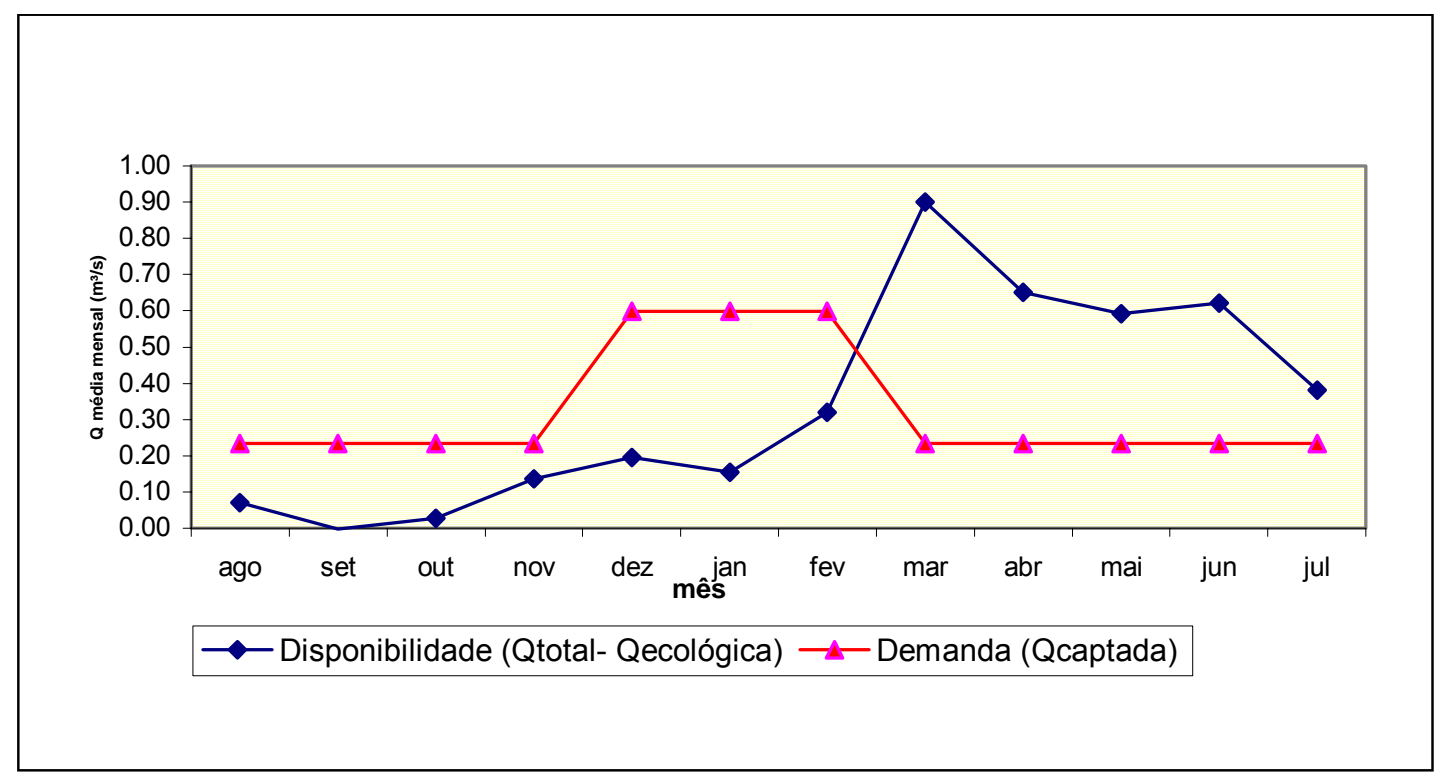

Figura 25 - Demanda de água atual na bacia e disponibilidade de água considerando as vazões medias no ano hídrico mais seco (1955-1956) encontrada na série histórica gerada para o período de 1935 a 2001

Porém, mesmo no ano hídrico mais chuvoso, ocorrido no período de agosto de 1966 a julho de 1967, a disponibilidade hídrica praticamente se iguala com a demanda durante os meses de junho, julho, agosto e setembro (Figura 26). 


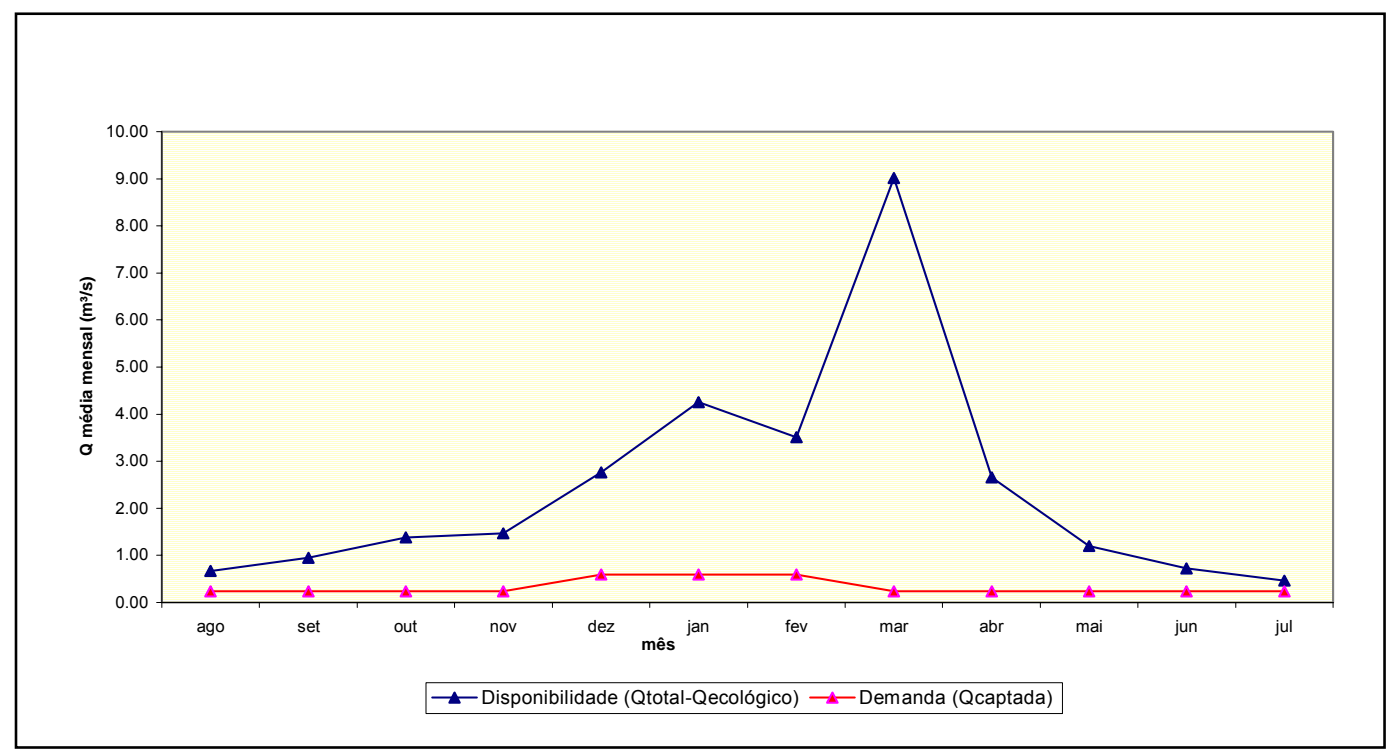

Figura 26 - Demanda de água atual na bacia e disponibilidade de água considerando as vazões medias no ano hídrico mais chuvoso (1966-1967) encontrado na série histórica gerada para o período de 1935 a 2001

Determinou-se também o percentual de meses da série histórica nos quais a demanda de água é maior ou menor que a disponibilidade hídrica. Neste caso, também foi considerada, para o período de dezembro a fevereiro a vazão captada no manancial, que é de $0,598 \mathrm{~m}^{3} / \mathrm{s}$, considerando o aumento da população que ocorre na alta temporada turística e, para o período de março a novembro, considerou-se como vazão captada $0,234 \mathrm{~m}^{3} / \mathrm{s}$.

Para isso foi calculada a vazão demandada, que corresponde a vazão captada para abastecimento público somada à vazão ecológica, ou seja, o Q7,10.

Os resultados mostram que a demanda foi maior que a disponibilidade hídrica em $6,5 \%$ dos meses no primeiro período (dezembro a fevereiro) e $8,1 \%$ dos meses para o segundo período (março a novembro). 
Com isso, pode-se inferir que, em aproximadamente $7,7 \%$ dos meses da série de vazão gerada, ocorre déficit de água ou para abastecimento público ou para atender a demanda ecológica, conforme apresentado no Quadro 11.

\begin{tabular}{|c|l|c|cc|}
\hline Período & $\begin{array}{c}\text { Vazão demandada } \\
\text { (demanda + vazão } \\
\text { ecológica) }\end{array}$ & $\begin{array}{c}\text { Qdisp* >Qdem** } \\
\text { (No. de meses) }\end{array}$ & $\begin{array}{c}\text { Qdisp <Qdem } \\
\text { (No. de meses) }\end{array}$ \\
\hline $\begin{array}{c}\text { dezembro } \\
\text { a } \\
\text { fevereiro }\end{array}$ & $\begin{array}{c}\text { Vazão demandada (Qdem) } \\
=1.047 \mathrm{~m} 3 / \mathrm{s}\end{array}$ & 201 & 13 & $6,5 \%$ \\
\hline $\begin{array}{c}\text { março } \\
\mathbf{a}\end{array}$ & $\begin{array}{l}\text { Vazão demandada (Qdem) } \\
\text { novembro }\end{array}$ & $5965 \mathrm{~m} 3 / \mathrm{s}$ & & 48 \\
\hline \\
Total
\end{tabular}

$\left(^{*}\right)$ Qdisp = vazão total - vazão ecológica

$\left.{ }^{* *}\right) \mathrm{Q}$ dem = vazão captada

Quadro 11 - Número de meses em que a demanda é maior ou menor que a disponibilidade de água para abastecimento e o porcentual de meses que a disponibilidade é menor que a demanda

A Figura 27 mostra os meses que apresentaram vazão excedente ou com déficit de água. Os meses em que os picos se encontram abaixo da linha vermelha representam o déficit hídrico. 


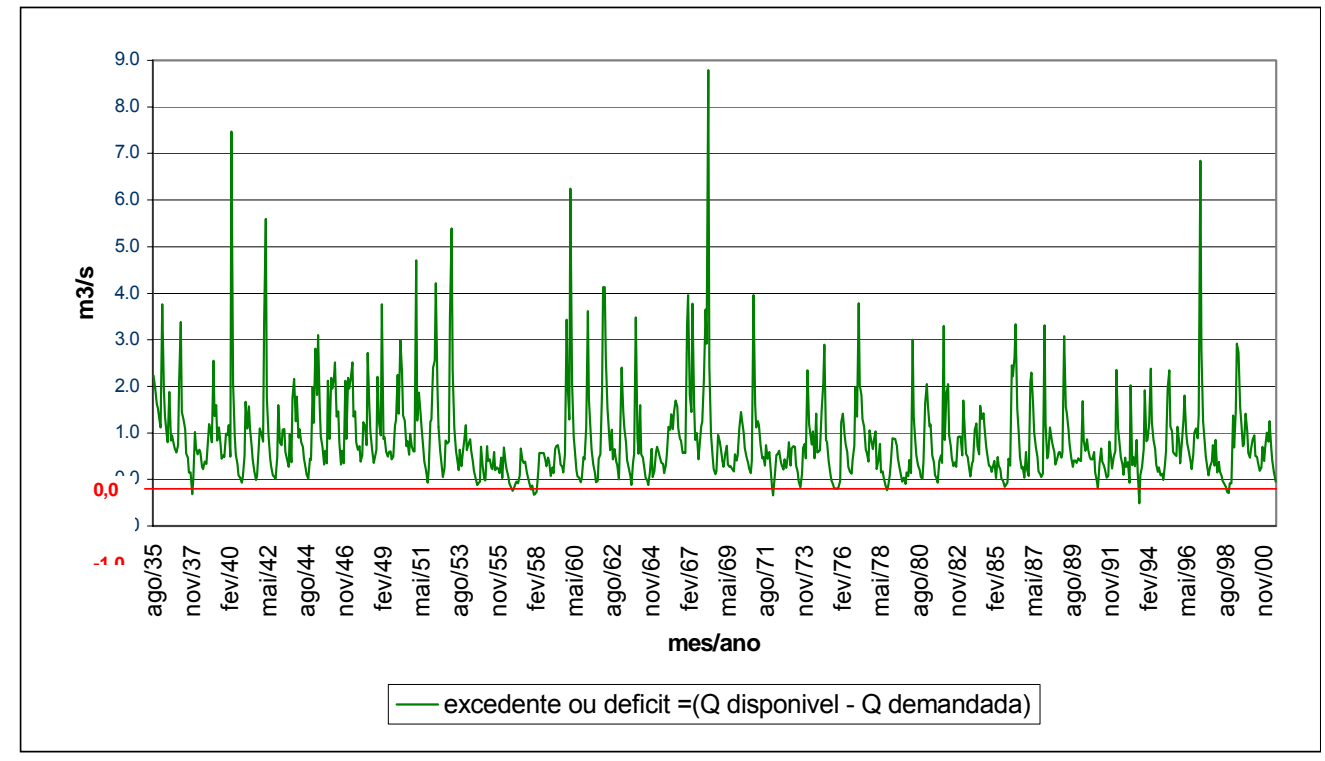

Figura 27 - Meses com vazão excedente ou com déficit hídrico para o período de 1935 a 2001

\subsection{Sazonalidade da população}

Uma peculiaridade do município de Ubatuba é a reduzida população residente e elevado fluxo sazonal, o que implica em alternância de ociosidade e sobrecarga no sistema de abastecimento público.

Como não existem dados estatísticos sistematizados sobre a população flutuante, adotaram-se os critérios estabelecidos no Plano de Gerenciamento dos Recursos Hídricos do Litoral Norte do Comitê de Bacias Hidrográfica do Litoral Norte (IPT,2001), sendo que, na baixa temporada, admite-se um incremento populacional de até 3 vezes; e na alta temporada, coincidindo com o período de verão, ocorre um incremento de até 6 vezes da população fixa, que está em torno de 71.000 habitantes. 
Para avaliar a quantidade de água disponível para atendimento da demanda da população foram analisados:

1) a relação entre disponibilidade de água, em termos médios mensais, e a demanda de água, para abastecimento público, considerando a sazonalidade da população abastecida pelo manancial;

2) a relação entre disponibilidade de água em um ano seco, e a demanda de água para abastecimento público, considerando a sazonalidade da população abastecida pelo manancial; e

3) o mesmo que o item anterior, porém considerando um ano chuvoso.

Os sistemas de abastecimento público em Ubatuba recobrem $87 \%$ da população. Da população abastecida com água tratada, $88 \%$ recebem água que é captada no Rio Grande. Assim, estima-se que, atualmente 55.000 pessoas consomem água proveniente desta bacia. Nos finais de semana ou feriados prolongados, estima-se um crescimento no número de consumidores de água para 163.000 pessoas, e na alta temporada, 326.000 pessoas (Quadro 12). 


\begin{tabular}{|l|r|}
\hline & $\begin{array}{l}\text { Número de } \\
\text { pessoas }\end{array}$ \\
\hline População de Ubatuba* $^{*}$ & 71.000 \\
\hline População residente que recebe água tratada de sistema público** & 62.000 \\
\hline População residente que recebe água captada no RGU*** & 55.0000 \\
\hline $\begin{array}{l}\text { População estimada em feriados e finais de semana que recebe } \\
\text { água tratada do RGU**** }\end{array}$ & 163.000 \\
\hline $\begin{array}{l}\text { População estimada na temporada que recebe água tratada do } \\
\text { RGU***** }\end{array}$ & 326.000 \\
\hline
\end{tabular}

${ }^{*}$ Censo 2000 (IBGE)

** $87 \%$ da população residente recebe água tratada de sistema publico

*** Do total da população que é abastecida pelo sistema público, $88 \%$ são provenientes do Rio Grande.

**** aumento de 3 vezes a população residente (IPT 2001b)

**** aumento de 6 vezes a população residente(IPT, 2001 b)

Quadro 12 - Estimativa da população de Ubatuba abastecida pelo Rio Grande de Ubatuba

Para estimar a água disponível para o abastecimento público, subtraiu-se da vazão media mensal estimada a vazão mínima (ecológica), com o propósito de garantir uma vazão mínima suficiente para não comprometer os processos ecológicos no Rio Grande de Ubatuba .

Considerando o dado básico de consumo de água per capta de 200 litros por dia e adicionando-se a perda no sistema de distribuição de água que é de aproximadamente 40\% (IPT,2001), pôde-se então estimar a população que pode ser atendida pelo manancial, com uma demanda de 280 litros por pessoa por dia (consumo básico + perdas).

E assim podem-se construir 3 diferentes quadros: o Quadro 13, que traz tal estimativa considerando a media das vazões encontradas na serie histórica, o Quadro 14, que traz as mesmas análises, porem considerando o ano hídrico 
mais chuvoso da série gerada (1966-1967), e o Quadro 15, com os dados referentes ao ano hídrico mais seco (1955-1956) da série gerada. 


\begin{tabular}{|c|c|c|c|c|c|c|c|c|c|c|c|c|}
\hline Mês & ago & set & out & nov & dez & Jan & fev & mar & abr & mai & jun & jul \\
\hline Q média & 0.97 & 0.98 & 1.16 & 1.47 & 1.88 & 2.38 & 2.45 & 2.39 & 1.87 & 1.46 & 1.22 & 1.07 \\
\hline Q ecológica & 0.449 & 0.449 & 0.449 & 0.449 & 0.449 & 0.449 & 0.449 & 0.449 & 0.449 & 0.449 & 0.449 & 0.449 \\
\hline Q disponível & 0.521 & 0.531 & 0.711 & 1.021 & 1.431 & 1.931 & 2.001 & 1.941 & 1.421 & 1.011 & 0.771 & 0.621 \\
\hline $\begin{array}{l}\text { População que pode ser } \\
\text { atendida }\end{array}$ & 160766 & 163851 & 219394 & 315051 & 441566 & 595851 & 617451 & 598937 & 438480 & 311966 & 237909 & 191623 \\
\hline
\end{tabular}

Quadro 13 - Vazão média mensal ( $\left.\mathrm{m}^{3} / \mathrm{s}\right)$, vazão média mensal disponível $\left(\mathrm{m}^{3} / \mathrm{s}\right)$, população máxima (habitantes /dia) que pode ser atendida

\begin{tabular}{|c|c|c|c|c|c|c|c|c|c|c|c|c|}
\hline Mês & ago & set & out & nov & dez & jan & fev & mar & $a b r$ & mai & jun & jul \\
\hline Q média & 1.52 & 1.25 & 1.28 & 1.25 & 4.34 & 5 & 2.86 & 2.13 & 4.46 & 2.28 & 1.53 & 1.68 \\
\hline Q ecológica & 0.449 & 0.449 & 0.449 & 0.449 & 0.449 & 0.449 & 0.449 & 0.449 & 0.449 & 0.449 & 0.449 & 0.449 \\
\hline Q disponível & 1.071 & 0.801 & 0.831 & 0.801 & 3.891 & 4.551 & 2.411 & 1.681 & 4.011 & 1.831 & 1.081 & 1.231 \\
\hline População que pode ser atendida & 330480 & 247166 & 256423 & 247166 & 1200651 & 1404309 & 743966 & 518709 & 1237680 & 564994 & 333566 & 379851 \\
\hline
\end{tabular}

Quadro 14 - Vazão média mensal $\left(\mathrm{m}^{3} / \mathrm{s}\right)$, vazão média mensal disponível $\left(\mathrm{m}^{3} / \mathrm{s}\right)$, população máxima (habitantes /dia) que pode ser atendida. (Ano mais chuvoso da série - 1966-1967)

\begin{tabular}{|c|c|c|c|c|c|c|c|c|c|c|c|c|}
\hline Mês & ago & set & out & nov & dez & jan & fev & mar & $a b r$ & mai & jun & jul \\
\hline Q média & 1.28 & 0.88 & 0.95 & 0.9 & 1.19 & 1.51 & 1.07 & 1.37 & 1.04 & 0.9 & 0.75 & 0.61 \\
\hline Q ecológica & 0.449 & 0.449 & 0.449 & 0.449 & 0.449 & 0.449 & 0.449 & 0.449 & 0.449 & 0.449 & 0.449 & 0.449 \\
\hline Q disponível & 0.831 & 0.431 & 0.501 & 0.451 & 0.741 & 1.061 & 0.621 & 0.921 & 0.591 & 0.451 & 0.301 & 0.161 \\
\hline População que pode ser atendida & 256423 & 132994 & 154594 & 139166 & 228651 & 327394 & 191623 & 284194 & 182366 & 139166 & 92880 & 49680 \\
\hline
\end{tabular}

Quadro 15 - Vazão média mensal $\left(\mathrm{m}^{3} / \mathrm{s}\right)$, vazão média disponível $\left(\mathrm{m}^{3} / \mathrm{s}\right)$, população máxima (habitantes /dia) que pode ser atendida (Ano mais seco da série - 1955-1956) 
Esses resultados mostram que, na alta temporada, época de grande flutuação de população, a demanda de água pode ser superior à disponibilidade hídrica do manancial.

Essas evidências de análise temporal do balanço entre a disponibilidade e demanda de água para abastecimento público da bacia hidrográfica permitiram inferir que poderão ocorrer problemas de falta de água para manutenção dos processos ecológicos do manancial, ou mesmo para abastecimento público, considerando três aspectos: a flutuação da população, a ocorrência de anos hídricos secos e, mesmo nos anos hídricos normais, ocorrência de períodos de meses secos prolongados.

Essa tendência evidencia que, com o índice pluviométrico da região e mesmo mantendo boas condições de cobertura florestal na bacia, é necessário fazer um planejamento de uso da água.

Destaca-se que o Sistema ETA - Carolina foi projetado para atender do bairro do Lázaro ao bairro de Itamambuca, até o ano de 2006. Atualmente o sistema opera sem atender todos os bairros nos quais foram projetados. Sendo o manancial Rio Grande o principal contribuinte, poderá o sistema operar com sobrexploração de água,

É notável a existência de grande disponibilidade de água no manancial, mas é importante pensar em alternativas de captação e distribuição de água para suprir a demanda de abastecimento público considerando esses aspectos sazonais.

Outro fato que merece ser discutido é o do conceito de bacia crítica. $\mathrm{O}$ artigo 14 da Lei Estadual n 9.034, de 27 de dezembro de 1994 que dispõe sobre o Plano Estadual de Recursos Hídricos, preconiza que:

"... Art. 14. Quando a soma das vazões captadas em uma determinada bacia hidrográfica, ou em parte desta, superar $50 \%$ (cinqüenta por cento) da respectiva vazão de referência, a mesma será considerada crítica e haverá gerenciamento especial que levará em conta: 
I - o monitoramento da quantidade e da qualidade dos recursos hídricos, de forma a permitir previsões que orientem o racionamento ou medidas especiais de controle de derivações de águas e de lançamento de efluentes;

II - a constituição de comissões de usuários, supervisionadas pelas entidades estaduais de gestão dos recursos hídricos, para o estabelecimento, em comum acordo, de regras de operação das captações e lançamentos;

III - a obrigatoriedade de implantação, pelos usuários, de programas de racionalização do uso de recursos hídricos, com metas estabelecidas pelos atos de outorga..."

Com base nesse instrumento legal analisou-se a criticidade da bacia, à partir do ponto de captação de água para abastecimento publico $\left(26 \mathrm{Km}^{2}\right)$.

Ressalta-se que acima do ponto captação de água para abastecimento público, não existem dados sobre eventuais lançamentos ou sobre a quantidade de água que está sendo captada para atender a comunidade que mora a montante e que não recebe água tratada pelo sistema.

Sendo a vazão de referência igual a 0,449 m3/s no local, a criticidade da bacia hidrográfica é de 52,11\%, no período de março a novembro (fora da alta temporada) e $133,18 \%$ no período de dezembro a fevereiro (alta temporada).

Essa análise foi efetuada para "parte da bacia", todavia, o Diagnóstico da Situação Atual dos Recursos Hídricos da Unidade de Gerenciamento dos Recursos Hídricos do Litoral Norte - Relatório Final (IPT, 2000), realizou a análise para a área total da bacia que é de 102,6 $\mathrm{Km}^{2}$ e estimou a criticidade de apenas $2 \%$. 


\section{CONCLUSÕES}

A bacia do Rio Grande de Ubatuba, assim como várias outras bacias brasileiras, não possuem monitoramento de dados hidrológicos. O uso do modelo SMAP foi adequado, pois com apenas três anos de dados completos de vazões monitorados, foi possível calibrar os parâmetros da bacia e validar o modelo, encontrando-se uma correlação de 0,838 podendo, assim, gerar a série histórica. Pela sua simplicidade e de fácil manejo, o Modelo SMAP pode se constituir em uma ferramenta bastante útil para estudos similares em outras bacias.

Com a série histórica gerada, permitiu-se analisar a disponibilidade de água na bacia, levando em consideração a sazonalidade da população abastecida pelo manancial. Devido às características inerentes das cidades litorâneas que recebem um grande aporte de turistas na temporada e finais de semanas, como é o caso de Ubatuba, essa flutuação de população nem sempre é considerada na análise do balanço entre a demanda e a disponibilidade hídrica.

O estudo mostra que a partir do ponto de captação, a bacia do Rio Grande é considerada crítica por apresentar comprometimento de $52 \%$ no período fora da temporada e de $133 \%$ na alta temporada, o que torna necessária a implantação de algumas medidas de monitoramento para orientar o racionamento e o controle de derivações e lançamento de efluentes no corpo d'água. Essa análise pontual nem sempre é feita nos planos de bacias regionais e um exemplo disso é o próprio estudo realizado para balizar o Plano de Bacia 
do Litoral Norte que apresenta a bacia do Rio Grande com índice de criticidade de apenas $2 \%$.

Essas informações poderão subsidiar na elaboração e implantação do Plano de Manejo participativo para a bacia do Rio Grande de Ubatuba.

\subsection{Recomendações}

Com a taxa de crescimento populacional de 3,9\% ao ano é possível inferir que a demanda de água aumentará, e a disponibilidade hídrica da bacia tende a ficar mais crítica.

A retirada de água do manancial sem um planejamento adequado pode comprometer os processos ecológicos bem como a capacidade de autodepuração no caso de diluição de efluentes que são lançados em outros trechos do Rio Grande de Ubatuba.

Como recomendação para o Plano de Manejo participativo para a bacia hidrográfica, o monitoramento diário da quantidade de água que passa no vertedor na área de captação é uma das medidas necessárias para o estabelecimento de regra de operação para a captação de água manancial, de racionalização de uso e de controle de perdas na rede de distribuição.

Outras medidas recomendadas e algumas já abarcadas nas matrizes de Planejamento do Plano de Manejo da Bacia são:

a) controle e fiscalização das derivações de água do Rio Grande e de seus afluentes;

b) implantação de sistema de abastecimento de água para a comunidade moradora à montante da captação de água;

c) controle e fiscalização de novas ocupações irregulares a montante da captação de água;

d) implantação de programa de fiscalização da cobertura florestal, priorizando as áreas consideradas de preservação permanente definidas no artigo $2^{\circ}$ da Lei 4.771/65 (Brasil,1965) alterada pela Lei 7803/89 
(Brasil, 1989) - Código Florestal - combinado com a Resolução CONAMA 303/2002 (Brasil, 2002), e também das áreas de proteção integral, abrangida pelo Parque Estadual da Serra do Mar;

e) programa de redução de perda no sistema de distribuição de água que atualmente é de $40 \%$;

f) busca de fontes alternativas para distribuição de águas em outros bairros;

g) campanhas educativas de conscientização da população fixa e flutuante sobre a necessidade da preservação deste manancial que é estratégico para o município de Ubatuba. 


\section{REFERÊNCIAS BIBLIOGRÁFICAS}

ANIDO N.M.R. Caracterização hidrológica de uma bacia experimental visando identificar indicadores de monitoramento ambiental. Piracicaba, 2002. 69p. Dissertação (Mestrado). Escola Superior de Agricultura "Luiz de Queiroz", Universidade de São Paulo.

ARCOVA, F.C.S. Geração do deflúvio em bacias hidrográficas florestais de primeira e segunda ordem. In: CURSO INTERNACIONAL SOBRE MANEJO EM BACIAS HIDROGRÁFICAS, 5. Apostilas. Programa de Treinamento para Terceiros Paises. São Paulo: Instituto Florestal, Japan Internacional Cooperation Agency, ABC,1999. p. 240-275.

ARCOVA, F.C.S.; CICCO, V. Características do deflúvio de duas microbacias hidrográficas no laboratório de hidrologia florestal Walter Emmerich, Cunha SP. Revista Instituto Florestal, v. 9, n.2, p. 153-170, 1997.

ARCOVA, F.C.S; LIMA, W. P.; CICCO, V. Balanço hídrico de duas microbacias hidrográficas no laboratório de hidrologia florestal Walter Emmerich. São Paulo. Revista Instituto Florestal, v. 10 n.1 p. 39-51, 1998.

AZEVEDO, L.G.; BALTAR, A. M.; REGO, M.; PORTO, R. L. L. Sistema de suporte à decisão para outorga de água de direitos de uso da água no Brasil. Brasília: Banco Mundial , 2003. 48p. 
BEVEN, K. J.; GERMANN, P. Macropores and water flow in soils. Water Resources. Resumo v.18, n.5, p. 1311-1325, 1982,

BORMANN, F.H.; LIKENS, G.E. The nutrient cycles of an ecosystem. Scientific American, v.4, p.92-101,1970.

BRASIL. Leis, decretos, etc. Lei $n^{\circ} 4771$ de 15 de setembro de 1965. Diário Oficial da União, 16 set. 1965. Institui o Novo Código Florestal.

BRASIL. Leis, decretos, etc. Decreto no 10251 de 30 de agosto de 1977. Âmbito: Belo Horizonte. CODEX: Coletânea de legislação, nov.2002. Cria o Parque Estadual da Serra do Mar e dá providências correlatas.

BRASIL. Leis, decretos, etc. Decreto no 13313 de 6 de março de 1979. Âmbito: Belo Horizonte. CODEX: Coletânea de legislação, nov.2002. Dá nova redação ao artigo $2 .^{\circ}$ do Decreto $n^{\circ} 10.251$, de 30 de agosto de 1977 , que dispõe sobre a criação do Parque Estadual da Serra do Mar, com a finalidade de incorporar ao seu perímetro área situada na região denominada Picinguaba, $1 .^{\circ}$ perímetro de Ubatuba, conforme Processo SA. $n^{\circ}$ 89.208-77, bem como de retificar sua linha perimétrica entre os pontos P25 e P30, nos termos do Processo S.A. 446-78.

BRASIL. Leis, decretos, etc. Lei $n^{\circ} 7.803$ de 18 de julho de 1989. Âmbito: Belo Horizonte. CODEX: Coletânea de legislação, nov.2002. Altera a lei $n^{\circ}$ 4.771, de 15 de setembro de 1965, e revoga as leis 6535 , de 15 de junho de 1978, e 7511 de 7 de julho de 1986. 
BRASIL. Leis, decretos, etc. Lei n 7663 de 30 de dezembro de 1991. Âmbito: Belo Horizonte. CODEX: Coletânea de legislação, nov.2002. Estabelece normas de orientação à Política Estadual de Recursos Hídricos bem como ao Sistema Integrado de Gerenciamento de Recursos Hídricos.

BRASIL a. Leis, decretos, etc. Decreto Federal $n^{\circ} 750$ de 10 de fevereiro de 1993 Âmbito: Belo Horizonte. CODEX: Coletânea de legislação, nov.2002. Dispõe sobre o corte, a exploração e a supressão de vegetação primária ou nos estágios avançado e médio de regeneração da Mata Atlântica, e dá outras providências. http://www.silex.com.br/leis/dec_750.html . ( 07 dez. 2002).

BRASIL b. Leis, decretos, etc. Resolução do Conselho Nacional do Meio Ambiente $\mathrm{n}^{\circ} 10$ de $1^{\circ}$ de outubro de 1993. Âmbito: Belo Horizonte. CODEX: Coletânea de legislação, nov.2002. Estabelece parâmetros básicos para análise dos estágios de sucessão da Mata Atlântica.

BRASIL Leis, decretos, etc. Resolução n 001, de 31 de janeiro de 1994. Âmbito: Belo Horizonte. CODEX: Coletânea de legislação, nov.2002. Define, para o Estado de São Paulo, vegetação primária e secundária nos estágios pioneiro, inicial, médio e avançado de regeneração de Mata Atlântica, em cumprimento ao disposto no artigo $6^{\circ}$, do Decreto 750 , de 10 de fevereiro de 1993 e na Resolução CONAMA n 10 de 10 de outubro de 1993, a fim de orientar os procedimentos de licenciamento de atividades florestais no Estado. 
BRASIL Leis, decretos, etc. Lei no 9605 de 12 de fevereiro de 1998. . Âmbito: Belo Horizonte. CODEX: Coletânea de legislação, nov.2002. Dispõe sobre as sanções penais e administrativas derivadas de condutas e atividades lesivas ao meio ambiente, e dá outras providências.http://www.planalto.gov.br. (23 nov.2002).

BRASIL a. Instrução Normativa $n^{\circ} 4$ de 21 de junho de 2000 do Ministério do Meio Ambiente. Âmbito: Belo Horizonte. CODEX: Coletânea de legislação, nov.2002. Aprova os procedimentos administrativos para a emissão de outorga de direito de uso de recursos hídricos, em corpos d'água de domínio da União.

BRASIL b. Lei ${ }^{\circ} 9985$ de 18 de julho de 2000. Âmbito: Belo Horizonte. CODEX: Coletânea de legislação, nov.2002. Regulamenta o Art. 225, § $1^{\circ}$, incisos I, II, III e VII da Constituição Federal, institui o Sistema Nacional de Unidades de Conservação da Natureza e dá outras providências.

BUCHIANERI, L. G. C. O adolescer pós-moderno: novos paradigmas na medicina. Assis, 2004, 100p. Dissertação (Mestrado). Faculdade de Ciências e Letras de Assis, Universidade Estadual Paulista "Júlio de Mesquita Filho"

BUCHIANERI, V. C.; ZAKIA, M. J B.; LIMA, W. P. Sustainable watershed management program for the Rio Grande in Ubatuba: a search of solutions for the maintenance of water yield and water quality (compact disc). In:WORLD WATER CONGRESS,11. Madri, 2003. Anais Madri, 2003 : CEDEX, 2003.

CAPRA, F. O . Ponto de mutação. São Paulo: Cultrix, 1992. 447 p. 
CHORLEY, R.J. The hillslope hydrologic cycle. In: KIRKBY, M. J. (Ed). Hillslope ,Hydrology. Chichester :John Wiley, 1978. p.1- 42.

CHOW, V. T; Handbook of Applied Hydrology. New York: McGraw-Hill Book, 1964. 1v.

CICCO, V.; FUJIEDA, M. Deflúvio. In: CURSO INTERNACIONAL SOBRE MANEJO EM BACIAS HIDROGRÁFICAS, 5, São Paulo, 1999. Apostilas. Programa de Treinamento para Terceiros Paises. São Paulo: Instituto Florestal de São Paulo, Japan Internacional Cooperation Agency, ABC,1999. p.198-239.

CICCO, V. ; ARCOVA, F.C.S. ;SHIMOMICHI,P.Y. Estimativa de evapotranspiração em bacia hidrográfica com floresta natural secundaria de Mata Atlântica - SP. Revista do Instituto Florestal de São Paulo, v.1, n.2, p. 43-54, 1989.

CICCO, V. ; EMMERICH, W; FARIA, A J.; FUJIEDA, M. Projeto de Pesquisas hidrológicas em floresta natural na Reserva Estadual de Cunha Determinação do balanço hídrico. In: SEMINÁRIO SOBRE ATUALIDADES E PERSPECTIVAS FLORESTAIS: A INFLUENCIA DAS FLORESTAS NO MANEJO DE BACIAS HIDROGRÁFICAS, 11, Curitiba,1985. Anais. Curitiba, EMBRAPA/PNPF, 1985. p.135-143.

CLEARY, R. W. Águas Subterrâneas. Rio de Janeiro: ABRH/Ed.UFRJ, 1989. v.2 p.293-404.

DE COURSEY, D.G. Mathematical models for nonpoint water pollution control. Journal of Soil and Water Conservation, v. 40, n.5, p. 408-413, set/out. 1985. 
DOOGE, J.C.I. Linear theory of hydrologic system. Technical Bulletin ARS: UD Department of Agriculture, 1973 p.1948.

FUNTOWICZ, S.; RAVETZ, J. Epistemología política: ciencia con la gente. Buenos Aires: Centro Editor de América Latina, 1993. 93 p.

FUNTOWICZ, S.; RAVETZ, J.: Ciência pós-normal e comunidades ampliadas de pares face aos desafios ambientais. História, Ciências, Saúde, Manguinhos,v.4, n.2, p.219-230, jul-out.l1977. http://www.coc.fiocruz.br/ hscience/vol4n2/ab_funtowiczp.html.(03 set 2003).

GOMES, J. C. C. O conceito de paradigma: da ciência para a sociedade. Embrapa, 2003. http://www.cpact.embrapa.br/Noticias/Conceito.htm. (03 set. 2003).

HEWLETT, J.D.; HIBBERT, A. R. Factors affecting the response of small watersheds to precipitation in humid areas. In: INTERNATIONAL SYMPOSIUM ON FOREST. HYDROLOGY. Pennsylvania, 1967 Proceedings.. Pennsylvania State Univ. p. 275-290.

HIBBERT, A.R. Forest treatment effects on water yield. In: SOPPER, W. E.; LULL, H. W. (Ed.). FORESTY HIDROLOGY. New York: Pergamon Press, 1967. p.527-543.

HIBBERT, A.R.; TROENDLE, C. A. Streamfloow generation by variable source area. In: Swank, W.T.; Corssley, J.R. (Ed.) Forest hydrology and ecology at Coweeta. New York: Springer- Verlag, 1988. p. 111-127. 
INSTITUTO BRASILEIRO DE GEOGRAFIA E ESTATISTICA. Região Sudeste do Brasil. Brasília: Secretaria de Planejamento da Presidência da República, 1981. 2. ed., Folha Ubatuba, MI-2770/4, Escala 1:50.000.

INSTITUTO DE PESQUISAS TECNOLÓGICAS. Diagnóstico da situação atual dos recursos hídricos da unidade de gerenciamento dos recursos hídricos do litoral norte. (compact disc). Ubatuba: Comitê de bacias hidrográficas do litoral norte, 2000.

INSTITUTO DE PESQUISAS TECNOLÓGICAS. Plano de gerenciamento de recursos hídricos do litoral norte. (compact disc). Ubatuba:Comitê de bacias hidrográficas do litoral norte, 2001.

KOBIYAMA, M.; GENZ, F. ; MENDIONDO, E. M. Geo-Bio-Hidrologia In: FÓRUM DE GEO - BIO - HIDROLOGIA. - ESTUDO EM VERTENTES E MICROBACIAS HIDROGRÁFICAS.1, Curitiba, 1998. Anais. Curitiba :UFPR,1998. p. 1- 25.

LIMA, W.P. Função hidrológica da mata ciliar. In: SIMPÓSIO SOBRE MATA CILIAR. São Paulo, 1989. Anais. Campinas:Fundação Cargil,1989. p. 2542.

LIMA, W. P. Impacto Ambiental do Eucalipto. São Paulo: Editora da Universidade de São Paulo, 1993. 301 p.

LIMA, W. P. Hidrologia florestal aplicada ao manejo de bacias hidrográficas. São Paulo: Universidade de São Paulo, 1996. 318 p. (Apostila). 
LIMA, W.P.; ZAKIA, M. J. B. Hidrologia de matas ciliares, In: RODRIGUES, Jr.; LEITÃO FILHO, H.F. Matas Ciliares: Conservação e Recuperação. São Paulo: Editora da Universidade de São Paulo, 2000. p. 33-44.

LOPES J. E. G.; BRAGA B. P . F.; CONEJO J. G. L.; SMAP - A simplified hydrologic model, applied modelling in catchment hydrology. Littleton:V.P.Singh,1982. (Water Resourses Publications,1982)

MONTEIRO, C. A. F A dinâmica climática e as chuvas do Estado de São Paulo (estudo geográfico na forma de Atlas). São Paulo: IGEOG-USP, 1973. 126p.

PASSOS, J. R. S. Modelagem e simulação de hidrógrafas .Piracicaba, 1993. 166p. Dissertação (Mestrado). Escola Superior de Agricultura "Luiz de Queiroz", Universidade de São Paulo.

PELISSARI, V.B.; SARMENTO, R.; TEXEIRA, R. L. Vazão Ecológica a ser considerada no licenciamento ambiental dos sistemas de abastecimento de água. In: CONGRESSO INTERNACIONAL DE ENGENHARIA SANITÁRIA E AMBIENTAL. 13, Universidade Federal do Espirito Santos. 3p. http//:www.ufes.Br/ ctjr/outeng/subart/3.html (10 dez 2003)

PETTS, G. E. A perspective on the abiotic processes sustaining the ecological integrity of running waters. Hidrobyologia. v. 422/423, p.15-27,2000.

RIGHETO, A. M. Hidrologia e recursos hídricos. São Carlos: EESC/USP,1998. 840p.

SÃO PAULO (Estado). Secretaria do Meio Ambiente. Gestão Das Águas: 6 anos de percurso. São Paulo: SMA, 1977, 2v. 128p. 
SÃO PAULO (Estado). Secretaria do Meio Ambiente. Planos de Manejo das Unidades de Conservação.Parque Estadual da Serra do Mar, Núcleo Picinguaba. Fase 1 - Plano de Gestão Ambiental, São Paulo: SMA 1998. 183p.

SÃO PAULO (Estado). Secretaria de Recursos Hídricos, Saneamento e Obras, DAEE. Síntese do Relatório de situação do recursos hídricos do Estado de São Paulo. São Paulo, 1999, 53p.

THORNTWAITE, C. W.; MATHER, J.R. The water balance. New Jersey: Drexel Institute of Technology, 1955. 104p. (Publications in Climatology).

TUCCI C .E. M. Modelos Hidrológicos Porto Alegre: UFRGS/ABRH,1998 $669 p$.

TUCCI, C. E. M. Hidrologia, Ciências e Aplicação. Porto Alegre : Ed Universidade/ UFRGS; ABRH, 2002. 943 p.

TUCCI, C. E.; CLARKE, R.T.; Impacto das Mudanças da cobertura vegetal no escoamento: Revisão. In: FÓRUM GEO-BIO- HIDROLOGIA.- ESTUDOS EM VERTENTES E MICROBACIAS HIDROGRÁFICAS.1., Curitiba, 1998. Anais. Curitiba: UFPR, 1988. p.39-49.

VOGELMAN N, H.W. Fog precipitation in the cloud forests of eastern México. BioScience, v.23, n.2, p.96-100, 1973.

WARD, R. On the response to precipation of headstreams in Humid Areas, Journal of Hydrology, v.74, p.171-189,1984. 
ZADROGA, F. The hydrological importance of a Montane cloud forest area of Costa Rica. In: LAL, R; RUSSEL E. W. (Ed.). Tropical Agricultural Hydrology. Chichester: John Wiley, 1981.cap. 2, p. 59-73.

ZAKIA, M. J. B. Identificação e caracterização da zona ripária em uma microbacia experimental: Implicações no manejo de bacias hidrográficas e na recomposição de Florestas. São Carlos, 1998. 98p. Tese (Doutorado) Escola de Engenharia de São Carlos, Universidade de São Paulo. 